\title{
REIT investment decisions : governance, behavior, and sustainability
}

Citation for published version (APA):

Yonder, E. (2013). REIT investment decisions : governance, behavior, and sustainability. [Doctoral Thesis, Maastricht University]. Maastricht University. https://doi.org/10.26481/dis.20130417ey

Document status and date:

Published: 01/01/2013

DOI:

10.26481/dis.20130417ey

Document Version:

Publisher's PDF, also known as Version of record

\section{Please check the document version of this publication:}

- A submitted manuscript is the version of the article upon submission and before peer-review. There can be important differences between the submitted version and the official published version of record.

People interested in the research are advised to contact the author for the final version of the publication, or visit the DOI to the publisher's website.

- The final author version and the galley proof are versions of the publication after peer review.

- The final published version features the final layout of the paper including the volume, issue and page numbers.

Link to publication

\footnotetext{
General rights rights.

- You may freely distribute the URL identifying the publication in the public portal. please follow below link for the End User Agreement:

www.umlib.nl/taverne-license

Take down policy

If you believe that this document breaches copyright please contact us at:

repository@maastrichtuniversity.nl

providing details and we will investigate your claim.
}

Copyright and moral rights for the publications made accessible in the public portal are retained by the authors and/or other copyright owners and it is a condition of accessing publications that users recognise and abide by the legal requirements associated with these

- Users may download and print one copy of any publication from the public portal for the purpose of private study or research.

- You may not further distribute the material or use it for any profit-making activity or commercial gain

If the publication is distributed under the terms of Article $25 \mathrm{fa}$ of the Dutch Copyright Act, indicated by the "Taverne" license above, 


\section{REIT Investment Decisions:}

Governance, Behavior, and Sustainability

Erkan Yönder 
(C) 2013 Erkan Yönder

All rights reserved. No part of this publication may be reproduced, stored in a retrieval system, or transmitted, in any form, or by any means, electronic, mechanical, photocopying, recording or otherwise, without the prior permission in writing from the author.

ISBN 978-605-4738-52-6

Certificate No

Cover Designer

Printing House

Date of Print
13777

Yeliz Gazeloğlu

SAGE Matbaacilık

March 2013

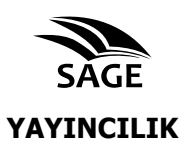

www.sageyayinevi.com

bilgi@sageyayinevi.com 


\section{REIT Investment Decisions: \\ Governance, Behavior, and Sustainability}

\section{DISSERTATION}

to obtain the degree of Doctor at Maastricht University, on the authority of the Rector Magnificus, Prof. dr. L.L.G. Soete, in accordance with the decision of the Board of Deans, to be defended in public

on Wednesday April 17, 2013, at 10:00 hours

by

\section{Erkan Yönder}


Ph.D. Supervisor

Prof.dr. Piet Eichholtz

\section{Co-supervisor}

Dr. Nils Kok

\section{Evaluation Committee}

Prof.dr. Rob Bauer (Chair)

Prof.dr. Jay Hartzell, the University of Texas at Austin, the United States Prof.dr. Frank Moers 


\section{Dedication}

This dissertation is lovingly dedicated to my wife and newborn baby girl! 



\section{Table of Contents}

Acknowledgements............................................................................... 1

Chapter 1 Introduction ........................................................................ 3

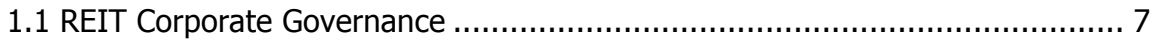

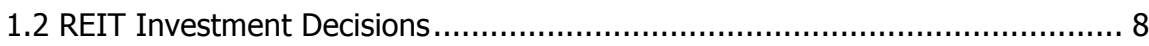

Chapter 2 Real Estate, Governance, and the Global Economic Crisis ......... 13

2.1 Introduction ..............................................................................

2.2 Literature Review.........................................................................

2.3 Data and Descriptive Statistics ......................................................... 18

2.3.1 The Corporate Governance Quotient ........................................... 18

2.3.2 The Crisis: A Structural Break in the Listed Property Market ..................21

2.4 REIT Returns, Corporate Governance, and the Crisis ..............................23

2.4.1 Portfolio Analysis ..................................................................23

2.4.2 Abnormal Returns and the Structure of Corporate Governance ..............26

2.4.3 Abnormal Returns and Ownership Structure...................................31

2.5 Concluding Remarks and Practical Implications .................................33

Chapter 3 CEO Overconfidence, Corporate Investment Activity, and Performance............................................................................................ 41

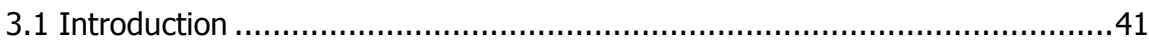

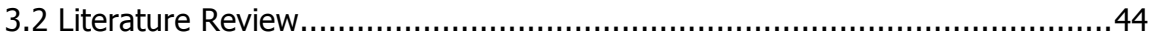

3.3 Data and Method ...................................................................... 47

3.3.1 Measuring CEO investment Decisions ........................................4 47

3.3.2 Measuring CEO Overconfidence .................................................49

3.3.3 Data and Model .....................................................................5

3.4 CEO Overconfidence and Corporate Investment Activity ...........................53

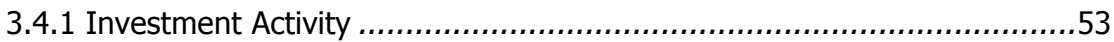

3.4.2 Acquisition and Disposition Activity..........................................56

3.5 CEO Overconfidence and Corporate Performance ..................................62

3.6 Concluding Remarks ................................................................65

Chapter 4 Political Preferences and Corporate Sustainability...................67

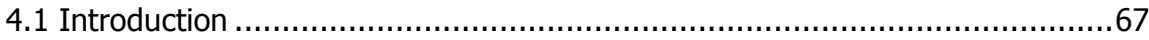

4.2 Literature Review.................................................................69

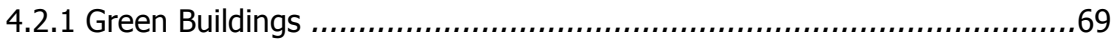

4.2.2 Political Preference and Investment Behavior .................................71

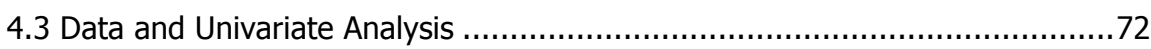

4.3.1 Measuring Portfolio Greenness ............................................... 72

4.3.2 Measuring Political Preferences .................................................. 75

4.3.3 Local Controls..................................................................... 79

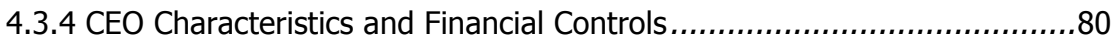

4.4 Methodology and Multivariate Analysis ................................................ 83

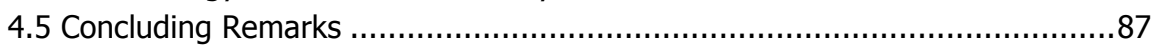


Chapter 5 Portfolio Greenness and the Financial Performance of REITs ... 89

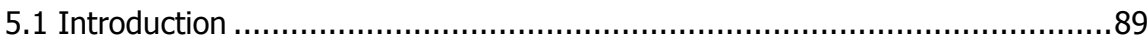

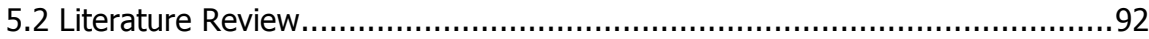

5.2.1 Corporate Social Responsibility and Corporate Financial Performance.....92

5.2.2 The Greenness of REITs and Financial Performance ...........................93

5.3 REITs and Green Buildings ............................................................. 95

5.3.1 Green Building Data ............................................................. 95

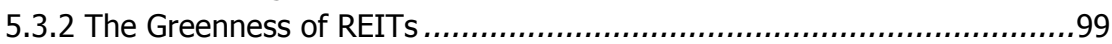

5.3.3 Financial Data...................................................................... 102

5.4 Method and Results .................................................................... 103

5.4.1 Endogeneity Issues ............................................................. 103

5.4.2 The Greenness of REIT Portfolios and Operating Performance.............106

5.4.3 The Greenness of REIT Portfolios and Stock Performance ...................111

5.5 Concluding Remarks .................................................................... 114

Chapter 6 Concluding Remarks, Implications for Practitioners, and Future

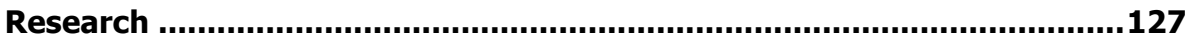

6.1 Concluding Remarks and Practical Implications ................................... 127

6.2 Implications for Future Research................................................... 131

References .............................................................................................133

Samenvatting (Summary in Dutch) .............................................. 141

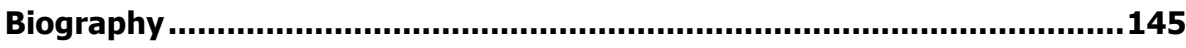




\section{Acknowledgements}

I would like to express my gratitude to those who supported me and shared my four great years in Maastricht to write this dissertation.

The person who put up with me and shared every minute of my experience is my wife who never questioned my decision to go to the Netherlands for Ph.D.. She has always been with me. I am deeply grateful to her. She never gave up on me and showed her love and support in every part of this process. I dedicate all my accomplishments to her and our newborn baby girl, Ece.

I am extremely grateful to my parents, my brother and sister. My parents have always tried to do their best raising me and without them, I would never be where I am now. I also would like to thank my sister and brother who always showed their loyalty and support during my Ph.D. Their visits were the most memorable times of my four years. My nephews and niece, Mehmetcan, Yagiz and Melisa have been my source of inspiration.

I would also like to show my deepest appreciation to my supervisor, Piet Eichholtz. I can now understand how inexperienced I was after the countless things that I have learned from him. He helped me become a different person in all aspects of my professional life. Moreover, he taught me how to become a researcher, he showed me how better communication improves people. I will never forget his morning visits and constant support. He always listened to me and the things I have learned from him became a guide for me in my professional life. I am also very grateful to my cosupervisor, Nils Kok. He has been there since my first day in Maastricht and he has been a friend rather than a supervisor. I love our chats about life as well as extremely productive research talks. I also learned a lot from him. I am very happy to have worked with them and I am eager to write many projects with them in the future, as well. I have no doubt that we will succeed many things together.

I am very grateful to David Geltner for having me as a visiting Ph.D. student at Massachusetts Institute of Technology (MIT) and his support during my job search. I had a great and unforgettable time at MIT and in Boston.

I am grateful to the European Centre for Corporate Engagement (ECCE) and the Department of Finance at Maastricht University for their financial support in order to do research for this dissertation and to present the work in various conferences.

I would like to thank all my former colleagues at the Department of Finance. I enjoyed being a part of the department: Rob Bauer, Jaap Bos, Stefan 
Straetmans, Thies, Sajid, Katie, Michael, Andrea, Gaby, Gildas, Rogier Holtermans, Oana, Aleksander, Paul, Jameel, George, Omar, Nadja Guenster, Jeroen Derwall, Carl, Francien Masthoff, Els Aernsbergen, Cécile van Luijten, Carina van der Velde, Leonard, Mukul, Matteo, Sally, Paulo, Simone and Anna.

Among my friends, I owe most to Semih Akcomak, Burak Can, Birol Yuceoglu and Lei Chen. I made one of the best decisions of my life by sending him the email before meeting him. He opened the door to my life in Maastricht and most importantly, I gained such a great friend. After giving a break for ten years, I am very happy for our reunion with Burak. From the very first days in Maastricht, he has always been with me. I am also thankful to Birol Yuceoglu. He became one of my best friends. He always supported me. I will never forget our ever-lasting coffee breaks with Burak and Birol. Maybe we never saved Turkey and the World but at least, we made an attempt! Lei is one of the people I am most grateful. If I count my best friends, he will be among the few who is on the top of the list. Our talks about life in Maastricht are unforgettable to me. We shared any difficulty of our Ph.D. experience and listened to each other all the time.

I would like to thank my best friends, Utku Unlusayin and Osman Onur Colak. Maybe they weren't in Maastricht with me but have always been there for me for 15 years whenever I needed.

I also want to thank Ingrid Rohde and my Turkish colleagues who made me feel at home, my own country: Evren, Ozge, Devrim, Irem, Mehmet, Emel, Hande and Seher.

I finally thank Robert Brienza for the photograph on the cover of this dissertation. 


\section{Chapter 1 Introduction}

During the last two decades, real estate has been an important investment vehicle in portfolios of pension funds and other institutional investors all over the world. It is the largest alternative investment category (Andonov, Eichholtz and Kok, 2013), and plays an important role as a diversifier in mixed-asset portfolios. Indirect real estate, which is real estate exposure built up through stakes in private and public property companies, is an increasingly important part of these real estate portfolios. As an example, more than 60 percent of the property allocation of Dutch pension funds is through private and/or public property companies. Andonov, Eichholtz, and Kok (2013) provide global evidence using a database of 880 pension funds, and show that REITs are increasingly important for pension funds. In 2009, around 30 percent of the funds in their database invest in REITs.

Investors mainly care about the returns and risks associated with their investments. Size and liquidity are generally secondary considerations, but very important ones, especially when executing a real estate investment strategy. Direct real estate investment can be too large and illiquid for small investors: real estate is capital intensive and can be difficult and time-costly to be disposed of. Additionally, the acquisition and operation of properties requires real estate expertise. Real estate takes a position midway between portfolio investments and entrepreneurial activity, which not always fits well in the culture and business practices of institutional investors.

Indirect real estate investments such as Real Estate Investment Trusts (REITs) help investors to get real estate exposure in their portfolios without these types of problems. An investor can hold even a small amount of shares in a REIT, and acquire well-diversified real estate exposure by combining stakes in different REITs. So especially for smaller investors, they are very practical. Most REITs are listed on stock markets, allowing easy and liquid acquisition and disposal.

As of June 2011, 35 countries had a REIT system (EPRA, 2011). The early introducers were the United States and New Zealand in 1960 and the Netherlands in 1969. Australia has had a REIT system since 1985. In Europe, Belgium has introduced a REIT structure in 1995, while the United Kingdom and Germany have only recently introduced the REIT system in 
2007. Turkey introduced its REIT system in 1995. There has been a wave of REIT system introductions in Asia during the last decade. Examples are Singapore (1999), Japan (2000), South Korea (2001) and Hong Kong (2003).

\section{Figure 1.1}

\section{Total Market Capitalization of REITs by Continents}

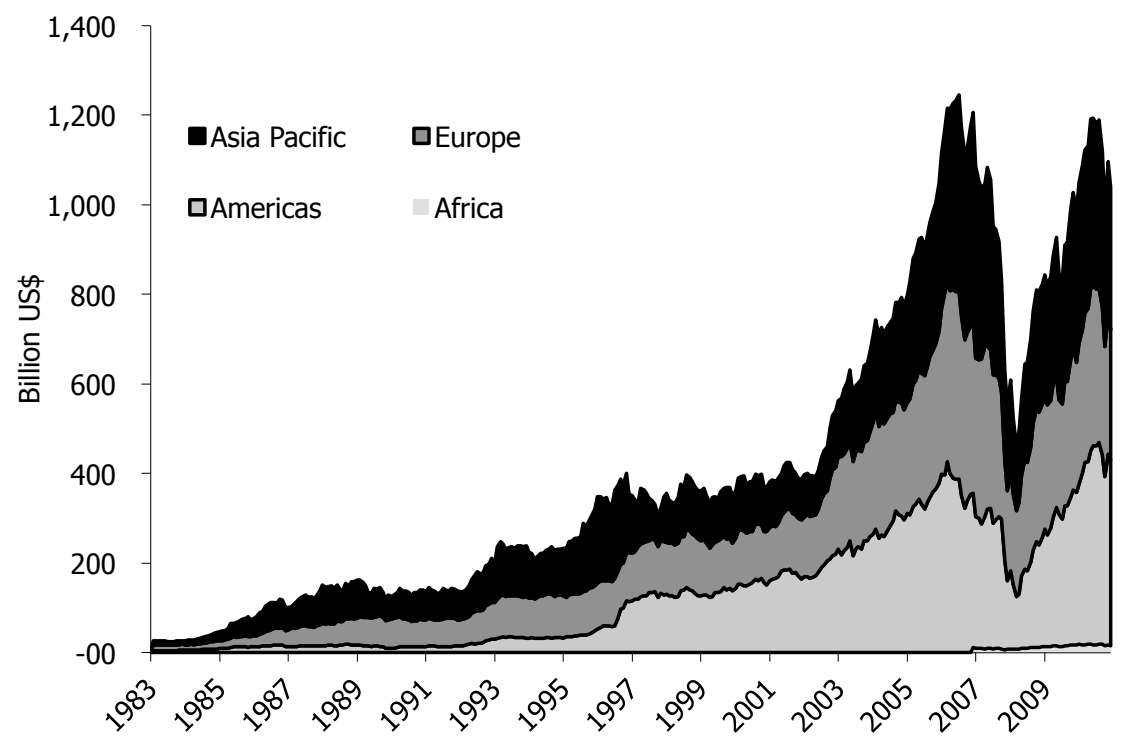

Source: Geltner et al. (2013)

Globally, the total market capitalization of REITs reflects how big and important the REIT industry has become in the global financial markets. Figure 1.1 illustrates this. The total market capitalization of REITs reached a peak in June 2007 with a value of 1,245 billion US dollars. Although that has declined to 461 billion US dollars during the recent global crisis, the global REIT market has been recovering and total market capitalization has increased to 1,039.19 billion US dollars as of November 2011 .

If we evaluate REIT markets by country, the total market capitalization of REITs in the United States is 632 billion US dollars as of June 2012, which is 
way larger than any other country (Ernst and Yong, 2012). The second largest market is the Australian REIT market with a market capitalization of 82 billion US dollars, while the largest European REIT market is in France with a market capitalization of 46 billion dollars. Singapore's REIT market has a market capitalization of 29.86 billion US dollars.

While the transparency and liquidity that REITs bring into real estate make the REIT market attractive, their performance has been quite good. NAREIT reports that U.S. equity REITs have beaten the broad equity market with more than 1 percent per year during the period from January 1978 through December 2010. Their average annual return has been around 12.3 percent for that period. Andonov, Eichholtz and Kok (2013) show that pension funds' REIT investments outperformed their holdings in direct real estate between 1990 and 2009.

REIT regulations are quite similar globally, but there are slight differences between different countries. As this dissertation investigates U.S. REITs, I discuss the regulations that U.S. REITs have to obey. In the United States, REITs are regulated by the U.S. Securities and Exchange Commission (SEC), and provide detailed reports of their activities and performance on a regular basis to report to it. This creates a very high level of transparency. REITs are tax-exempted at the corporate level so that they can avoid double taxation and be competitive to private real estate companies. They are more strictly regulated than regular corporations and have to obey certain rules in order to maintain their REIT status and tax-exemption. The regulations that REITs are subject to can be titled under four categories: ownership, income, assets, and distribution.

The ownership rule states that the five largest REIT shareholders cannot hold more than 50 percent of outstanding shares. Institutional investors such as pension funds are excluded from the "5-50 rule" as they represent the members of their pension plan. Additionally, there must be at least 100 shareholders.

REITs are also restricted in their asset and sources of income. Of their assets, 75 percent must be real estate or real estate related in order to maintain their tax-exempted status. This percentage also holds for their income. Lastly, they have to pay out at least 90 percent of their taxable net income to their shareholders each year. 
Partly because of these legal limitations, REITs have become an important vehicle for researchers in the fields of finance and real estate: the different aspects of the legal setting creates a natural experiment in governance and agency issues. For example, due to the 90 percent payout rule, the discretionary cash available to REIT managers diminishes and the agency problems associated with free cash flows (Jensen, 1886) is lower for REITs than for regular corporations. Due to lower free cash flow in managers' hands, managerial entrenchment becomes more difficult for corporate managers. So the regulatory environment surrounding REITs allows researchers to investigate whether strict rules on free cash flow can affect and replace corporate governance practices to some extent (Bianco, Gosh, and Sirmans, 2007; Bauer, Eichholtz, Kok, 2010a).

Another example of a rule creating a natural experiment is the diversified ownership structure arising from the ownership rule, which impacts merger and acquisition activity. This rule creates two situations. First, with a diversified ownership structure, there is no very strong stakeholder who can influence the decisions of the managers and the investment strategy of the firm and who can benefit at the expense of other shareholders' rights. The second issue is that hostile takeovers are very rare in the REIT industry (Kok and Eichholtz, 2008), diminishing the threat against corporate executives. As a result, internal governance is more of an issue for REITs. Due to these effects, researchers can evaluate the impact of internal governance practices in a more focused and way and can more easily separate these from the effect of external governance using this legal setting.

Additionally, the income and the asset rules limit REITs to invest in real estate and the overall impact is that REITs mainly purchase, operate and sell properties. Due to the SEC's strict reporting rules, these property investments are much better observable compared to the investments made by other types of corporations.

We are able to observe when a REIT makes an investment decision, since we know the date of each property purchase. We can observe how much a REIT spends on each investment decision since we know the transaction price of all the properties they buy and sell. Additionally, we have detailed information on the investment since we know the property characteristics such as address and hedonics of the property. We are also able to observe when a REIT ends an investment or an operation because we also know the 
date of each property sale. Beyond these, REITs are public companies so we know a lot about the company financials and the executives of the company.

As a result, compared to regular corporations, REITs offer a unique laboratory environment for researchers to evaluate investment decisions, which creates all sorts of interesting opportunities for empirical research, of which this thesis explores just a few. The remainder of this introductory chapter provides an overview of the four empirical studies I do based on U.S. REIT data.

\subsection{REIT Corporate Governance}

Previous research has shown that governance is likely to be less important for REITs due to strict rules they have to obey but following Mitton (2002) and Johnson, Moorman, and Sorescu (2009), even in such a restricted legal system, corporate governance might become more important as the expected returns of corporate managers decline and they are possibly more prone to get entrenched during market downturns.

To investigate this issue, I study the effect of the level of corporate governance on REIT stock performance, during the real estate boom and bust of the last decade. My sample covers U.S. equity REITs from 2003 till mid-2009. I divide the sample into two sub-periods considering the real estate investment frenzy from 2003 through 2006 and the recent global crisis during the period between 2007 and mid-2009. The main hypothesis is that investors may not consider corporate governance quality during the investment boom, while governance may become an important issue during the crisis period as investors may reward better governance quality when things go badly.

My findings suggest that investors do not incorporate the strength of corporate governance in the stock prices of REITs, as I find no impact of corporate governance practices on the stock performance of REITs for the pre-crisis period. On the other hand, during the financial crisis, (institutional) investors indeed incorporate information regarding the strength of corporate governance in their investment decision-making process and my results show that better governed companies outperform their worse governed counterparts. 
One of the interpretations of this finding is that (institutional) investors did not incorporate extra-financial information on the corporate governance structure of REITs in their investment decision-making process. I also find a positive impact of institutional ownership on abnormal returns and a convex relationship between the executive ownership and abnormal returns. The result on the real estate holdings of institutional investors suggests that there is a significant influence of institutional owners on indirect real estate markets, even though they do not directly own real estate. In Chapter 2 of this dissertation, I will evaluate this issue and present the findings.

\subsection{REIT Investment Decisions}

The majority of a REIT's business consists of the acquisition, operation, and disposition of property due to the asset and income requirements REITs legally face. As a result, the main decisions made by the management of REITs are relatively easy to observe in principle. In the United States, since all acquisitions and sales have to be reported to the SEC, observing these activities is also possible in practice. This makes REITs special compared to regular corporations, for which it is not always possible to track the specific details of investment decisions by their managers.

\section{Behavioral Issues in Real Estate Investments}

Since the investment decisions of REIT managers can be traced as mentioned above, the factors influencing the decisions of managers can be evaluated using a REIT sample. Managerial overconfidence may be one of those factors.

Overconfidence is one of the most commonly studied behavioral biases. Overconfident people believe that their decisions are superior and will have better outcomes with either higher returns or lower risk or both. In short, they tend to underestimate risk and overestimate expected returns (Benos, 1998; Hirshleifer and Luo, 2001). As a consequence, overconfident investors are likely to trade more frequently.

Following Malmendier and Tate (2005a), the main hypothesis of this study is that an overconfident manager invests more than his non-overconfident 
counterparts. Since I have detailed data on REIT property acquisitions and dispositions, I can evaluate the impact of CEO overconfidence on acquisition and disposition activity, and separately test whether purchasing and selling activities differ in this regard (see also Glaser and Weber, 2007). I measure overconfidence using data on stock option exercise and insider stock trading by the CEOs of REITs.

The results indicate that overconfidence impacts real estate investments. Overconfident REIT managers do indeed invest more than their nonoverconfident counterparts if they have enough discretionary cash. The findings of acquisition and disposition activity separately show that overconfident CEOs purchase more and sell less with appropriate discretionary cash than their non-overconfident counterparts. Overpurchasing and under-selling due to overconfidence lead to suboptimal investment decisions. Accordingly, I find that overconfident CEOs perform worse, so insider stock ownership is indeed a proxy for overconfidence, and not for valuable private information. To my knowledge, this is the first study showing the impact of overconfidence in the real estate markets. It is presented in Chapter 3.

\section{Corporate Sustainability in Real Estate}

Institutional investors incorporate environmental performance, as the environment, climate change and natural resource scarcity have become important issues. The real estate industry plays a crucial role from an environmental perspective, since real estate is shown to account for 40 percent of global greenhouse gas emissions, for 55 percent of the global use of wood, and for about 75 percent of US electricity consumption. In the last two decades, the real estate industry has started focusing on a more efficient use of energy and other resources. In order to increase the environmental efficiency in the real estate markets, several standards and certifications such as LEED and Energy Star have been developed in the United States. In Europe, BREEAM is the leading standard for commercial property. All these labels rate buildings with respect to environmental and energy efficiency performance.

It is important to understand the factors influencing companies to go green. A better understanding of those factors can help policy makers to encourage 
green property investments and institutional investors to judge environmental performance better. I match data on LEED and Energy-Starcertified buildings with detailed information on U.S. REIT property portfolios and calculate the share of green certified properties with LEED or Energy Star certifications, which I define as "portfolio greenness" for each REIT over the 2000-2011 period.

As an initial attempt, I evaluate the factors influencing green property investments. More specifically, my main research question is related to the impact of the political preferences of REIT managers on portfolio greenness. I also investigate the effect of financial and local factors.

I hypothesize that REITs of which the CEOs contribute more to Democrats during Federal Elections are likely to have higher portfolio greenness than Republican-oriented managers. My main hypothesis is based on two ideas. First, Democrats are more prone to follow environmental policies (Hong and Kostovetsky, 2012) and secondly, Republicans tend to more conservative, and are more reluctant to make risky investments in general (Hutton, Jiang, and Kumar, 2011). This creates a relative dislike of new types of investment, probably including investments in green properties.

I collect data on the contributions of REIT CEOs to candidates during federal elections to determine whether a CEO is Democrat- or Republican-oriented. I find that Democrat-leaning (Republican) CEOs are more (less) likely to have high portfolio greenness as measured by the presence of buildings with Energy Star labels. I do not find a relation between the political preferences of a REIT CEO and portfolio greenness measured by LEED labels. These findings contribute to the public discussion of LEED and Energy Star certifications.

My findings also indicate that firm size and the locational greenness of a property significantly influence portfolio greenness, and so does CEO experience. The REITS led by more experienced CEOs are more likely to have higher portfolio greenness. Chapter 4 provides this study of the drivers of green property investments.

Real estate investors may prefer to go green if they believe that their green property investments generate better economic returns. Research by Eichholtz, Kok, and Quigley (2010) document that rents are about 5 percent higher for LEED-certified office properties, and some 3 percent higher for 
Energy Star-rated buildings; the reported increments for transaction prices are 11 percent and 19 percent controlling for differences in building quality. Although a bunch of studies such as Fuerst and McAllister (2011), Miller, Spivey, and Florance (2008), and Wiley, Benefield, and Johnson (2010) find similar results, these studies consider just economic benefits, ignoring or not completely implementing the costs to improve the building.

Evaluating the impact of portfolio greenness on the operating and stock performance of REITs gives insight into the outcome of the interplay between the costs and benefits from green property investments. This contributes to the literature and increases our understanding of the net benefit of green property investments.

Considering the oft-discussed endogeneity between environmental and financial performance (Margolis and Walsh, 2003; Orlitzky, Schmidt, and Rynes, 2003), I create two instrumental variables - local greenness and local environmental government policies. Estimating a two-stage regression model, the findings indicate that portfolio greenness is positively related to the operating performance of REITs.

I also evaluate the impact of portfolio greenness on the stock performance of REITs. My results suggest that there is no significant relationship between portfolio greenness and abnormal stock returns. So investors may already incorporate the information on the higher cash flows deriving from investments in more efficient properties into stock prices. Importantly, I also find that higher portfolio greenness is associated with lower market beta, which can be explained by the fact that REITs with higher portfolio greenness are less exposed to energy price fluctuations and are less prone to occupancy risks (Eichholtz, Kok, and Quigley, 2010). Chapter 5 of this dissertation studies how green property investments affect the operating and stock performance of REITs considering causality issues between corporate social responsibility and financial performance.

The final chapter concludes and summarizes the main findings of this dissertation. I also discuss implications for (institutional) investors and possible future research based on this dissertation. 


\section{Chapter 2 \\ Real Estate, Governance, and the Global Economic Crisis $^{1}$}

\subsection{Introduction}

The real estate sector has played an important role in the current economic crisis. Investors' bullish perspectives regarding the residential and commercial property markets not only allowed borrowers access to cheap and almost unlimited credit, but also offered the possibility to raise large amounts of equity on the public capital markets. However, when the property boom eventually came to an end, this changed the situation with regard to these investments rapidly and fundamentally.

In retrospect, the recent crisis is to a large extent a governance crisis, in which the lack of transparency of securitized products, such as Mortgage Based Securities (MBSs), Collateralized Mortgage Based Securities (CMBSs) and Collateralized Debt Obligations (CDOs) played a crucial role. However, this lack of transparency seems to be mostly associated with the securitized debt products that have been created to finance real estate investments. On the real estate equity side, transparency seems to be less of a problem, thanks to the global rise of the Real Estate Investment Trust (REIT) (see Eichholtz and Kok, 2007).

This REIT market has become of major importance for institutional investors. The REIT structure was primarily created as an avenue for retail investors to gain exposure to (commercial) real estate investments. In the last two decades, however, institutional investors in many countries have shifted their property exposure from direct real estate holdings into listed and private property companies. As a result, REITs have become the key vehicle for real estate investments of institutional investors, who are now the dominant holders of REIT shares. For example, more than 60 percent of

\footnotetext{
${ }^{1}$ This chapter is based on Eichholtz, Piet; Nils Kok and Erkan Yönder. 2011. Real Estate, Governance, and the Global Economic Crisis. University of Pennsylvania Press.

${ }^{2}$ The increasing recognition of corporate governance as a driver of firm value could explain the contrasting results between early studies on corporate governance and performance, and those studies published more recently. However, alternative explanations for the results of Gompers, Ishii, and Metrick (2003) are risk and the investment environment surrounding the market, thereby influencing stock returns.

${ }^{3}$ See http://www.issproxy.com for a detailed description of the Corporate Governance Quotient and its underlying scoring system.
} 
the property allocation of Dutch pension funds is now invested through private or public property companies.

With property investments mostly allocated to intermediate property vehicles, the governance structures of these vehicles are of real importance to key players in the global capital market -- pension funds and insurance companies. The governance structures and their implications for the performance of equity investments in real property are difficult to observe in the market for private funds, but the listed property sector offers a laboratory as to how real estate capital providers integrate and evaluate corporate governance in real estate investment decisions.

Interestingly, where many papers have shown the importance of firm-level governance for common equity investments, the evidence shows that governance has less influence on the performance of REITs, according to Bauer, Eichholtz, and Kok (2010a). The distinct legal setting and organizational structure of REITs - U.S. law requires a 90 percent mandatory payout of net earnings - fundamentally changes the traditional principal-agent setting. The free cash flow problem is of less concern for REIT investors, as the legal distribution requirement limits the opportunities for managerial entrenchment. (Jensen, 1986) Thus, the restricted setting in which managers of REITs operate offers an interesting natural experiment to test the relationship between governance and performance. Under the substitution hypothesis, the legal restrictions that apply to REITs mitigate the need for strong firm-level corporate governance mechanisms according to La Porta et al. (2000). Governance may therefore be less important to investors. On the other hand, REIT managers can freely decide on how to use the free cash flow that remains after the mandatory payout. As the depreciation expense is sizeable for property companies, the discretionary cash flows can still be substantial. Under the complement hypothesis, it can therefore be expected that the relation between corporate governance and performance, which has been documented in the finance literature, holds for U.S. REITs as well.

Moreover, Johnson, Moorman, and Sorescu (2009) show that corporate governance is likely to play a more critical role during the current global financial crisis, as the expected return on investment for managers declines during such crises. As a result, managers may become more entrenched during the crisis, in order to compensate their losses. Rajan and Zingales (1998) have documented how investors shunned away from Asian markets 
at the beginning of the Asian crisis, since the legal environment did not sufficiently protect them from losses and/or downright expropriation. And, the role of institutional ownership may also changes during a crisis: Mitton (2002) finds that institutional ownership positively affected returns during the Asian crisis, which was not the case before the market downturn.

We analyze the impact of the strength of corporate governance on the performance of equity investments in property, during the most recent boom and bust in the real estate market. Our analysis covers U.S. equity REITs, which we study on a yearly basis from 2003 through mid-2009. From 2003 through 2006, the REIT market was booming, and attracted large inflows of capital from both retail and institutional investors. In the real estate frenzy that preceded the current financial crisis, investors may well have invested in REITs, regardless of their governance structure. The investigation for the remaining period - from 2007 through mid-2009 - examines how corporate governance affected stock performance during the market downturn, when well-governed REITs may have had an edge over their less transparent counterparts.

To investigate whether there are significant performance differences between well-governed and poorly governed REITs, we exploit the Corporate Governance Quotient (CGQ) index, provided by Institutional Shareholder Services. First, we perform a two-step cross sectional analysis on the sample of equity REITs. We then replicate the process for two subperiods, in the rising market before the crisis and in the market downturn.

Our results show that the effects of corporate governance on REIT performance differ markedly between the two sub-periods. In the boom period, we do not find any significant relationships between corporate governance structures of real estate equity investments and their abnormal returns. One of the interpretations of this finding is that (institutional) investors did not incorporate extra-financial information on the corporate governance structure of REITs in their investment decision-making process. Contrasting the pre-crisis results, we document that the governance structure of property companies is positively associated with abnormal returns during the downturn, especially where related to board composition and audit quality.

We also address the degree of ownership concentration of institutional investors and executives. We find a convex relationship between abnormal 
returns and the share ownership of executives. Up to a threshold, insider ownership negatively affects stock performance, but above that threshold, stock performance is positively related to insider ownership. Our results also show that the size of shareholdings of block-holders has a positive relationship with abnormal returns. Thus, even though real estate holdings of institutional investors are mostly indirect, large shareholders can still have a direct impact on the performance of their real estate equity investments.

The rest of this chapter is organized as follows: in the next section, we briefly address the literature on corporate governance, performance, and listed property companies. The third section provides an explanation of our main dataset: the ISS corporate governance index. This section also provides the descriptive results of the portfolio analysis, comparing the performance of portfolios of badly governed REITs with those of wellgoverned ones. In the fourth section, we analyze the relationship between corporate governance and equity performance in the light of the changing investment climate surrounding U.S. listed property companies. We investigate the effect of corporate governance determinants on equity performance from a cross-sectional perspective. The chapter ends with conclusions and practical implications for institutional investors and policy makers.

\subsection{Literature Review}

The seminal work of Gompers, Ishii, and Metrick (2003) documents that stock returns are positively related to the structure and strength of corporate governance. An investment strategy that buys a portfolio of well-governed companies, and sells a portfolio of poorly governed companies generates abnormal returns of 8.5 percent. Following this paper, a new stream of literature has emerged, studying different markets and different time periods.

For instance, Drobetz, Schillhofer, and Zimmermann (2004) perform a similar portfolio analysis on German companies. Their investment strategy that takes a long position in companies with high governance quality and a short position in poorly governed companies earns abnormal returns of 12 percent. They explain this finding by unexpected agency costs, the closing of the value gap, and a noise effect. If investors do not identify the corporate 
governance differentials immediately, and they eventually do, this is corrected by paying a premium for well-governed companies. Alternatively, it is possible that correcting a poor governance structure creates value, and consequently causes a value gap between the fair market value and actual market value of companies. The adjusting of stock prices then closes this value gap. Last, there may be a sudden improvement in the governance structure, leading to a noise effect that produces higher stock returns.

The literature regarding the relationship between stock returns and corporate governance for other countries than the U.S. and Germany generates similar findings. Bauer, Guenster, and Otten (2004) find that good governance portfolio returns are higher than returns for bad governance portfolios by around 7 percent for UK companies, but much smaller for similar continental European portfolios. For Japan, Bauer et al. (2008) show that well governed companies exhibit annual excess abnormal returns of up to 15 percent as compared to poorly governed companies.

The governance anomaly seems to be at least partially driven by the ignorance of governance issues by investors during the early days of the bull market in the nineties, as the results disappear in studies using more recent samples (see Core, Guay, and Rusticus, 2006). Indeed, after adjusting firm returns by industry returns, the abnormal returns obtained from the difference portfolio in the 1990s disappear in the analysis of Johnson, Moorman, and Sorescu (2009). ${ }^{2}$

The importance of corporate governance has also been investigated for investments in real estate equities -- or "REITs". To gain their tax-exempt status, REITs are required to generate at least 75 percent of their income from real-estate-related projects and are required to distribute 90 percent of net income to shareholders. However, net income excludes depreciation, which can generate substantial discretionary cash flows for managers of property companies. Additionally, the five largest shareholders cannot hold more than 50 percent of the shares outstanding. These requirements may affect the need for corporate governance structures for REITs, and the

\footnotetext{
${ }^{2}$ The increasing recognition of corporate governance as a driver of firm value could explain the contrasting results between early studies on corporate governance and performance, and those studies published more recently. However, alternative explanations for the results of Gompers, Ishii, and Metrick (2003) are risk and the investment environment surrounding the market, thereby influencing stock returns.
} 
restricted legal setting surrounding REITs makes this market an interesting laboratory for analysis.

Several studies have addressed the distinct governance setting in REITs. Han (2006) investigates the effect of insider ownership on REIT share performance, and finds a positive, but nonlinear relationship. Hartzell, Sun, and Titman (2006) conclude that higher institutional ownership makes REITs more active in exploiting the investment opportunities surrounding them. Ghosh and Sirmans (2003), and Feng, Ghosh and Sirmans (2005) study the impact of board structure on stock performance. Both studies document a positive impact of outside directors on performance. Hartzell, Kallberg, and Liu (2008) analyze corporate governance in the initial public offerings of REITs. They find that REITs with better governance structures at the IPO stage have higher operating performance.

In a paper that is most closely related to this study, Bauer, Eichholtz, and Kok (2010a) test the relationship between corporate governance and operating performance in U.S. REITs, using a broad range of indicators for governance quality. Contrasting the evidence for the general stock market, they do not find a relation between the strength of company-specific corporate governance structures and firm valuation or operating performance. The authors explain the lack of this relationship for REITs as a "REIT effect": REITs operate under such specific legal obligations that managerial freedom is structurally curbed and the agency conflict thereby reduced. However, their analysis is performed in a booming market, and one could argue that investors are less critical with respect to the quality of corporate governance when the market participants are bullish, as the majority of investors in real estate markets were until early 2007. The remainder of this chapter aims to analyze this puzzle in more detail.

\subsection{Data and Descriptive Statistics}

\subsubsection{The Corporate Governance Quotient}

There are several frequently used proxies for the quality of corporate governance. We employ the Corporate Governance Quotient (CGQ) index, provided by Institutional Shareholder Services. The CGQ index is based on publicly disclosed documents and distinguishes 61 different governance 
mechanisms on four sets of items: board of directors, charter and bylaw provisions, anti-takeover provisions, and executive compensation. Using an internal scoring system, ratings are calculated for each company. ${ }^{3}$ What distinguishes the CGQ index from other measures of corporate governance is its relative setting, which ensures cross-sectional variability in the corporate governance scores within an industry.

In addition to the overall governance rating, four different sub-scores are assigned to each company. These sub-scores provide information on four specific governance areas: the board of directors, takeover defences, executive and director compensation and ownership, and auditing. While the overall CGQ index ranges between one and 100, the scores on the four subindices range from one to five. In all cases, a high score represents a governance structure that is favourable to shareholders.

The CGQ database starts in 2002, but we restrict our analysis to the 2003 2009 ratings, as data on sub-indices are not or only partially available before 2003. We only use the governance scores of equity REITs. ${ }^{4}$ We match the list of equity REITs in the CGQ database to the list of constituent companies in the NAREIT Equity index. ${ }^{5}$ This creates an initial equity REIT sample of 144 companies in January 2003, increasing to 152 in 2005, and subsequently decreasing to 112 property companies in May 2009.

We collect data on executive and institutional stock ownership from the SEC proxy statements (item Def 14-A) for each REIT. To obtain financial information, we match the REIT information in the CGQ database with CRSP data on stock prices. After this matching exercise, we end up with 131 publicly traded equity REITs in January 2003, increasing to 139 REITs in 2005, and then falling to 112 REITs by May 2009.

\footnotetext{
${ }^{3}$ See http://www.issproxy.com for a detailed description of the Corporate Governance Quotient and its underlying scoring system.

${ }^{4}$ There are three types of Real Estate Investments Trusts: equity REITs, which purchase, own and manage real estate properties (they may also develop properties); mortgage REITs, which invest in loans secured by real estate; and hybrid REITs, which generate income from rent and capital gains, like an equity REIT, as well as interest, like a mortgage REIT.

${ }^{5}$ The NAREIT Index is the leading benchmark for listed property companies in the Unites States.
} 
Table 2.1

Descriptive Statistics for Governance Scores and Firm Characteristics

\begin{tabular}{|c|c|c|c|c|c|c|c|}
\hline \multicolumn{8}{|c|}{ Panel A. Descriptive Statistics-Annual Averages } \\
\hline & 2003 & 2004 & 2005 & 2006 & 2007 & 2008 & $2009(Q 2)$ \\
\hline CGQ Index & 59.08 & 69.73 & 66.18 & 64.31 & 57.69 & 58.42 & 55.97 \\
\hline Board Index & 3.21 & 3.69 & 3.65 & 3.56 & 3.41 & 3.41 & 3.34 \\
\hline $\begin{array}{l}\text { Compensation } \\
\text { Index }\end{array}$ & 3.82 & 3.86 & 3.66 & 3.64 & 3.31 & 3.42 & 3.26 \\
\hline $\begin{array}{l}\text { Takeover } \\
\text { Defenses Index }\end{array}$ & 2.58 & 3.46 & 3.55 & 3.67 & 3.70 & 2.94 & 3.05 \\
\hline Audit Index & 3.41 & 3.67 & 3.35 & 3.75 & 3.66 & 3.73 & 3.87 \\
\hline $\begin{array}{l}\text { Number of } \\
\text { Equity REITs }\end{array}$ & 131 & 127 & 139 & 133 & 114 & 113 & 112 \\
\hline Size & 1583 & 2160 & 2212 & 2955 & 2502 & 1558 & $1389 *$ \\
\hline Leverage & 50.72 & 51.46 & 53.32 & 52.71 & 54.91 & 55.74 & - \\
\hline \multicolumn{8}{|c|}{ Panel B. Sample Trends } \\
\hline \multicolumn{8}{|c|}{ Removals from the Sample } \\
\hline & 2004 & 2005 & 2006 & 2007 & 2008 & $\begin{array}{l}2009 \\
(Q 2)\end{array}$ & \\
\hline $\begin{array}{l}\text { Number of } \\
\text { Removals }\end{array}$ & 12 & 11 & 16 & 22 & 6 & 1 & \\
\hline \multicolumn{8}{|c|}{ Average Governance Score of Previous Year } \\
\hline CGQ Index & 59.69 & 79.14 & 73.35 & 61.69 & 55.48 & 37.30 & \\
\hline Board Index & 3.50 & 4.27 & 3.94 & 3.59 & 4.00 & 3.00 & \\
\hline Takeover Index & 3.33 & 3.55 & 3.13 & 3.95 & 3.00 & 5.00 & \\
\hline Audit Index & 4.17 & 4.09 & 3.44 & 3.82 & 2.67 & 2.00 & \\
\hline $\begin{array}{l}\text { Compensation } \\
\text { Index }\end{array}$ & 2.67 & 4.55 & 3.94 & 3.18 & 2.50 & 2.00 & \\
\hline \multicolumn{8}{|c|}{ Additions to the Sample } \\
\hline & 2004 & 2005 & 2006 & 2007 & 2008 & $\begin{array}{l}2009 \\
(Q 2)\end{array}$ & \\
\hline $\begin{array}{l}\text { Number of } \\
\text { Additions }\end{array}$ & 8 & 23 & 10 & 3 & 6 & 0 & \\
\hline \multicolumn{8}{|c|}{ Average Governance Score } \\
\hline CGQ Index & 88.85 & 69.93 & 63.88 & 52.50 & 49.32 & - & \\
\hline Board Index & 4.50 & 4.13 & 3.50 & 3.67 & 3.00 & - & \\
\hline Takeover Index & 4.00 & 3.70 & 3.90 & 4.33 & 3.00 & - & \\
\hline Audit Index & 3.88 & 3.17 & 3.70 & 4.33 & 2.33 & - & \\
\hline $\begin{array}{l}\text { Compensation } \\
\text { Index }\end{array}$ & 3.88 & 2.87 & 3.30 & 3.33 & 3.33 & - & \\
\hline
\end{tabular}


Table 2.1 presents the descriptive statistics for the sample of equity REITs. Panel A shows that the average CGQ ratings increase some 10 points from 2003 to 2004. The average governance scores persistently decline afterwards. An explanation may be the privatization of well-governed REITs during that period. During the turn of the market in 2007, the ratings decreased another 7 points.

The subcategories of the governance index in Panel A, governance quality related to board structure and executive compensation, show a downward trend after 2004. Conversely, governance quality related to takeover defenses increases until 2007, but experiences a sharp decline in 2008. This may be a reaction to the high number of acquisitions in 2007: around 20 REITs disappeared from the market. The annual averages for governance practices related to auditing do not show a clear trend before the crisis, but the strength seems to increase during the downturn, which suggests that equity REITs improve their auditing structures. The average leverage ratio is slightly increasing before the crisis, and increases more rapidly with the start of the crisis. This may be explained by the sudden decrease in the market value of assets, relative to a more stable level of debt. ${ }^{6}$

Panel B shows the average governance scores of the companies that are delisted and the companies that are first listed during the sample period. The delistings include REITs that were been acquired, that were voluntarily delisted, or went bankrupt.

We observe that, before the crisis, the average governance score of delisted companies is higher than the average governance score of all REITs in the same year. In other words, well-governed companies were taken private while more poorly governed REITs were floated. However, during the crisis, the situation reverses: delisted companies have CGQ scores that are lower than the annual average of all listed property companies.

\subsubsection{The Crisis: A Structural Break in the Listed Property Market}

The upward trend in the listed property market ended abruptly in early 2007. Figure 2.1 illustrates how the NAREIT Equity index and the S\&P 500

\footnotetext{
${ }^{6}$ Recent market reports have documented price drops of more than forty percent in the largest commercial property markets (New York Times, January 16, 2010).
} 
index performed from January 2003 through June 2009. The cumulative return to the NAREIT Equity index corresponds to 191 percent from January 2003 through January 2007, the top observation in the NAREIT index, while it lost 68 percent from January 2007 through February 2009. In the same time period, the S\&P 500 index increased by 68 percent and then decreased by 49 percent. The figure shows that the NAREIT index experienced sharper upward and downward trends during the sample period as compared to the S\&P 500 index. Moreover, we do not observe a break point in the broader stock market index that is as clear as the break point observed for the property share index.

\section{Figure 2.1}

Time Patterns of the NAREIT Equity Index and S\&P 500 Index

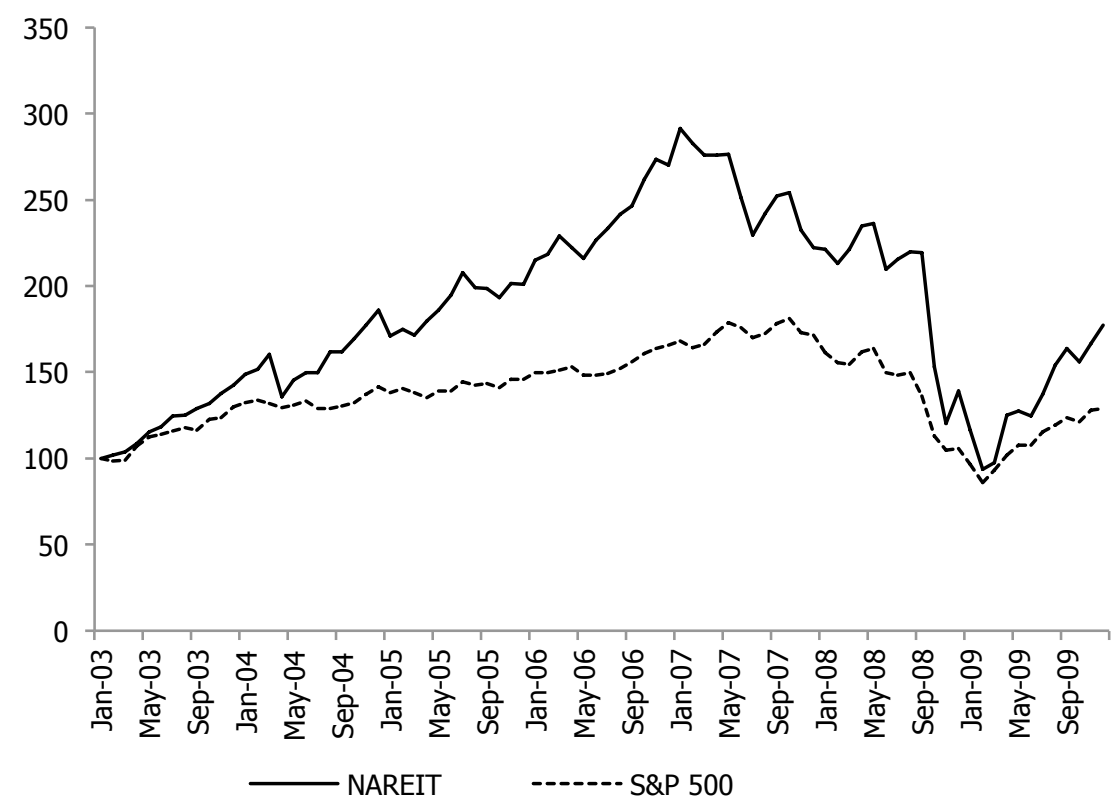

Notes: The time patterns of NAREIT Equity and S\&P 500 indices for the period from January 2003 through December 2009. The beginning of the series are rescaled to 100 .

To determine the beginning and the end of the crisis, we perform an endogenous break point test, as developed by Zivot and Andrews (1992). 
We assume that the structural break occurs in the trend term, since the market moves from an upward sloping trend to a downward sloping one. First, using the NAREIT index from January 2003 to December 2009, we determine the beginning of the crisis, which is February 2007. We then replicate the test from that month to the end of the data set, December 2009, to determine the end of the REIT crisis. The second break point is in May 2009. These breakpoints are consistent with the top observation of the series and the end of the downturn in the market.

\subsection{REIT Returns, Corporate Governance, and the Crisis}

This section provides a detailed investigation of the relationship between REIT returns and the various indexes of corporate governance before and during the financial crisis.

\subsubsection{Portfolio Analysis}

To analyze the impact of corporate governance on REIT equity returns, we construct two mutually exclusive, value weighted equity portfolios: the "Good Governance" portfolio, which includes the companies that represent the top-30 percent of CGQ-rated REITs, and the "Bad Governance" portfolio, which includes the REITs in the bottom 30 percent of CGQ scores. Then, a difference portfolio is constructed by subtracting the monthly return of the bad governance portfolio from the good governance portfolio, which resembles a trading strategy buying stocks with a high governance rating and shorting stocks with a low governance rating. We re-rank the portfolios annually using the year-end datasets published by ISS, and we obtain endof-month value-weighted portfolio returns for 77 months, from January 2003 through May 2009. Companies that no longer appear in the database are excluded.

Panel A of Table 2.2 shows the annual average governance scores of the good governance and the bad governance portfolio. In the rising market (until 2006), we find that the average score of companies in the good governance portfolio is around 89 and relatively stable compared to the average governance score of the companies in the bad governance portfolio. In the market downturn, the average governance rating of the good 
governance portfolio increases to around 91 , again relatively stable within the sub-period.

The annual average CGQ score of the bad governance portfolio is striking, which increases year-by-year during the crisis. It seems like poorly governed companies gradually improved their governance structure after the financial crisis. (However, this could also imply that poorly governed companies may have gone out of business during the crisis.)

\section{Table 2.2}

Sample Statistics Good and Bad Governance Portfolios

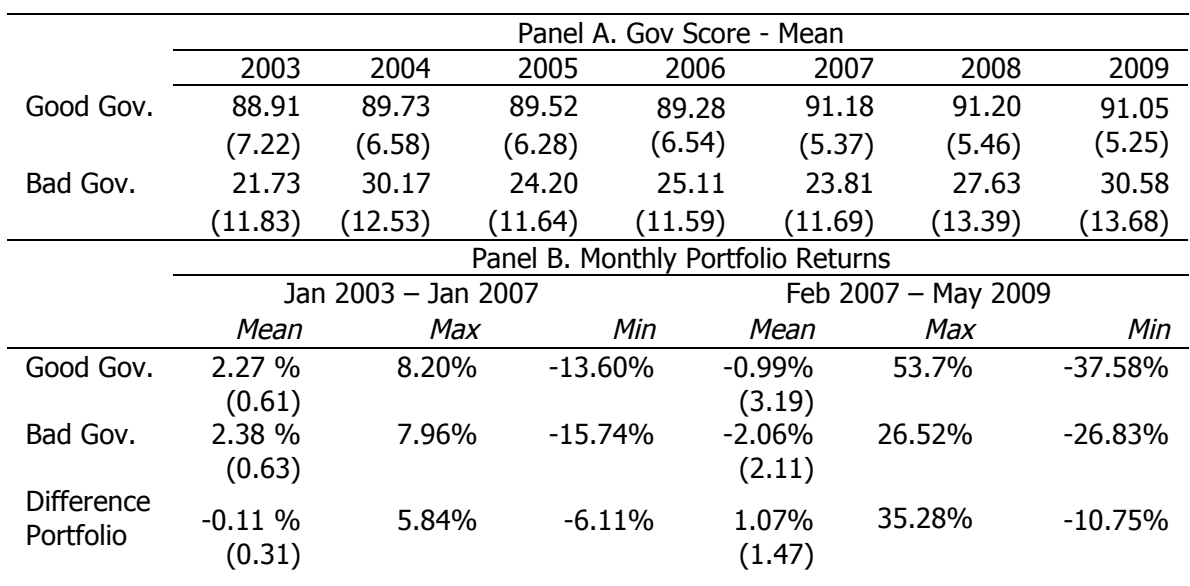

Notes: Table 2.2 presents sample statistics for portfolios of good governed and poorly governed companies using CGQ industry ratings. The difference portfolio is established with a trading strategy that buys the "Good Governance" portfolio and shorts the "Bad Governance" portfolio. The values in parentheses are standard deviations.

Panel B presents some descriptive statistics on the returns of the "Good Governance" and "Bad Governance" portfolio. In the first sub-period, both portfolios generate positive returns, but a trading strategy taking a long position in stocks with a high governance rating and shorting stocks with a low governance rating would not have performed very well, ending up with an average negative monthly return of 0.11 percent. During the crisis, both good governance and bad governance portfolios exhibit negative returns, although the difference portfolio return yields an average positive return of 
1.07 percent. The cross-sectional variation within the good governance portfolio is substantial, and the positive performance of the difference portfolio seems to be driven by a few firms with a very high positive return.

In general, the first descriptive statistics suggest that the change in the economic conditions affects the governance structures of REITs, and the stock returns related to those governance structures.

We further observe the effect of the changing investment climate on the returns of the "good" versus the "bad" governance portfolio in Figure 2.2. The graph shows the annual returns of the respective portfolios. During the rising market, the out performance of the portfolios is mixed, with poorly governed REITs outperforming their better-structured counterparts in some years. However, during the crisis, well-governed companies consistently outperform poorly governed companies, on average.

Figure $\mathbf{2 . 2}$

\section{Annual Average Returns of Governance Portfolios}

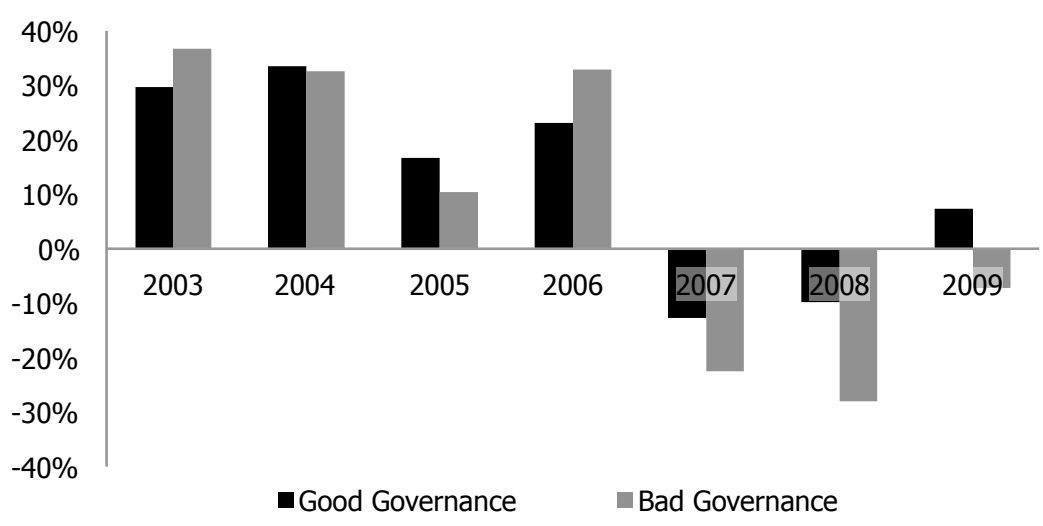

Notes: Figure 2.2 shows the annual average returns of governance portfolios. The "Good Governance" portfolio includes the companies that represent the top-30 percent of CGQ industry ratings, and the "Bad Governance" portfolio includes the companies that represent the bottom 30 percent of CGQ industry scores provided by Institutional Shareholder Services. 


\subsubsection{Abnormal Returns and the Structure of Corporate Governance}

To investigate the effects of corporate governance on the returns of equity REIT in more detail, we follow a two-stage approach. In the first stage, alpha is calculated for each company by employing the four-factor model proposed by Fama and French (1993) and Carhart (1997):

(2.1) $R_{i t}=\alpha_{i}+\beta_{0 i}\left(R_{m}-R_{f}\right)_{t}+\beta_{1 i}(S M B)_{t}+\beta_{2 i}(H M L)_{t}+\beta_{3 i}(M O M)_{t}+\varepsilon_{i t}$

where

$S M B=$ the monthly return on a small minus big factor portfolio in month $t$

$H M L=$ the monthly return on a high minus low book-to-price portfolio in month $t$

MOM = the monthly return on a past months' winners minus past months' losers portfolio in month $t$

Peterson and Hsieh (1997) find that the risk factors used in this model have been previously applied to explain returns on REIT stocks. Although there is an ongoing discussion whether the factors used in Carhart model are riskproxies, we avoid discussion of this issue and view it as a method of performance attribution. Thus, $\alpha_{i}$ can be interpreted as the return in excess of what could have been achieved by means of passive investment in the factors. The individual company alphas are calculated for the sub-periods from January 2003 through January 2007 and from February 2007 through May 2009, representing the boom period and the crisis period, respectively. We use the NAREIT Index ${ }^{7}$ as a proxy for the market return and the $S M B$, $H M L$ and MOM factors from the Kenneth French Data Library. ${ }^{8}$

\footnotetext{
${ }^{7}$ Our results are robust to using GPR Global 250 Index.

${ }^{8}$ Data obtained from

http://mba.tuck.dartmouth.edu/pages/faculty/ken.french/data_library.html.
} 
Table 2.3

\section{Cross-Sectional Regression of Pre-Crisis Abnormal Returns on Governance Scores}

\begin{tabular}{|c|c|c|c|c|c|}
\hline & (1) & (2) & (3) & (4) & (5) \\
\hline & \multicolumn{5}{|c|}{ Coefficient $\times 100$} \\
\hline CGQ Index & $\begin{array}{r}-0.010 \\
{[0.005]}\end{array}$ & & & & \\
\hline Takeover Index & & $\begin{array}{r}0.050 \\
{[0.084]}\end{array}$ & & & \\
\hline Audit Index & & & $\begin{array}{r}-0.214 \\
{[0.109]}\end{array}$ & & \\
\hline Board Index & & & & $\begin{array}{r}-0.006 \\
{[0.119]}\end{array}$ & \\
\hline Compensation Index & & & & & $\begin{array}{r}-0.241 \\
{[0.126]}\end{array}$ \\
\hline Debt Ratio & $\begin{array}{r}0.003 \\
{[0.007]}\end{array}$ & $\begin{array}{r}0.002 \\
{[0.007]}\end{array}$ & $\begin{array}{r}0.004 \\
{[0.007]}\end{array}$ & $\begin{array}{r}0.002 \\
{[0.007]}\end{array}$ & $\begin{array}{r}0.001 \\
{[0.007]}\end{array}$ \\
\hline FFO & $\begin{array}{r}-0.000 \\
{[0.000]}\end{array}$ & $\begin{array}{r}-0.000 \\
{[0.000]}\end{array}$ & $\begin{array}{r}-0.000 \\
{[0.000]}\end{array}$ & $\begin{array}{r}-0.000 \\
{[0.000]}\end{array}$ & $\begin{array}{r}-0.000 \\
{[0.000]}\end{array}$ \\
\hline Constant & $\begin{array}{r}0.774 \\
{[0.412]}\end{array}$ & $\begin{array}{r}0.001 \\
{[0.004]}\end{array}$ & $\begin{array}{c}0.878^{*} \\
{[0.430]}\end{array}$ & $\begin{array}{r}0.288 \\
{[0.519]}\end{array}$ & $\begin{array}{c}0.011^{*} \\
{[0.005]}\end{array}$ \\
\hline $\begin{array}{l}\mathrm{N} \\
\text { Adj. } \mathrm{R}^{2}\end{array}$ & $\begin{array}{r}133 \\
0.01\end{array}$ & $\begin{array}{r}133 \\
0.02\end{array}$ & $\begin{array}{r}133 \\
0.01\end{array}$ & $\begin{array}{r}133 \\
0.02\end{array}$ & $\begin{array}{r}133 \\
0.03\end{array}$ \\
\hline
\end{tabular}

Notes: Table 2.3 presents the results of the cross-sectional OLS regression of abnormal returns obtained from Equation (2.2). In the first stage, alpha is calculated for each company applying the four-factor from Jan 2003 to Jan 2007. In the second stage, those alphas are regressed on company corporate governance characteristics, leverage, and funds from operations over total assets. White's (1980) heteroskedasticity-robust standard errors are in brackets. * indicates significance at the 5 percent level. ${ }^{* *}$ indicates significance at the 1 percent level.

In the second stage, the generated alphas are regressed on corporate governance characteristics and company characteristics, using Equation 2.2, which is estimated using OLS, while correcting for heteroskedasticity following White (1980). ${ }^{9}$

\footnotetext{
${ }^{9}$ Karafiath (1994) evaluates the performance of OLS, weighted least squares, FGLS, and corrected least squares using Monte Carlo simulations, for cross-sectional regression that use abnormal returns. He finds that the ordinary least squares (OLS) estimator of abnormal returns is well-specified and performs as expected if the sample size is larger than 75 observations.
} 
(2.2) $\alpha_{i}=\delta_{0}+\delta_{1} G_{i}+\delta_{2}$ DEBTRATIO $_{i}+\delta_{3} \mathrm{FFO}_{i}+\vartheta_{i}$

where,

$G=$ a vector of governance characteristics of equity REIT $i$

DEBTRATIO = leverage ratio of equity REIT $i$

$F F O=$ funds from operations over total assets of equity REIT $i$

\section{Table 2.4}

Cross-Sectional Regression of Crisis Abnormal Returns on Governance Scores

\begin{tabular}{|c|c|c|c|c|c|}
\hline & (1) & (2) & (3) & (4) & (5) \\
\hline & \multicolumn{5}{|c|}{ Coeff. $\times 100$} \\
\hline CGQ Index & $\begin{array}{r}0.011 \\
{[0.006]}\end{array}$ & & & & \\
\hline Takeover Index & & $\begin{array}{r}0.188 \\
{[0.152]}\end{array}$ & & & \\
\hline Board Index & & & $\begin{array}{c}0.265^{*} \\
{[0.128]}\end{array}$ & & \\
\hline Audit Index & & & & $\begin{array}{c}0.270 * \\
{[0.127]}\end{array}$ & \\
\hline Compensation Index & & & & & $\begin{array}{r}0.081 \\
{[0.115]}\end{array}$ \\
\hline Debt Ratio & $\begin{array}{r}-0.011 \\
{[0.011]}\end{array}$ & $\begin{array}{r}-0.004 \\
{[0.011]}\end{array}$ & $\begin{array}{r}-0.010 \\
{[0.011]}\end{array}$ & $\begin{array}{r}-0.009 \\
{[0.011]}\end{array}$ & $\begin{array}{r}-0.007 \\
{[0.012]}\end{array}$ \\
\hline FFO & $\begin{array}{r}0.229 * * \\
{[0.072]}\end{array}$ & $\begin{array}{r}0.269 * * \\
{[0.071]}\end{array}$ & $\begin{array}{c}0.233 * * \\
{[0.070]}\end{array}$ & $\begin{array}{r}0.253 * * \\
{[0.069]}\end{array}$ & $\begin{array}{r}0.247 * * \\
{[0.068]}\end{array}$ \\
\hline Constant & $\begin{array}{r}-0.955 \\
{[0.558]}\end{array}$ & $\begin{array}{l}-1.4 * \\
{[0.7]}\end{array}$ & $\begin{array}{l}-1.260 * \\
{[0.568]}\end{array}$ & $\begin{array}{l}-1.537 * \\
{[0.663]}\end{array}$ & $\begin{array}{r}-0.870 \\
{[0.570]}\end{array}$ \\
\hline $\mathrm{N}$ & 112 & 112 & 112 & 112 & 112 \\
\hline Adj. $R^{2}$ & 0.13 & 0.13 & 0.14 & 0.13 & 0.11 \\
\hline $\begin{array}{l}\text { Notes: Table } 2.4 \text { pre } \\
\text { abnormal returns obt } \\
\text { calculated for each co } \\
\text { In the second stage, th } \\
\text { characteristics, levera } \\
\text { (1980) heteroskedast } \\
\text { significance at the } 5\end{array}$ & $\begin{array}{l}\text { ts the res } \\
\text { ed from } \\
\text { any applyir } \\
\text { e alphas ar } \\
\text { and fund } \\
\text {-robust st } \\
\text { nt level. }\end{array}$ & $\begin{array}{l}\text { s of the } \\
\text { uation }(2 \\
\text { the four- } \\
\text { regressed } \\
\text { from ope } \\
\text { idard err } \\
\text { ndicates s }\end{array}$ & $\begin{array}{l}\text { ross-sectiol } \\
\text { ). In the } \\
\text { ctor from F } \\
\text { on company } \\
\text { tions over } \\
\text { s are in } \\
\text { nificance at }\end{array}$ & $\begin{array}{l}\text { lal OLS re } \\
\text { first stag } \\
\text { eb } 2007 \text { to } \\
\text { corporate } \\
\text { total ass } \\
\text { brackets. } \\
\text { the } 1 \text { perc }\end{array}$ & $\begin{array}{l}\text { ression of } \\
\text { alpha is } \\
\text { May } 2009 . \\
\text { overnance } \\
\text { s. White's } \\
\text { indicates } \\
\text { nt level. }\end{array}$ \\
\hline
\end{tabular}


In Table 2.3, we provide the results of the cross-sectional estimation of Equation 2.2 for the pre-crisis period. ${ }^{10}$ We use the annual averages of the governance scores and financial firm determinants. The explanatory power of the models is low, and we do not find a statistically significant relation between governance and performance. This may be attributed to the very limited managerial discretion in cash flow spending of REIT management teams, due to the institutional framework surrounding U.S. REITs. (Bauer, Eichholtz, and Kok, 2010a)

Alternatively, these findings may indicate that (institutional) investors did not attribute any value to the particulars of REIT governance structures in the boom period that preceded the crisis. This irrational behavior would be fully consistent with the herd investments in securitized debt products, such as CDOs, where the opacity of the investments was so blissfully ignored. ${ }^{11}$

In Table 2.4, we estimate the effect of governance scores on abnormal returns during the crisis period, again applying Equation (2.2). Contrasting findings for the pre-crisis period, the results show that governance matters for stock performance of REITs during the crisis, even in the very strict legal setting in which REITs operate. These findings are in line with Mitton (2002). The coefficients for "Board" and "Audit" scores are significantly positive in the regressions, and the overall CGQ score is significantly positive at the 6 percent significance level. There is no significant effect of the quality of compensation structure on abnormal returns.

We can explain this in three ways. First, the "REIT effect" may be diminished during the crisis. REITs have to distribute 90 percent of income. However, this excludes depreciation. In times of crisis, the property portfolio of REITs will likely drop in value, so marking the value of the property holdings to market will imply a depreciation that is far more severe than the depreciation in normal periods. Since the depreciation expense is deducted from taxable income, this means that less cash has to be distributed to shareholders, leaving more free cash flows to the discretion of the managers, thereby increasing the need for good governance. In effect, the crisis makes REITs more like regular corporations and diminishes the "REIT-

\footnotetext{
${ }^{10}$ We also estimate the model including and controlling for delisted companies. The results are robust for existing REITs. The governance quality has no significant effect in these estimations, as well.

${ }^{11}$ Market equilibrium may be another explanation for the lack of a relation between governance and performance. However, given the flux in real estate markets preceding the crisis, this seems unlikely.
} 
effect" that results from the otherwise strong governance setting. This explanation is in line with a finding by Bauer, Eichholtz, and Kok (2010a), who show that the "REIT effect" is stronger for cash-constrained REITs and weaker for those REITs that have abundant free cash flows. This may also explain why especially the quality "Audit" is a significant and valuable aspect of corporate governance during the crisis.

A second explanation for the finding that firm-level corporate governance matters during the crisis, is that the expected returns to managers declines, since executive payment packages are likely to include bonuses that are based on absolute stock performance. That means executives may be more likely to become entrenched as compared to the pre-crisis situation (see Johnson, Moorman, and Sorescu, 2009).

Third, it may well be that (institutional) investors in real estate equities did not take corporate governance structures into account before the market collapsed. Corporate governance seemed to be ineffective in the listed real estate market and investors unrealistically revalued the stock price of the poorly governed companies. This implies that poorly governed companies were overvalued relative to well-governed property companies. The crisis lead investors to scrutinizing their securitized real estate holdings more intensively. As investors recognized the influence of corporate governance on REIT management and operational performance, a difference in share returns developed, related to the underlying corporate governance structure of property companies.

We observe that there is a time-specific effect in the relation between abnormal returns of real estate equity investments and governance structures: the effects of governance on stock performance change in direction and significance during the crisis. Overall, our results show that the relationship between abnormal returns and corporate governance is sensitive to time and the investment climate. These findings support the ideas of Gompers, Ishii, and Metrick (2003) and Core, Guay, and Rusticus (2006) that the relationship may be time specific and depends on the (irrational) exuberance of the investors. Additionally, and most important, the results for the crisis period show that corporate governance may become more important in a market downturn. The quality of governance matters during a crisis. 


\subsubsection{Abnormal Returns and Ownership Structure}

For a more thorough understanding of the importance of governance during the crisis, we also investigate how ownership concentration influences share performance after January 2007. If internal governance mechanisms are complemented by external governance mechanisms, such as block-holdings by institutional investors, the outperformance of well-governed companies strengthens, according to Cremers and Nair (2005). We address the ownership concentration separately for share ownership of executives and institutional ownership concentration. ${ }^{12}$ We exploit a similar econometric setup as in the previous analysis, but we now use ownership concentration data from the annual reports of the REITs, instead of the CGQ data as the main explanatory variable. We again control for annual financial characteristics.

The results are presented in Table 2.5. Model 1 analyzes the effect of executive ownership concentration on abnormal returns of real estate equities. However, as it is unlikely that executive stock ownership has a simple linear relation with stock performance, Model 2 includes the square of executive ownership. We find a convex and statistically significant relationship. At first, executive stock ownership affects abnormal returns negatively, which is in line with Ghosh and Sirmans (2003), who document that CEO ownership negatively affects REIT performance. This may be explained by executive stock ownership increasing executive power at the cost of the other shareholders (a "power effect"), which leads to increased entrenchment and could negatively affect operational performance.

On the other hand, executives who own company stocks also directly feel the financial pain of weak stock performance. It may that the power effect plays a dominant role at low degrees of executive share ownership, while if executives have a lot of skin in the game, underperformance would hurt them more than the possible benefits of expropriation. Indeed, executive stock ownership seems to have a negative performance effect up to a certain threshold, and a positive effect thereafter. It seems that beyond a certain level of insider ownership concentration, the interest of managers aligns with that of the existing shareholders. This is an important finding for (institutional) investors in property companies.

\footnotetext{
${ }^{12}$ The ownership concentration data are collected for 2006 in order to have the last point of observation before the crisis, following Mitton (2002).
} 
Table 2.5

\section{Cross-Sectional Regression of Crisis Abnormal Returns on Ownership Concentration}

\begin{tabular}{|c|c|c|c|c|}
\hline & $(1)$ & $(2)$ & (3) & (4) \\
\hline & \multicolumn{4}{|c|}{ Coefficient $\times 100$} \\
\hline \multirow[t]{2}{*}{ Executive Ownership } & $-2.345 *$ & -6.637* & & \\
\hline & [1.127] & {$[2.568]$} & & \\
\hline \multirow[t]{2}{*}{ [Executive Ownership] $]^{2}$} & & $6.971^{*}$ & & \\
\hline & & {$[0.297]$} & & \\
\hline \multirow[t]{2}{*}{ Largest Blockholder Ownership } & & & $0.140 * *$ & \\
\hline & & & {$[0.016]$} & \\
\hline \multirow[t]{2}{*}{ Total Blockholder Ownership } & & & & 0.001 \\
\hline & & & & {$[0.000]$} \\
\hline \multirow[t]{2}{*}{ Debt Ratio } & -0.008 & -0.003 & -0.007 & -0.004 \\
\hline & {$[0.011]$} & {$[0.011]$} & {$[0.010]$} & {$[0.010]$} \\
\hline \multirow[t]{2}{*}{ FFO } & $0.215^{* *}$ & $0.235^{* *}$ & $0.256 * *$ & $0.263 * *$ \\
\hline & {$[0.066]$} & [0.069] & {$[0.067]$} & {$[0.068]$} \\
\hline \multirow[t]{2}{*}{ Constant } & -0.014 & -0.142 & -0.675 & -0.850 \\
\hline & {$[0.662]$} & {$[0.680]$} & {$[0.565]$} & [0.573] \\
\hline $\mathrm{N}$ & 112 & 112 & 112 & 111 \\
\hline Adj. $R^{2}$ & 0.14 & 0.16 & 0.13 & 0.11 \\
\hline \multicolumn{5}{|c|}{$\begin{array}{l}\text { Notes: Table } 2.5 \text { presents the results of the cross-sectional OLS regression of abnormal } \\
\text { returns obtained from Equation ( } 2.2 \text {. In the first stage, alpha is calculated for each } \\
\text { company applying the four-factor from Feb } 2007 \text { to May } 2009 \text {. In the second stage, the } \\
\text { estimated alphas are regressed on corporate governance and financial characteristics of the } \\
\text { company. The ownership concentration data are the last available observations before the } \\
\text { crisis. White's (1980) heteroskedasticity-robust standard errors are in brackets. * indicates } \\
\text { significance at the } 5 \text { percent level. } * * \text { indicates significance at the } 1 \text { percent level. }\end{array}$} \\
\hline
\end{tabular}

In Models 3 and 4, we document that larger concentration of institutional stock ownership positively affects performance of property companies. The monitoring effect of institutional ownership over managers seems to be effective during the crisis. So, institutional investors in REITs seem to be able to influence the operations of these property companies. However, these results mainly hold if there is at least one large shareholder in the investor base. For total institutional ownership, the results are economically less powerful and only statistically significant at the 10 percent level. These results are consistent with the findings of Mitton (2002). 


\subsection{Concluding Remarks and Practical Implications}

Real estate has been at the forefront of the financial crisis, but thus far, investment research has mostly focused on the transparency and performance of securitized debt products, such as CMBS and CDOs. Listed property companies (REITs) offer an interesting insight about the role of transparency in the performance of real estate equity investments and the behavior of investors therein.

Previous evidence has shown that the agency conflict between managers and investors is reduced in REITs, as managerial freedom is curbed following legal requirements regarding obligatory payout and investment strategies. This may substitute the need for alternative corporate governance mechanisms and raise industry-wide governance standards. However, the limited effect of company-specific governance structures on the corporate performance of REITs has only been documented in rising or even booming market circumstances, and under bullish such conditions, governance may well receive less attention from investors.

Starting in 2007, the property market has shifted from boom to distress, with a very distinct break point. The legal restrictions regarding REIT cash flows might not be sufficient to decrease agency conflicts during the market downturn. In other words, under crisis circumstances, corporate governance may again become of importance to investors. Our results seem to suggest that the structure of firm-level corporate governance mechanisms became more critical during the crisis.

Using a sample of U.S. equity REITs during the 2003 - 2009 period, we find that governance practices did not significantly affect abnormal stock returns during the market boom. But during the crisis, the relation between governance and performance in REITs rapidly became positive and significant. Our results show that the results are mostly driven by the quality of corporate governance that is related to board composition and audit quality.

Additionally, we document a positive, convex relationship between abnormal returns and executive ownership concentration during the crisis period. Insider ownership affects stock performance negatively below a threshold and positively above that threshold. Our results also show that abnormal 
returns are positively affected by the ownership concentration among the largest institutional shareholders during the crisis.

The previously documented "REIT effect", resulting from the strong industry-wide governance framework, seems to disappear during the crisis. We explain this by the fact that the crisis increases depreciation in REITs, thus reducing the required cash distribution, and leaving more cash at the discretion of management.

The second explanation is that the crisis decreases managers' performancebased compensation, thus increasing the incentives for entrenchment. As a result, the effectiveness of the governance setting surrounding REITs is weakened, and REITs more closely resemble regular corporations in the importance of firm-level governance for share performance.

Third, these findings may indicate that (institutional) investors did not attribute any value to the governance structure of REITs in the boom period that preceded the crisis. This irrational behavior would be fully consistent with the investments in securitized debt products, such as CDOs, where opacity of the investments was ignored as well.

An important implication of our findings concerns the possibility for mandatory payout rules and other institutional limitations on managerial discretion. Our pre-crisis results support the earlier findings of Bauer, Eichholtz, and Kok (2010a), suggesting that the institutional design of REITs alleviates the need for company-specific governance measures. This may be viewed as an argument to introduce such measures in a wider set of industries. However, we have some serious doubts as to whether the institutional lessons from the REIT market can be simply applied to improve the institutional infrastructure for investments in other industries.

First, the real estate industry is all heavily income-focused, but many other industries are not. In the high-tech sector, for example, dividend payments are rare. Shareholders accept low or no dividend payments, since they may view the internal reinvestment of retained earnings as value enhancing in the long run. Introducing mandatory payout to these industries would probably do more harm than good.

Second, our empirical results for the crisis suggest that the manner in which the payout rule is defined is not crisis-proof. It may be better to set the payout requirements relative to the free cash flow rather than relative to the 
income, leaving less discretionary cash for managers. This would diminish the importance of depreciation and decrease the possibility of agency problems and earnings managements. Last, the payout rule was never designed as a governance mechanism, but as a guarantee that the tax authorities would receive their taxes (If not at the corporate level, then at the shareholder level.) This implies that mandatory payout may just be accepted as a quid pro quo for a zero corporate tax rate.

Our results do have important implications for institutional investors that invest in real estate equity via intermediate property companies. In "regular" times, investors can rely on the beneficial governance setting derived from the institutional framework surrounding REITs. Attention to firm-level corporate governance may be of less importance under these circumstances, which is one of the main benefits of investing in REITs as compared to investing directly in real property or in private property funds, where governance is a far more problematic issue, according to Brounen, Veld, and Raitio (2007).

This implies that the costs of monitoring REIT portfolios are substantially lower as compared to the cost of managing portfolios of directly held real estate. This is illustrated by the fact that the human capital required for the portfolio management of REIT assets is substantially smaller as compared to the management of a portfolio of real property, even if the actual property management is outsourced.

However, our results also suggest that the quality of firm-level governance matters, especially during times of crisis. These periods are arguably the times that investors are most concerned about, especially from a riskmanagement perspective. This implies that institutional investors should always focus on the quality of the firm-level corporate governance of the REITs they invest in, regardless of the economic circumstances. This ensures the best all-weather approach towards real estate equity investments.

We consider this research as just a step towards a better insight into the corporate governance of REITs. For future research on this topic, some interesting and important issues remain. First, there is the question whether REITs - or property companies in general - should be managed internally or externally. In the last ten years or so, the capital markets have shown diverging trends regarding this issue. For example, out of the 23 property 
companies listed on the Alternative Investment Market in London during 2005 and 2006, only three were internally managed (see Citigroup, 2006).

On the other hand, externally managed REITs have almost disappeared in the U.S. Before 1986, U.S. REITs were all externally managed, but since the law changed in that year, REITs have been allowed to make their investment decisions internally and to manage property in-house.

The academic evidence suggests that this shift has been beneficial for the creation of shareholder value, due to reduced agency problems. Howe and Shilling (1990) document that externally managed U.S. REITs experience negative abnormal returns over the period from 1973 through 1987. Using data from 1987 through 1992, Cannon and Vogt (1995) show that REITs with internal management significantly outperform externally managed REITs.

Capozza and Seguin (2000) find that REITs managed by external advisors underperform internally managed REITs by an astonishing 7 percent per year. Importantly, property-level cash flow yields are similar between the two managerial forms, but corporate-level expenses and especially interest expenses are responsible for lower levels of cash available to shareholders in externally advised REITs. Obviously, compensating managers based on either assets under management or on property level cash flows creates incentives for managers to increase the asset base by issuing debt, even if the interest costs are not favorable. Ambrose and Linneman (2001) also document that internally-advised REITs dominate externally-advised REITs, mainly because of reduced conflicts of interest.

In sum, the U.S. REIT industry provides a natural experiment regarding the merits of external versus internal management for property companies. The results of this experiment show that internal management is the preferred choice, creating management incentives for optimizing share performance. However, this issue has not been investigated as thoroughly for property companies and REITs outside of the U.S., and this is clearly a promising avenue for future research.

Another aspect of governance is the effect of ownership restrictions. In many countries with REIT structures in place, property companies opting for these structures are obliged to adhere to certain requirements regarding their ownership. In the U.S., for example, REITs need to have at least 100 
shareholders, with the five largest shareholders owning a maximum of 50 percent of the shares. These rules are meant to ensure that REITs are easily accessible for retail investors, but they have some negative implications for corporate governance, since they lead to more dispersed ownership.

The rules make it difficult for blockholders to acquire ownership stakes, and for shareholders in general to form alliances and pose a takeover threat. Since hostile takeovers are very rare in the listed property sector, Allen and Sirmans (1987), Campbell, Gosh, and Sirmans (2005) have argued that this is evidence for a non-functioning market for corporate control. However, hostile takeovers are also absent in non-REIT property share markets outside of the U.S., and poorly performing property companies face a higher takeover likelihood as compared to well-performing property companies, as Eichholtz and Kok (2008) document.

Nevertheless, the requirements regarding ownership structure are likely to hinder the monitoring role of large shareholders and their possibility to diversify investments substantially into real estate. Indeed, prior to the 1993 change in U.S. regulations regarding the holdings of REIT shares by institutional investors, these investors were underrepresented in REIT stocks (see Ling and Ryngaert, 1997). Since this hindered blockholder monitoring, it weakened the governance of REITs. U.S. regulators realized this and changed the regulations in such a way that institutional investors were no longer treated as a single investor, but rather as an investor representing numerous individual investors.

Following the change in REIT regulation, U.S. REITs have attracted more institutional investors (see Chan, Leung, and Wang, 1998). This has also been beneficial to retail investors. Wang et al. (1995) show that the participation of institutional investors increases the control and monitoring ability of shareholders, thereby increasing the value of REIT stocks. In 2007, the Netherlands also revised its REIT legislation, and, following the U.S. example, has eliminated most of the shareholder requirements that previously applied.

In sum, the academic literature strongly suggests that restrictions regarding the ownership structure of a REIT lead to weaker governance and inferior performance, and are therefore not recommended, even if these rules seem to protect smaller investors. This is underlined by the fact that the two countries with the longest experience with tax-transparency for property 
companies - the U.S. and the Netherlands -both abolished the previously existing restrictions regarding ownership. Again, this issue has not been addressed as extensively for countries outside of the U.S. and ownership restrictions remain in place for many of the countries that have more recently introduced REIT structures. More research is needed on this issue.

Besides the aspects of governance discussed in this chapter, the legal infrastructure surrounding REITs offers another interesting aspect of governance. The dominant organizational structure in the U.S. REIT is the umbrella partnership REIT, or UPREIT. This structure was created to postpone or avoid capital gains tax for the owners of real estate that sell their holdings to a REIT, but it also has important consequences for corporate governance.

The disposition of properties to a REIT leads to "umbrella partnership" units, which can be converted into the ordinary shares of the REIT. Subsequently, these shares can be sold on the market. The conversion triggers the payment of capital gains tax, so unit holders are less likely to "vote with their feet" on unwanted management actions, which weakens their influence on management.

The UPREIT structure may thus affect the functioning of corporate governance mechanisms. This raises the question how UPREITs perform relative to other REITs: if the tax benefits of the structure outweigh the detrimental effects of weaker corporate governance, the result will be better shareholder performance. Hartzell, Sun and Titman (2006) do not find a significant effect of the UPREIT status on the degree to which REITs' investments affect their valuations.

More recently, Hartzell, Kallberg and Liu (2008) investigated this effect by looking at REIT valuations surrounding IPOs, and they document a positive relation between UPREIT status and firm valuation. These results suggest that the potential detrimental effects resulting from weaker governance are not very strong, but this is an aspect that has not received a lot of attention in the literature yet. Given the importance of the UPREIT structure for the REIT industry, more research is clearly needed.

Concluding, the legal structure surrounding REITs offers a highly interesting natural experiment for the study of corporate governance. This chapter offers insight into the effects of corporate governance structure on REIT 
performance, but some open questions remain, providing a promising venue for further research. 


\section{Chapter 3 \\ CEO Overconfidence, Corporate Investment Activity, and Performance ${ }^{13}$}

\subsection{Introduction}

Overconfidence is one of the main behavioral biases discussed in the behavioral finance literature, and its existence has been well documented by anecdotal and academic evidence alike. The main research question that arises in the literature is whether overconfidence affects investor decisions and thereby performance. Overconfident people think that their decisions are better and will bring superior outcomes, either in terms of returns or in risk. Benos (1998) states that overconfident investors believe that their convictions are better than they are in reality. Hirshleifer and Luo (2001) claim that overconfident investors will underestimate the risk of their investments. As a result, they trade more frequently.

Most of the evidence supports the proposition that overconfidence negatively influences the outcomes of people's decisions. This evidence mostly concerns individual investors, and mostly deals with investor behavior regarding stock portfolios. Generally, these studies investigate whether there is interdependence between overconfidence and trading activity, where trading activity can be interpreted as a proxy for decisions - decisions to buy, sell, or hold stocks. A common result of these studies is that the decisions of investors are indeed affected by overconfidence: overconfident investors are found to trade more than their non-overconfident counterparts (see for example Benos (1998), Odean (1998b), and Barber and Odean (2000)). This overtrading is generally found to be associated with weak investment performance, implying that superior information is not the cause of the trading intensity.

The few exceptions that deal with the effect of overconfidence within a corporate setting include most notably the empirical work by Malmendier and Tate (2005a) and Malmendier, Tate and Yan (2011). They use a number of proxies for overconfidence, and show that the interaction term of available cash and overconfidence is positively and significantly related to the intensity of capital expenditure within corporations. This result suggests

${ }^{13}$ This chapter is based on Eichholtz, Piet and Erkan Yönder. 2012. "CEO Overconfidence, Corporate Investment Activity, and Performance: Evidence from REITs," Working Paper. 
that the investment decisions of corporations are affected by overconfidence of the CEO.

We investigate the corporate investment activity in US Real Estate Investment Trusts (REITs). The advantage of looking at REITs is that their individual investments can be exactly identified. So REITs offer the researcher a direct look at the investment activity that goes on within a company as a going concern. For most other corporations, this is not possible.

Furthermore, it is usually not possible to determine the value of individual investment projects within a corporation. Here also, REITs offer a special opportunity for the researcher, because information regarding the value of all the assets held by the REITs is available. REITs are legally required to have 75 percent of their assets invested in real estate assets, and in practice, they invest almost all their capital in it. The REITs in our sample had on average 98.6 percent of their assets in real estate over the sample period. Therefore, the projects that REITs undertake are predominantly the acquisition, operation, and sale of real estate, and they report the acquisition and sales values.

Because of these reporting requirements, the beginning and the end of each investment project can be clearly observed. So the econometrician can observe the time of the decisions to start (acquisition), to hold (operation), or to end (sale) projects. Consequently, it is possible to create measures of corporate investment activity. These are based on the dollar value of purchases and sales of properties and the number of properties purchased and sold. We separately investigate corporate purchasing and sales activity, following Glaser and Weber (2007), who find that buy and sell decisions are driven by different factors.

We estimate the relation between corporate investment activity and CEO overconfidence measures, using appropriate control variables. CEO overconfidence is approximated by the CEO's trading in own-company stock and in the exercise of stock options. This chapter regards a CEO as overconfident if he is a net buyer of his own company's stocks in more years than he is otherwise throughout the sample period.

We also define a CEO as overconfident if he is a long holder of a stock option that is exercisable, i.e. if he postpones exercising an in-the-money 
stock option until the expiry year and if this behavior occurs at least twice. The logic behind this is that if a CEO exercises the in-the-money stock option, he will increase his wealth but he postpones exercising the option because he believes that he will do better, as a result, the price of his company stock will go up more. In order to separate overconfidence from private information, we define a CEO as overconfident if we observe such behavior at least twice.

We show that REITs with overconfident CEOs - and with discretionary cash - invest more than their counterparts who are not led by an overconfident CEO. We also look at acquisition and disposition activity separately. Overconfident CEOs significantly increase the acquisition activity of their REIT when the cash to assets ratio increases. Also, we find evidence that these REITs sell less than their counterparts if they have enough available cash. Our findings are consistent for both overconfidence measures we employ.

In principle, it is possible that a CEO is a net buyer of own-company stocks or a long holder of his corporate stock options not because he is overconfident, but because he has valuable private information. In that case, the REIT's observed investment behavior could be warranted by this private information, rather than by CEO overconfidence.

We address this concern in a number of ways. First, when CEOs have valuable private information, it is likely to be temporary, whereas overconfidence is apt to be habitual behavior. So to address this issue, we check whether the CEO is a net buyer throughout the whole sample period instead of looking at this annually. Second, we investigate the association between the CEO's stock buying and option exercise behavior and the operating performance of the REIT. We find that REITs whose CEOs are net buyers in a given year perform worse in the next year; making is unlikely that valuable private information is the driver of the corporate investment activity. Using property type $\mathrm{Q}$ as a proxy for investment opportunities (following Hartzell, Sun, and Titman, 2006) and return on assets, we find significant evidence that when a CEO is overconfident, an increase in cash to assets leads to a decline in financial performance. 


\subsection{Literature Review}

Overconfident people tend to overestimate the outcomes of their decisions and underestimate the risks associated with those decisions in the literature. Benos (1998) reasons that overconfidence can result from investors believing that their convictions are better than they are in reality, which, in its most extreme representation, leads investors to believe that they are always precisely correct. Hirshleifer and Luo (2001) define overconfidence as "overestimation of the precision of private information signals", which means that overconfident investors will simply underestimate the risk of an investment.

The question whether overconfidence stays or changes over time has also been addressed. Menkhoff and Nikiforow (2009) show that the knowledge of behavioral biases changes the way the managers perceive the markets, but not the way they see themselves. The evidence consequently indicates that learning cannot remove overconfidence, as this is a characteristic that is inherent within the person, not the market. Hirshleifer and Luo (2001) model a market environment in which they can observe the evolution of the overconfident and rational investor population, but where the individual overconfidence level does not evolve over time.

Gervais and Odean (2001) develop a model in which they can observe the evolution of overconfidence within investors as opposed to Hirshleifer and Luo (2001) who examine the evolution of the overconfident and rational investor population. They show in a dynamic multi-period market model that overconfidence resulting from self-attribution bias is a personality trait that can be learned and that can vary over time, depending on recent experience.

De Long et al. (1991) create a model that allows them to show whether rational traders or noise traders will dominate the market, or if one of the groups will even eventually die out. Noise traders are defined as investors who wrongly interpret information and underestimate risk, and therefore tend to take more risk than they usually would.

Whereas in the model of De Long et al. (1991) it is assumed that overconfident investors simply tilt their portfolios extremely to the market portfolio because they underestimate its risk, Hirshleifer and Luo (2001) develop a model where investors trade more aggressively on their 
information since they underestimate the risk they take and overestimate the expected value they get by trading.

De Long et al. (1991) argue it is because of higher risk taking that some overconfident traders are successful and become very wealthy. On the other hand, Gervais and Odean (2001), argue it is exactly the other way round. According to their reasoning it is not overconfidence that makes traders wealthy. Traders are made overconfident by the process by which they become wealthy and therefore there will always be overconfident traders in equilibrium.

It has been suggested so far that overconfidence affects individual investors' trading patterns as well as their returns. Generally this literature shows that overconfident individual investors tend to trade more (Benos, 1998; Odean, 1999, Barber and Odean, 2001, 2002; Chuang and Lee, 2006; and Deaves, Lüders, and Luo, 2009), thereby harming their returns (Odean, 1999; Barber and Odean, 2000a, 2001, 2002; and Biais et al., 2005).

Benos (1998) develops a strategic trading model based on a call auction market with some overconfident investors where he shows that the profits of overconfident traders should actually be higher than those of rational traders. The model shows that overconfident investors increase trading, which is in line with noise theory proposed by Black (1986) in which trading is induced by noise, i.e., a misevaluation of information.

Also studying market models that are built on the assumption that investors are rational with the exception of how they value the available information, Odean (1998b) finds that the most robust effect that is caused by overconfidence is that trading volume increases.

In a later empirical study based on the findings of these models, Odean (1999) explicitly tests the hypothesis that individual investors will trade too much with respect to what could be expected from a rational point of view due to overconfidence. He shows that on average the returns of investors are reduced due to trading, even after controlling for trades that potentially are motivated by rational reasons such as liquidity needs, portfolio rebalancing or tax-motivated sales.

The conclusion is that it is overconfidence that induces investors' trading. The results show that even in the absence of trading costs investors harm their performance with their trading due to their stock selection, which is an 
even stronger result than the one predicted by the overconfidence hypothesis.

The relationship between overconfidence and individual performance has also been investigated. Barber and Odean (2000) show in their analysis of the portfolio performance of individual investors that those trading most have the lowest returns net of trading costs, with a negligible difference gross of trading costs, confirming the results of Odean (1999). In a following study Barber and Odean (2001) link high trading to overconfidence by testing the hypotheses that men trade more than women, and that because they trade more they have lower returns.

Gervais and Odean (2001) find that aggressive trading of overconfident investors increases trading volume and leads to lower expected profits due to suboptimal behavior. This means that a successful investor's expected profits may in fact be lower than the expected profits of an investor that is less successful, and they conclude that although successful investors are inclined to be good, they are less good than they themselves believe they are.

Barber and Odean (2002) find additional evidence for the hypothesis that overconfidence leads to increased trading. They show that after switching their brokerage accounts from telephone-based trading to online trading, investors perform far worse than before, despite lower trading costs. This fact is attributed to the higher trading frequency, which is induced by overconfidence. It negatively affects investorperformance, a phenomenon that was already observed by in an earlier study by the same authors (Barber and Odean, 2000).

Chuang and Lee (2006) suggest that overconfidence induces more trading than could be rationally argued for. They also find that overconfident investors suffer from self-attribution bias and react more to private information than to public information. Because traders believe by mistake that their information is superior and that they have better abilities than other traders, they will trade. Furthermore, overconfident investors are also found to trade more in riskier stocks.

Most of the studies in the overconfidence literature investigate individual investors. There are very few papers evaluating overconfidence for corporations. Malmendier and Tate (2005a) investigate managerial 
overconfidence for corporations and prove that corporate investment by overconfident CEOs is more sensitive to cash flow than corporate investment of non-overconfident CEOs. When there is available cash flow, overconfident CEOs invest more. In their paper, they do not evaluate individual investment decisions but instead use an overall investment measure.

In a follow-up paper, Malmendier and Tate (2008) investigate whether CEO overconfidence affects merger decisions. They find that CEOs pay more for target companies and that mergers of companies led by overconfident CEOs are value-destroying. Internal financing strengthens these relationships.

Billett and Qian (2008) show that it is past successes that make CEOs overconfident. They find evidence that following acquisitions that were successful CEOs are more likely to engage in further acquisitions than after acquisitions that were not. However, these follow-up acquisitions are not profitable anymore. These findings are linked to Roll's (1986) hubris hypothesis, which predicts that, due to a positive valuation error, acquiring firms pay too high a price for acquiring their targets because managers overestimate their abilities to create synergies from the combination.

\subsection{Data and Method}

\subsubsection{Measuring CEO Investment Decisions}

The task of measuring CEO investment decisions is cumbersome: even if they are observable, they are likely to be very heterogeneous, and therefore difficult to compare. Moreover, their exact value is not known, and the same holds for their timing. Studying REITs provides a unique opportunity in that regard: they allow the researcher to observe corporate decisions made by management, and these decisions are not hampered by the three measurement problems described above.

First of all, to make or model comparable with the literature, we measure investments by using real estate investment growth. Additional to the existing literature, we also separately look at purchases and sales of properties. The reason for evaluating sales and purchases separately is argued by Glaser and Weber (2007). They find that the decision to buy or sell is driven by different factors. This is because the choice of shares to be sold is limited to the shares that are in the portfolio (assuming no short 
sales), whereas there is a virtually unlimited choice of shares to buy. The same argument should apply to real estate, and probably even more strongly, as short selling in real property is not possible.

Furthermore, when selling shares investors tend to consider both their past and future performance whereas when buying shares they consider future performance only. This phenomenon is commonly called the disposition effect and is based on Kahneman and Tversky's (1979) prospect theory, which posits that investors will sell their winning investments while holding on to their losing investments in order to avoid regret. The disposition effect was first empirically investigated by Shefrin and Statman (1985) and is well documented by several other studies (Barber et al., 2007; Barber and Odean, 1999; Odean, 1998a).

Crane and Hartzell (2008) study the disposition effect on REIT investment activity. They prove that, consistent with the disposition effect, REIT managers tend to sell their winning properties and hold on to their losing properties as measured by the price change since the acquisition of the properties.

Taking all this evidence of an asymmetry between buying and selling decisions together, we expect that the effect of CEO overconfidence will be different for corporate purchases from that for sales. We measure corporate investment activity separately for acquisitions and dispositions, following the methodology of Brounen, Eichholtz, and Ling (2007).

We use the number of properties purchased and sold in each year to proxy Purchases and Sales, respectively, and the total number of properties in the portfolio of REIT $i$ at time $t$ to proxy for RE. The equations for Acquisitions and Dispositions are as follows:

(3.1) Acquisitions $_{i t}=\frac{\text { Purchases }_{i t}}{\left(R E_{i(t-1)}+R E_{i t}\right) / 2}$ 
(3.2) Dispositions $_{i t}=\frac{\text { Sales }_{i t}}{\left(R E_{i(t-1)}+R E_{i t}\right) / 2}$

\subsubsection{Measuring CEO Overconfidence}

We measure CEO overconfidence as in Malmendier and Tate (2005a, b, 2008). The CEOs who fail to minimize the exposure of their personal wealth to company-specific risk are defined as being overconfident. This is because failure to do so indicates an overestimation of their companies' future returns. As a large fraction of a CEO's wealth is dependent on the company he works for (regular income, health insurance, pension plan, etc.), his exposure to company-specific risk is large to begin with, so enlarging it suggests that the CEO is very confident of the company's fortunes.

Following Malmendier and Tate (2005a), the first measure of CEO overconfidence is the Net Buyer measure. It exploits the fact that some CEOs tend to buy additional own-company stock although their personal wealth is already highly exposed to company risk. The phenomenon that CEOs buy more own-company stock after they have been classified as overconfident has been documented by Billett and Qian (2008). We identify whether a CEO buys more of his own-company stocks than he sells annually. If a CEO is a net buyer in more years then he is otherwise, we define that CEO as overconfident. ${ }^{14}$

If a CEO is overconfident as defined with the net buyer measure, he exposes himself deliberately to company risk although he could diversify and invest the money in the market portfolio, which has superior expected risk-return characteristics. Due to overconfidence a CEO may overestimate the prospective returns of his own company's investment projects, and believe that he is better able to manage his company than the average CEO and expects that during his leadership the stock price of his company will perform better than those of other companies. Because of these beliefs,

\footnotetext{
${ }^{14}$ To obtain higher persistence, we also define CEOs as overconfident if a CEO is a net buyer in at least two more years then he is otherwise. In unreported regressions, the results are also robust with this stricter net buyer definition.
} 
overconfident CEOs will be net buyers more often in order to profit from the future gains they expect.

Malmendier and Tate (2005a) define a CEO as overconfident according to this measure if he was a net buyer of company stock during his first five years in the sample. As the number of REITs are limited and some REITs also replace their CEOs, a CEO will be categorized as overconfident if he is a net buyer during the sample period or during his tenure as a CEO of a REIT, whichever is longer.

We take the CEOs with at least a 2-year appearance in the sample period from 2003 till 2010 into consideration. The sample with this measure consists of 146 REITs. As a robustness check, we also limit our sample of CEOs with at least a 5-year appearance during the sample period. We do this to check to see whether there is a mismeasurement of overconfidence due to the possibility that 2 years of observed behavior could possibly not be sufficient to classify managers as overconfident or non-overconfident. Going from 2 to 5 years reduces the number of REITs with overconfident CEOs to 93. If CEO overconfidence is detected, we define him as being overconfident for all years of his tenure. We establish a net buyer dummy variable with the value 1 meaning "overconfident".

The second measure of overconfidence is the Long Holder dummy created following Malmendier and Tate (2005a). Suppose a manager has an exercisable, in-the-money stock option. A manager who does not exercise the in-the-money option and postpones exercising it until the expiry year is likely to be confident that the company will do well in the future under his management and the stock performance will be superior than that of the alternative, i.e. to exercise and invest the proceeds in the market portfolio.

Firstly, we identify CEOs of REITs who exercised their stock options at least once before or in the expiry year. We restrict our sample to these CEOs and we end up with a sample of 83 REITs. Among CEOs of those 83 REITs, we then identify CEOs who exercise their stock options in the expiry year at least twice, so to say who are long holders at least twice. We establish a long holder dummy variable with the value one meaning "overconfident". 


\subsubsection{Data and Model}

The whole dataset consists of US REITs listed by SNL Financial Real Estate in the period between 2003 and 2010. It includes REITs that started or ceased operations during this period in order to avoid survivorship bias. Data on real estate investment growth and the number of properties sold and purchased are obtained from the SNL Financial Real Estate database on an annual basis. Data on stock options and the purchases and sales of own-company stock for each CEO are directly collected from Thomson Reuters Insider Filings Data. Financial data are from SNL Financial Real Estate and Worldscope. After matching financial data with stock option and stock trading data, our sample covers 146 REITs in total.

Table 3.1 presents descriptive statistics. In Panel $A$, we show means of overconfidence dummies. 34-35 percent of CEO-years of a sample of REITs with at least 2 CEO-years and at least 5 CEO-years are overconfident. 21 percent of CEO-years are defined as overconfident when we measure overconfidence by the long holder dummy.

The average annual real estate investment growth is 14 percent. When we look at acquisitions and dispositions separately, the annual number of properties purchased normalized by the total number of properties is 14 percent and the annual number of properties sold normalized by the total number of properties is 6 percent.

The mean of the cash to assets ratio is 2 percent while the debt to assets ratio is 54 percent on average. The average firm age defined by years since initial public offerings is 16 years. Firm specific $Q$ is the Tobin's q ratio, defined as the market value of common equity plus total assets minus the book value of common equity, divided by firm's total assets. Mean of firm specific Q by property type by year is 1.36 , which is also the same as the mean of firm specific $Q$, by definition. The mean of return of assets as an alternative financial performance indicator to firm specific $Q$ is 2.65 . 
Table 3.1

\section{Descriptive Statistics}

\begin{tabular}{|c|c|c|c|c|c|}
\hline VARIABLES & Obs. & Mean & Std. Dev. & Min & Max \\
\hline \multicolumn{6}{|c|}{ Panel A - Overconfidence } \\
\hline Net Buyer (at least 2 CEO-Years) & 770 & 0.34 & 0.47 & 0.00 & 1.00 \\
\hline Net Buyer (at least 5 CEO-Years) & 606 & 0.35 & 0.48 & 0.00 & 1.00 \\
\hline Long Holder & 390 & 0.21 & 0.41 & 0.00 & 1.00 \\
\hline \multicolumn{6}{|c|}{ Panel B - Corporate Investment Activity } \\
\hline Real Estate Investment Growth & 770 & 0.14 & 0.31 & -0.51 & 3.07 \\
\hline Acquisitions & 759 & 0.12 & 0.18 & 0.00 & 1.69 \\
\hline Dispositions & 759 & 0.06 & 0.10 & 0.00 & 1.40 \\
\hline \multicolumn{6}{|c|}{ Panel C - Control Variables } \\
\hline Cash to Total Assets & 770 & 0.02 & 0.04 & 0.00 & 0.37 \\
\hline Total Assets (in billion US\$) & 770 & 3.34 & 4.09 & 0.28 & 25.90 \\
\hline Debt Ratio & 770 & 0.54 & 0.17 & 0.00 & 1.29 \\
\hline Firm Age & 770 & 15.84 & 11.77 & 0.00 & 57.00 \\
\hline Property Type $Q$ & 770 & 1.36 & 0.18 & 0.87 & 1.68 \\
\hline
\end{tabular}

Panel D - Financial Performance

\begin{tabular}{lrrrrr} 
Firm $Q$ & 770 & 1.37 & 0.34 & 0.60 & 2.92 \\
$R O A$ & 770 & 2.65 & 4.25 & -19.21 & 35.28 \\
\hline
\end{tabular}

Notes: Table 3.1 presents descriptives statistics. Overconfidence is either defined as net buyer dummy or long holder dummy. Net buyer dummy is applied over a sample of REITs with either at least 2 CEO-years or at least 5 CEO-years. Real estate investment growth, acquisitions and dispositions defined by using number of properties are used as a proxy for corporate investment activity. We use a set of controls including cash to total assets ratio, debt to total assets ratio, total assets, firm age and mean of firm specific $Q$ by property type by year. Firm specific $Q$ and return on assets are used as financial performance indicators. The data range from 2004 to 2010 .

In order to investigate the effect of CEO overconfidence on corporate investment activity, we estimate the following equations, applying a random effects model:

$$
\text { (3.3) Investment } \text { It }=\alpha_{0}+\alpha_{1} O C_{i}+\alpha_{2} O C_{i}^{*} \operatorname{Cash}_{i t}+\alpha_{3} \text { Cash }_{i t}+\alpha_{4} X_{i t}+\varepsilon_{i t}
$$


We use Real Estate Investment Growth as the investment variable defined by SNL Financial as a proxy of corporate investment activity. This investment growth ratio is calculated using property investments in dollar values. We also use acquisition and disposition activity as the dependent variable, applying equation 3 with Acquisitions and Dispositions, respectively.

$O C$ is a dummy variable that is the net buyer dummy or the long holder dummy. Cash is the cash to total assets ratio at the end of the previous year. We interact the overconfidence dummy with Cash because the effect of overconfidence on investment is likely to be sensitive to cash availability.

$X$ is a vector of controls including debt ratio at the end of the previous year, the logarithm of total assets as a proxy for firm size, firm age, property type dummies and year dummies. We also include Property Type $Q$ which is the mean of firm specific $Q$ by property type by year at the end of previous year as a proxy for investment opportunities following Hartzell, Sun, and Titman (2006).

\subsection{CEO Overconfidence and Corporate Investment Activity}

\subsubsection{Investment Activity}

We expect that corporate investment activity increases with CEO overconfidence. Table 3.2 presents the estimation results for Equation (3.3). The heteroscedasticity robust and firm-clustered standard errors are in brackets. Column 1 of Table 3.2 shows the regression with financial controls. If there is an increase in cash to assets, investments significantly increase as well. Investments decline with an increase in debt to total assets ratio. However, in some specifications, we find an insignificant relationship. We also find that younger firms significantly invest more. Additionally, investment is positively related to Property Type $Q$, which is a proxy for investment opportunities. 
Table 3.2

The Effect of CEO Overconfidence on Corporate Investment Activity

\begin{tabular}{|c|c|c|c|}
\hline \multicolumn{4}{|c|}{ Panel A - Net Buyer (At Least 1 CEO-Year) } \\
\hline VARIABLES & $\begin{array}{c}(1) \\
\text { Investment }\end{array}$ & $\begin{array}{c}(2) \\
\text { Investment }\end{array}$ & $\begin{array}{c}(3) \\
\text { Investment }\end{array}$ \\
\hline Net Buyer & & $\begin{array}{c}0.057 * \\
{[0.034]}\end{array}$ & $\begin{array}{r}-0.027 \\
{[0.034]}\end{array}$ \\
\hline Net Buyer*Cash & & & $3.046 * * *$ \\
\hline & & & [0.870] \\
\hline Cash & $\begin{array}{r}1.928^{* * *} \\
{[0.7171}\end{array}$ & $\begin{array}{r}1.807 * * * \\
{[0.650]}\end{array}$ & $\begin{array}{r}0.474 \\
0.5511\end{array}$ \\
\hline $\ln ($ Size $)$ & $\begin{array}{r}0.002 \\
{[0.012]}\end{array}$ & $\begin{array}{r}0.016 \\
{[0.013]}\end{array}$ & $\begin{array}{r}0.016 \\
{[0.012]}\end{array}$ \\
\hline Debt Ratio & $\begin{array}{r}-0.084 \\
{[0.097]}\end{array}$ & $\begin{array}{r}-0.018 \\
{[0.114]}\end{array}$ & $\begin{array}{r}-0.018 \\
{[0.108]}\end{array}$ \\
\hline Firm Age & $\begin{array}{r}-0.004 * * * \\
{[0.001]}\end{array}$ & $\begin{array}{r}-0.003 * * * \\
{[0.001]}\end{array}$ & $\begin{array}{r}-0.003 * * * \\
{[0.001]}\end{array}$ \\
\hline Property Type $Q$ & $\begin{array}{r}0.260 * * * \\
{[0.071]}\end{array}$ & $\begin{array}{r}0.393^{*} \\
{[0.224]}\end{array}$ & $\begin{array}{r}0.371 \\
{[0.228]}\end{array}$ \\
\hline Constant & Yes & Yes & Yes \\
\hline Property Type & No & Yes & Yes \\
\hline Year Dummies & No & Yes & Yes \\
\hline Observations & 770 & 770 & 770 \\
\hline R-squared & 0.12 & 0.20 & 0.23 \\
\hline Panel B - N & t Buyer (At & Least 5 CEO & -Years) \\
\hline VARIABLES & $\begin{array}{c}(1) \\
\text { Investment }\end{array}$ & $\begin{array}{c}(2) \\
\text { Investment }\end{array}$ & $\begin{array}{c}(3) \\
\text { Investment }\end{array}$ \\
\hline Net Buyer & & $\begin{array}{r}0.038 \\
{[0.035]}\end{array}$ & $\begin{array}{c}-0.065^{*} \\
{[0.033]}\end{array}$ \\
\hline Net Buyer*Cash & & & $\begin{array}{r}3.868 * * * \\
{[0.988]}\end{array}$ \\
\hline Cash & $\begin{array}{c}1.560 * \\
{[0.930]}\end{array}$ & $\begin{array}{r}1.414 \\
{[0.869]}\end{array}$ & $\begin{array}{r}-0.234 \\
{[0.540]}\end{array}$ \\
\hline $\ln ($ Size $)$ & $\begin{array}{r}0.010 \\
{[0.011]}\end{array}$ & $\begin{array}{c}0.023^{*} \\
{[0.012]}\end{array}$ & $\begin{array}{r}0.023 * * \\
{[0.011]}\end{array}$ \\
\hline Debt Ratio & $\begin{array}{r}-0.203 * * \\
{[0.096]}\end{array}$ & $\begin{array}{r}-0.121 \\
{[0.124]}\end{array}$ & $\begin{array}{r}-0.142 \\
{[0.116]}\end{array}$ \\
\hline Firm Age & $\begin{array}{r}-0.004 * * * \\
{[0.001]}\end{array}$ & $\begin{array}{r}-0.003 * * \\
{[0.001]}\end{array}$ & $\begin{array}{r}-0.002 * * * \\
{[0.001]}\end{array}$ \\
\hline Property Type $Q$ & $\begin{array}{r}0.223 * * * \\
{[0.074]}\end{array}$ & $\begin{array}{r}0.122 \\
{[0.227]}\end{array}$ & $\begin{array}{r}0.103 \\
{[0.232]}\end{array}$ \\
\hline Constant & Yes & Yes & Yes \\
\hline Property Type & No & Yes & Yes \\
\hline Year Dummies & No & Yes & Yes \\
\hline $\begin{array}{l}\text { Observations } \\
\text { R-suyared }\end{array}$ & 606 & 606 & $\begin{array}{r}606 \\
0.27\end{array}$ \\
\hline & & & \\
\hline
\end{tabular}




\begin{tabular}{|c|c|c|c|}
\hline \multicolumn{4}{|c|}{ Panel C - Long Holder } \\
\hline VARIABLES & $\begin{array}{c}(1) \\
\text { Investment }\end{array}$ & $\begin{array}{c}(2) \\
\text { Investment }\end{array}$ & $\begin{array}{c}(3) \\
\text { Investment }\end{array}$ \\
\hline Long Holder & & $\begin{array}{r}0.046 \\
{[0.034]}\end{array}$ & $\begin{array}{r}-0.013 \\
{[0.035]}\end{array}$ \\
\hline Long Holder*Cash & & & $\begin{array}{l}3.023^{*} \\
{[1.576]}\end{array}$ \\
\hline Cash & $\begin{array}{r}0.643 \\
{[0.810]}\end{array}$ & $\begin{array}{r}0.736 \\
{[0.811]}\end{array}$ & $\begin{array}{r}0.166 \\
{[0.549]}\end{array}$ \\
\hline $\ln$ (Size) & $\begin{array}{r}0.016 \\
{[0.012]}\end{array}$ & $\begin{array}{r}0.034 * * * \\
{[0.010]}\end{array}$ & $\begin{array}{r}0.032 * * * \\
{[0.011]}\end{array}$ \\
\hline Debt Ratio & $\begin{array}{r}-0.075 \\
{[0.080]}\end{array}$ & $\begin{array}{c}0.201 * \\
{[0.118]}\end{array}$ & $\begin{array}{c}0.205^{* *} \\
{[0.101]}\end{array}$ \\
\hline Firm Age & $\begin{array}{r}-0.003 * * \\
{[0.001]}\end{array}$ & $\begin{array}{r}-0.003 * * \\
{[0.001]}\end{array}$ & $\begin{array}{c}-0.002^{*} \\
{[0.001]}\end{array}$ \\
\hline Property Type $Q$ & $\begin{array}{r}0.260 * * * \\
{[0.098]}\end{array}$ & $\begin{array}{r}0.250 \\
{[0.337]}\end{array}$ & $\begin{array}{r}0.264 \\
{[0.334]}\end{array}$ \\
\hline Constant & Yes & Yes & Yes \\
\hline Property Type & No & Yes & Yes \\
\hline Year Dummies & No & Yes & Yes \\
\hline Observations & 390 & 390 & 390 \\
\hline R-squared & 0.07 & 0.20 & 0.24 \\
\hline
\end{tabular}

Notes: Table 3.2 presents the results of OLS regressions of investment activity on overconfidence measures and other controls. Overconfidence is either defined using the net buyer dummy or the long holder dummy. Panel A shows regressions on the net buyer dummy with a sample of REITs with at least 2 CEO-years. Panel B shows regressions on the net buyer dummy with a sample of REITs with at least 5 CEO-years. Panel $C$ shows regressions on the long holder dummy. We use a set of controls including the cash to total assets ratio at the end of previous year, debt to total assets ratio at the end of previous year, logarithm of total assets as a proxy for firm size, firm age, property type dummies and year dummies. We also include the mean of firm-specific $\mathrm{Q}$ by property type by year at the end of the previous year. The data ranges from 2004 to 2010. Heteroskedasticity robust and firm-clustered standard errors are in brackets. * indicates significance at the 10 percent level. $* *$ indicates significance at the 5 percent level. *** indicates significance at the 1 percent level.

In Column 2 and 3 of Table 3.2, we show the results of the regression with the net buyer and long holder dummies with various sample specifications. 
In Panel $A$, we use a sample of REITs with at least 2 CEO-years. The regression excludes observations when stock trading of a CEO is observable in only one year. In model 2 , we find a significantly positive association of the net buyer dummy with investment. However, the overconfidence dummy, while having the expected sign, is not statistically in Panel B with the sample of REITs with at least 5 CEO-years and in Panel C with the long holder sample.

Model 3 also includes the interaction of the overconfidence dummy with cash to assets. We expect that an overconfident manager will overinvest relative to his non-overconfident counterparts if he has enough discretionary cash available. In all three models, we significantly find a positive coefficient for the interaction term. In model 3 of all panels, we find that when the manager is overconfident, a one percent increase in cash to assets leads to a 3-3.9 percent increase in investments.

\subsubsection{Acquisition and Disposition Activity}

Following Glaser and Weber (2007), we separate corporate investment activity into corporate purchasing and sales activity. We estimate corporate acquisition and disposition activity using number of properties. The estimation results for acquisition activity are presented in Table 3.3. Again, Column 1 shows the regressions with financial controls. The effects of financial controls are similar to investment equations. We significantly find that overconfident CEOs annually purchase 3.5-4.3 percent more properties of their available portfolio than non-overconfident counterparts if overconfidence is measured by the net buyer dummy in Panel A and Panel B. The long holder dummy is positive but insignificant in Panel $\mathrm{C}$.

In Column 3 of Table 3.3, we also include the overconfidence-cash interaction term. In all specifications we find that when a CEO is overconfident, a one percent increase in cash to assets increase investments by 1.2-1.7 percent. In other words, when overconfident CEOs have enough discretionary cash, they visit real estate markets more frequently to make investments.

Table 3.4 shows the results for disposition activity of REITs. Model 1 shows the regression results from the estimation of disposition activity on financial controls. We only find a significantly positive effect of debt to assets ratio on 
disposition activity, so REITs that are highly leveraged sell properties more frequently, which may be explained by a need to reduce debt. The other controls do not significantly explain disposition activity different from acquisition activity, which is in line with Glaser and Weber (2007).

In Column 2, we find an insignificant effect of overconfidence on disposition activity. Model 3 also includes the overconfidence-cash interaction term. Using the net buyer dummy, we find that overconfident CEOs sell less than their non-overconfident counterparts if they have more cash. Economically, a one percent increase in cash to assets decreases disposition activity by 0.17-0.18 percent if the manager is overconfident. In Panel C, we also find a negative coefficient for the interaction term but it is not statistically significant.

The reason for a negative impact of CEO overconfidence on property sales when they have enough discretionary cash may be that as the overconfident CEO believes that his decisions bring positive outcomes, he postpones selling the property until the outcome reaches the desired value. The desired value of the asset may be higher than the current market price, and a nonoverconfident CEO may be willing to wait for the asset to reach the target price. As a result, they sell less frequently. 
Table 3.3

The Effect of CEO Overconfidence on Acquisition Activity

\begin{tabular}{|c|c|c|c|}
\hline \multicolumn{4}{|c|}{ Panel A - Net Buyer (At Least 1 CEO-Year) } \\
\hline VARIABLES & $\begin{array}{c}(1) \\
\text { Acquisition }\end{array}$ & $\begin{array}{c}(2) \\
\text { Acquisition }\end{array}$ & $\begin{array}{c}\text { (3) } \\
\text { Acquisition }\end{array}$ \\
\hline Net Buyer & & $\begin{array}{c}0.043^{* *} \\
{[0.018]}\end{array}$ & $\begin{array}{r}0.008 \\
{[0.018]}\end{array}$ \\
\hline Net Buyer*Cash & & & $\begin{array}{r}1.218 * * * \\
{[0.358]}\end{array}$ \\
\hline Cash & $\begin{array}{r}1.360 * * * \\
{[0.283]}\end{array}$ & $\begin{array}{r}1.300 * * * \\
{[0.268]}\end{array}$ & $\begin{array}{r}0.476 \\
{[0.343]}\end{array}$ \\
\hline $\ln ($ Size $)$ & $\begin{array}{r}-0.002 \\
{[0.005]}\end{array}$ & $\begin{array}{r}0.007 \\
{[0.006]}\end{array}$ & $\begin{array}{r}0.007 \\
{[0.005]}\end{array}$ \\
\hline Debt Ratio & $\begin{array}{r}-0.010 \\
{[0.056]}\end{array}$ & $\begin{array}{r}0.040 \\
{[0.058]}\end{array}$ & $\begin{array}{r}0.034 \\
{[0.058]}\end{array}$ \\
\hline Firm Age & $\begin{array}{r}-0.002 * * * \\
{[0.001]}\end{array}$ & $\begin{array}{r}-0.001 * * \\
{[0.001]}\end{array}$ & $\begin{array}{r}-0.001 * * \\
{[0.001]}\end{array}$ \\
\hline Property Type $Q$ & $\begin{array}{r}0.142^{* * *} \\
{[0.040]}\end{array}$ & $\begin{array}{r}0.115 \\
{[0.105]}\end{array}$ & $\begin{array}{r}0.095 \\
{[0.104]}\end{array}$ \\
\hline Constant & Yes & Yes & Yes \\
\hline Property Type & No & Yes & Yes \\
\hline Year Dummies & No & Yes & Yes \\
\hline Observations & 759 & 759 & 759 \\
\hline R-squared & 0.20 & 0.28 & 0.30 \\
\hline Panel B - Net & Buyer (At & Least 5 CEO & -Years) \\
\hline VARIABLES & $\begin{array}{c}\text { (1) } \\
\text { Acquisition }\end{array}$ & $\begin{array}{c}(2) \\
\text { Acquisition }\end{array}$ & $\begin{array}{c}\text { (3) } \\
\text { Acquisition }\end{array}$ \\
\hline Net Buyer & & $\begin{array}{c}0.035^{*} \\
{[0.021]}\end{array}$ & $\begin{array}{r}-0.016 \\
{[0.017]}\end{array}$ \\
\hline Net Buyer*Cash & & & $\begin{array}{r}1.752 * * * \\
{[0.285]}\end{array}$ \\
\hline Cash & $\begin{array}{r}1.329 * * * \\
{[0.335]}\end{array}$ & $\begin{array}{r}1.263 * * * \\
{[0.326]}\end{array}$ & $\begin{array}{r}-0.012 \\
{[0.298}\end{array}$ \\
\hline $\ln ($ Size $)$ & $\begin{array}{r}-0.001 \\
{[0.006]}\end{array}$ & $\begin{array}{r}0.008 \\
{[0.007]}\end{array}$ & $\begin{array}{r}0.007 \\
{[0.005]}\end{array}$ \\
\hline Debt Ratio & $\begin{array}{r}-0.057 \\
{[0.063]}\end{array}$ & $\begin{array}{r}0.013 \\
{[0.068]}\end{array}$ & $\begin{array}{r}-0.014 \\
{[0.067]}\end{array}$ \\
\hline Firm Age & $\begin{array}{r}-0.002 * * \\
{[0.001]}\end{array}$ & $\begin{array}{r}-0.002 * * \\
{[0.001]}\end{array}$ & $\begin{array}{r}-0.001 * * \\
{[0.001]}\end{array}$ \\
\hline Property Type $Q$ & $\begin{array}{r}0.121 * * * \\
{[0.044]}\end{array}$ & $\begin{array}{r}0.019 \\
{[0.113]}\end{array}$ & $\begin{array}{r}-0.007 \\
{[0.114]}\end{array}$ \\
\hline Constant & Yes & Yes & Yes \\
\hline Property Type & No & Yes & Yes \\
\hline Year Dummies & No & Yes & Yes \\
\hline $\begin{array}{l}\text { Observations } \\
\text { R-squared }\end{array}$ & $\begin{array}{r}598 \\
0.20\end{array}$ & $\begin{array}{r}598 \\
0.28\end{array}$ & $\begin{array}{l}598 \\
0.33\end{array}$ \\
\hline
\end{tabular}




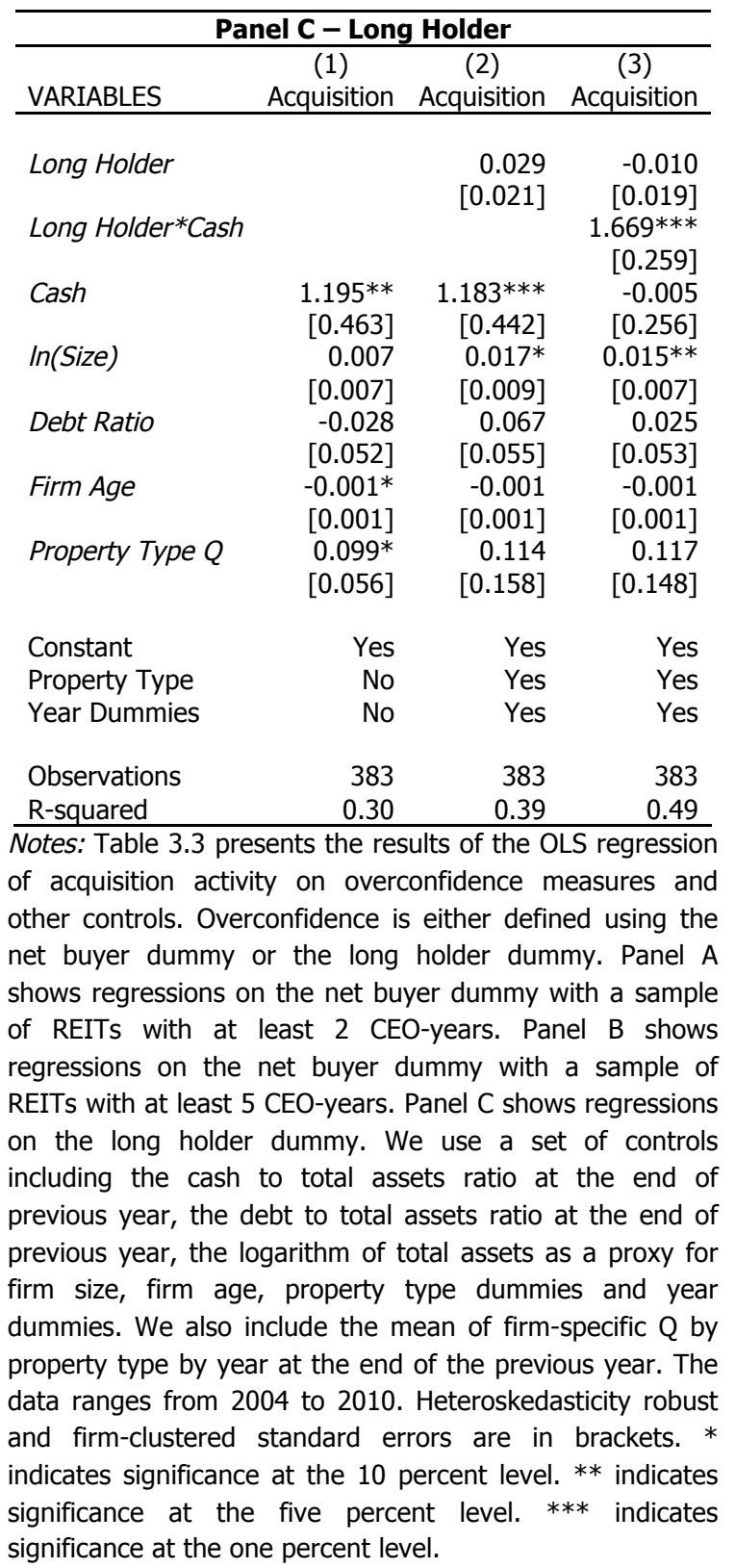


Table 3.4

The Effect of CEO Overconfidence on Disposition Activity

\begin{tabular}{|c|c|c|c|}
\hline \multicolumn{4}{|c|}{ Panel A - Net Buyer (At Least 1 CEO-Year) } \\
\hline VARIABLES & $\begin{array}{c}(1) \\
\text { Disposition }\end{array}$ & $\begin{array}{c}(2) \\
\text { Disposition }\end{array}$ & $\begin{array}{c}\text { (3) } \\
\text { Disposition }\end{array}$ \\
\hline Net Buyer & & $\begin{array}{r}0.007 \\
{[0.010]}\end{array}$ & $\begin{array}{r}0.012 \\
{[0.010]}\end{array}$ \\
\hline Net Buyer*Cash & & & $\begin{array}{l}-0.171^{*} \\
{[0.103]}\end{array}$ \\
\hline Cash & $\begin{array}{r}0.047 \\
{[0.060]}\end{array}$ & $\begin{array}{r}0.033 \\
{[0.077]}\end{array}$ & $\begin{array}{r}0.149 \\
{[0.097]}\end{array}$ \\
\hline $\ln$ (Size) & $\begin{array}{r}0.000 \\
{[0.006]}\end{array}$ & $\begin{array}{r}-0.000 \\
{[0.006]}\end{array}$ & $\begin{array}{r}-0.000 \\
{[0.006]}\end{array}$ \\
\hline Debt Ratio & $\begin{array}{r}0.087 * * \\
{[0.040]}\end{array}$ & $\begin{array}{c}0.084 * \\
{[0.044]}\end{array}$ & $\begin{array}{c}0.085^{*} \\
{[0.044]}\end{array}$ \\
\hline Firm Age & $\begin{array}{r}-0.000 \\
{[0.000]}\end{array}$ & $\begin{array}{r}0.000 \\
{[0.000]}\end{array}$ & $\begin{array}{r}0.000 \\
{[0.000]}\end{array}$ \\
\hline Property Type $Q$ & $\begin{array}{r}0.011 \\
{[0.018]}\end{array}$ & $\begin{array}{r}-0.049 \\
{[0.044]}\end{array}$ & $\begin{array}{r}-0.046 \\
{[0.045]}\end{array}$ \\
\hline Constant & Yes & Yes & Yes \\
\hline Property Type & No & Yes & Yes \\
\hline Year Dummies & No & Yes & Yes \\
\hline Observations & 759 & 759 & 759 \\
\hline R-squared & 0.02 & 0.08 & 0.08 \\
\hline Panel B - Net & Buyer (At & Least 5 CEO & -Years) \\
\hline VARIABLES & $\begin{array}{c}(1) \\
\text { Disposition }\end{array}$ & $\begin{array}{c}\text { (2) } \\
\text { Disposition }\end{array}$ & $\begin{array}{c}\text { (3) } \\
\text { Disposition }\end{array}$ \\
\hline Net Buyer & & $\begin{array}{r}0.006 \\
{[0.011]}\end{array}$ & $\begin{array}{r}0.012 \\
{[0.012]}\end{array}$ \\
\hline Net Buyer*Cash & & & $\begin{array}{l}-0.182 * \\
{[0.106]}\end{array}$ \\
\hline Cash & $\begin{array}{r}0.070 \\
{[0.070]}\end{array}$ & $\begin{array}{r}0.043 \\
{[0.082]}\end{array}$ & $\begin{array}{r}0.176 \\
{[0.109]}\end{array}$ \\
\hline $\ln$ (Size) & $\begin{array}{r}0.001 \\
{[0.007]}\end{array}$ & $\begin{array}{r}0.001 \\
{[0.007]}\end{array}$ & $\begin{array}{r}0.001 \\
{[0.007]}\end{array}$ \\
\hline Debt Ratio & $\begin{array}{c}0.084 * \\
{[0.046]}\end{array}$ & $\begin{array}{r}0.089 \\
{[0.056]}\end{array}$ & $\begin{array}{r}0.092 \\
{[0.056]}\end{array}$ \\
\hline Firm Age & $\begin{array}{r}0.000 \\
{[0.000]}\end{array}$ & $\begin{array}{r}0.000 \\
{[0.000]}\end{array}$ & $\begin{array}{r}0.000 \\
{[0.000]}\end{array}$ \\
\hline Property Type $Q$ & $\begin{array}{r}0.023 \\
{[0.019]}\end{array}$ & $\begin{array}{r}-0.045 \\
{[0.049]}\end{array}$ & $\begin{array}{r}-0.042 \\
{[0.050]}\end{array}$ \\
\hline Constant & Yes & Yes & Yes \\
\hline Property Type & No & Yes & Yes \\
\hline Year Dummies & No & Yes & Yes \\
\hline $\begin{array}{l}\text { Observations } \\
\text { R-squared }\end{array}$ & $\begin{array}{r}598 \\
0.02\end{array}$ & $\begin{array}{r}598 \\
0.08\end{array}$ & $\begin{array}{l}598 \\
0.09\end{array}$ \\
\hline
\end{tabular}




\begin{tabular}{lrrr}
\hline \multicolumn{4}{c}{ Panel C - Long Holder } \\
\hline & \multicolumn{1}{c}{$(1)$} & \multicolumn{1}{c}{$(2)$} & \multicolumn{1}{c}{$(3)$} \\
VARIABLES & Disposition & Disposition & Disposition \\
\hline & & & \\
Long Holder & & -0.003 & -0.000 \\
& & {$[0.014]$} & {$[0.015]$} \\
Long Holder*Cash & & & -0.133 \\
& & & {$[0.090]$} \\
Cash & -0.045 & -0.069 & 0.025 \\
& {$[0.049]$} & {$[0.060]$} & {$[0.113]$} \\
In(Size) & -0.002 & 0.000 & 0.000 \\
& {$[0.005]$} & {$[0.004]$} & {$[0.004]$} \\
Debt Ratio & 0.024 & 0.010 & 0.014 \\
& {$[0.034]$} & {$[0.038]$} & {$[0.039]$} \\
Firm Age & 0.001 & 0.001 & 0.001 \\
& {$[0.001]$} & {$[0.001]$} & {$[0.001]$} \\
Property Type $Q$ & -0.013 & -0.090 & -0.090 \\
& {$[0.025]$} & {$[0.063]$} & {$[0.064]$} \\
Constant & & & \\
Property Type & Yes & Yes & Yes \\
Year Dummies & No & Yes & Yes \\
& No & Yes & Yes \\
Observations & & & \\
R-squared & 383 & 383 & 383 \\
\hline
\end{tabular}

Notes: Table 3.4 presents the results of OLS regression of disposition activity on overconfidence measures and other controls. Overconfidence is either defined using $\backslash$ net buyer dummy or long holder dummy. Panel A shows regressions on the net buyer dummy with a sample of REITs with at least 2 CEO-years. Panel B shows regressions on the net buyer dummy with a sample of REITs with at least 5 CEOyears. Panel $C$ shows regressions on the long holder dummy. We use a set of controls including the cash to total assets ratio at the end of previous year, debt to total assets ratio at the end of previous year, logarithm of total assets as a proxy for firm size, firm age, property type dummies and year dummies. We also include the mean of firmspecific $\mathrm{Q}$ by property type by year at the end of the previous year. The data ranges from 2004 to 2010. Heteroskedasticity robust and firm-clustered standard errors are in brackets. ${ }^{*}$ indicates significance at the 10 percent level. ** indicates significance at the 5 percent level. ${ }^{* * *}$ indicates significance at the 1 percent level.

Overall, we find that overconfident REIT CEOs purchase more and sell fewer properties when they have enough available cash. This could be driven by 
empire-building behavior. Overconfident CEOs increase the portfolio size of their companies more than other REIT CEOs by purchasing more and selling less. In unreported regressions, we define a net acquisition variable, which is the difference of acquisition activity and disposition activity. In all specifications, we find that the interaction term is significantly positive within a one percent significance level.

\subsection{CEO Overconfidence and Corporate Performance}

According to Malmendier and Tate (2005a), it is important to evaluate private information and separate it from CEO overconfidence. We claim that a CEO is overconfident if he buys more of his own stocks than he sells, or if he does not exercise his company stock options in a rational manner. If these acts are indeed signs of overconfidence, than we expect that the overinvestment of these REITs will lead to underperformance, following Barber and Odean (2001).

However, these acts may also be signs of a CEO's access to valuable private information. The CEO may then increase stock ownership and retain options to rationally enhance individual wealth, or he may be willing to signal this positive information. In both cases, we would see an association with increased performance.

One further difference between overconfident behavior and positive private information is that CEO behavior related to positive private information is likely to be short-term: positive private information is unlikely to be present in equal proportion at all time. However, overconfidence is habitual and as a result, it is persistent. This is why we define a manager as overconfident when he is more often overconfident than otherwise.

To look at whether CEOs stock purchases are related to positive private information, we create a dummy variable, which gets a value of one when a CEO is a net buyer of his own company stock in that particular year. In this way, we have a short-term net buyer measure and since we also lag it, we are then able to observe the short-term consequences of being a net buyer and see whether being a net buyer is related to positive private information. 
Table 3.5

\section{CEO Overconfidence and Corporate Performance}

\begin{tabular}{|c|c|c|c|c|c|c|}
\hline VARIABLES & $\begin{array}{c}(1) \\
\text { In(Firm Q) }\end{array}$ & $\begin{array}{c}(2) \\
\ln (\text { Firm Q) }\end{array}$ & $\begin{array}{c}(3) \\
\ln (\text { Firm Q) }\end{array}$ & $\begin{array}{c}(4) \\
\ln (\mathrm{ROA}) \\
\end{array}$ & $\begin{array}{c}(5) \\
\ln (\mathrm{ROA}) \\
\end{array}$ & $\begin{array}{c}(6) \\
\ln (\mathrm{ROA}) \\
\end{array}$ \\
\hline $\begin{array}{l}\text { Net Buyer } \\
\text { (dynamic- } \\
\text { lagged) }\end{array}$ & $\begin{array}{c}-0.032 * \\
{[0.017]}\end{array}$ & & & $\begin{array}{r}-0.072 \\
{[0.065]}\end{array}$ & & \\
\hline $\begin{array}{l}\text { Net Buyer*Cash } \\
\text { (dynamic- } \\
\text { lagged) }\end{array}$ & $\begin{array}{r}-0.118 \\
{[0.231]}\end{array}$ & & & $\begin{array}{r}-1.483 * * \\
{[0.742]}\end{array}$ & & \\
\hline Net Buyer & & $\begin{array}{r}-0.009 \\
{[0.044]}\end{array}$ & & & $\begin{array}{r}-0.090 \\
{[0.129]}\end{array}$ & \\
\hline Net Buyer*Cash & & $\begin{array}{c}-0.731 * \\
{[0.369]}\end{array}$ & & & $\begin{array}{r}-3.185 * * * \\
{[1.022]}\end{array}$ & \\
\hline Long Holder & & & $\begin{array}{r}0.072 \\
{[0.067]}\end{array}$ & & & $\begin{array}{r}0.109 \\
{[0.190]}\end{array}$ \\
\hline $\begin{array}{l}\text { Long } \\
\text { Holder*Cash }\end{array}$ & & & -0.291 & & & $-2.275^{* *}$ \\
\hline & & & [0.436] & & & [0.988] \\
\hline Cash & $\begin{array}{r}0.138 \\
{[0.263]}\end{array}$ & $\begin{array}{c}0.722^{* *} \\
{[0.340]}\end{array}$ & $\begin{array}{r}0.387 \\
{[0.438]}\end{array}$ & $\begin{array}{r}-0.080 \\
{[0.806]}\end{array}$ & $\begin{array}{c}1.754 * \\
{[0.965]}\end{array}$ & $\begin{array}{r}1.221 \\
{[0.961]}\end{array}$ \\
\hline $\ln ($ Size $)$ & $\begin{array}{r}0.029 * * \\
{[0.014]}\end{array}$ & $\begin{array}{c}0.032 * \\
{[0.017]}\end{array}$ & $\begin{array}{r}0.026 \\
{[0.027]}\end{array}$ & $\begin{array}{r}0.008 \\
{[0.039]}\end{array}$ & $\begin{array}{r}0.002 \\
{[0.040]}\end{array}$ & $\begin{array}{r}0.036 \\
{[0.061]}\end{array}$ \\
\hline Debt Ratio & $\begin{array}{r}-0.135 \\
{[0.115]}\end{array}$ & $\begin{array}{r}-0.111 \\
{[0.139]}\end{array}$ & $\begin{array}{r}-0.148 \\
{[0.174]}\end{array}$ & $\begin{array}{r}-2.644 * * * \\
{[0.316]}\end{array}$ & $\begin{array}{r}-2.177^{* * *} \\
{[0.354]}\end{array}$ & $\begin{array}{r}-2.223 * * * \\
{[0.393]}\end{array}$ \\
\hline Firm Age & $\begin{array}{r}0.005^{* * *} \\
{[0.001]}\end{array}$ & $\begin{array}{r}0.005^{* * *} \\
{[0.002]}\end{array}$ & $\begin{array}{r}0.004 \\
{[0.003]}\end{array}$ & $\begin{array}{r}0.014 * * * \\
{[0.004]}\end{array}$ & $\begin{array}{r}0.012 * * * \\
{[0.004]}\end{array}$ & $\begin{array}{r}0.009 \\
{[0.006]}\end{array}$ \\
\hline Property Type $Q$ & $\begin{array}{r}0.633 * * * \\
{[0.113]}\end{array}$ & $\begin{array}{r}0.530 * * * \\
{[0.122]}\end{array}$ & $\begin{array}{r}0.726 * * * \\
{[0.149]}\end{array}$ & $\begin{array}{r}0.544 \\
{[0.604]}\end{array}$ & $\begin{array}{r}0.671 \\
{[0.592]}\end{array}$ & $\begin{array}{r}2.182 * * \\
{[0.837]}\end{array}$ \\
\hline Constant & Yes & Yes & Yes & Yes & Yes & Yes \\
\hline Property Type & Yes & Yes & Yes & Yes & Yes & Yes \\
\hline Year Dummies & Yes & Yes & Yes & Yes & Yes & Yes \\
\hline Observations & 771 & 607 & 391 & 638 & 510 & 347 \\
\hline R-squared & 0.43 & 0.45 & 0.39 & 0.36 & 0.39 & 0.39 \\
\hline
\end{tabular}

Notes: Table 3.5 presents the results of OLS regression of financial performance defined by logarithm of firm specific $Q$ and logarithm of return of assets on overconfidence measures and other controls. In model 1 and 4, the net buyer dummy is 1 if a CEO is a net buyer in that particular year. In the remaining models, overconfidence is either defined using the net buyer dummy or the long holder dummy. Model 2 and 5 show regressions on the net buyer dummy with a sample of REITs with at least 5 CEO-years. Model 3 and 6 show regressions on the long holder dummy. We use a set of controls including the cash to total assets ratio at the end of the previous year, the debt to total assets ratio, the logarithm of total assets as a proxy for firm size, firm age, property type dummies and year dummies. We also include the mean of firm specific $Q$ by property type by year. The data ranges from 2004 to 2010 . Heteroskedasticity robust and firm-clustered standard errors are in brackets. ${ }^{*}$ indicates significance at the 10 percent level. $* *$ indicates significance at the five percent level. $* * *$ indicates significance at the one percent level. 
In Model 1 and 4 of Table 3.5, we regress financial performance on the dynamic net buyer dummy. As a proxy for financial performance we use the logarithm of firm specific $Q$ and the logarithm of return on assets.

We find that when a CEO is a net buyer in his own company stock in the previous year, firm $Q$ declines by 3 percent. We do not find any significant sensitivity of the relationship to cash to assets. In model 4, we do not find any significant direct effect of being a net buyer in the previous year on the logarithm of return on assets. However, we find that when a CEO is a net buyer in the previous year, a one percent increase in cash to assets leads to 1.5 percent decline in return on assets. Overall, net buyer CEOs do not perform better in the next year, which does not support positive private information, but instead suggests that our stock ownership measures are indeed proxies for overconfidence. ${ }^{15}$

Following Hartzell, Sun, Titman (2006), we also use property type Q in the investment equations, instead of firm specific $Q$ as a proxy for investment opportunities. This helps us to solve a possible endogeneity problem because being overconfident is not economically related to property type $\mathrm{Q}$ but can affect firm specific $Q$ because of overinvestment.

In models 2 and 5, we present the regressions of financial performance on overconfidence defined by the static net buyer dummy. We find that when a CEO is overconfident, a one percent increase in cash to assets decreases firm specific $Q$ by 0.7 percent and return on assets by 3.1 percent. When we define overconfidence by the long holder dummy, the effect on logarithm of firm specific $Q$ becomes insignificant but a one percent increase in cash to assets leads to 2.3 percent decline in return on assets. Overall, we find a negative association between our CEO overconfidence measures and REIT performance when managers have enough discretionary cash, indicating that valuable private information is not the cause of CEO's stock purchasing and option exercise.

\footnotetext{
${ }^{15}$ We also look at the second lag of dynamic net buyer dummy. The results are robust to this alternative specification.
} 


\subsection{Concluding Remarks}

Outside of mutual funds, the effects of behavioral biases of professional managers have not been intensively investigated. This is likely due to the difficulty to identify and track individual decisions of managers. The few exceptions that do investigate the effect of behavioral biases within a corporate setting include most notably the empirical studies by Malmendier and Tate (2005a, b, 2008), Malmendier, Tate, and Yan (2011), and Crane and Hartzell (2008). Malmendier and Tate (2005a) relate overconfidence to investment-cash-flow sensitivity of CEOs and show that CEO overconfidence has a positive effect on investment, which is measured using firm capital expenditures.

Crane and Hartzell (2008) investigate a different behavioral aspect, the disposition effect, using a REIT sample. REITs offer an ideal setting to investigate professional managers' investment decisions. Investment and divestment decisions can easily be identified since REITs mainly purchase and sell buildings, so most of the investment decisions can be followed by the researcher. Additionally, REIT asset values are transparent, making it possible to observe how much a firm spent when investing in a project.

We investigate the effect of CEO overconfidence on corporate investment activity using REITs. Using a REIT sample gives us the opportunity to identify each investment decision and observe how frequently REIT managers invest and to relate corporate investment activity to CEO overconfidence, and additionally do that separately using corporate purchases and sales.

We use two different measures of overconfidence, following Malmendier and Tate (2005a). We define a CEO as overconfident if he is a net buyer of his own company stock more times than he sells throughout the whole sample period. We also determine whether a CEO is overconfident by looking at the exercise of stock options. If a CEO holds his stock option until the expiry year and exercises it in that year and if this happens for that specific manager at least twice, we call the manager as overconfident.

We find that overconfident CEOs significantly invest more than their nonoverconfident counterparts if they have enough discretionary cash. When a CEO is overconfident, we document that a one percent increase in cash to assets significantly leads to 3-4 percent increase in investments. 
Following Glaser and Weber (2007), we additionally look at acquisition and disposition activity. We find that when a CEO is overconfident, a one percent increase in cash to assets increases acquisition activity by 1.2-1.7 percent and decreases disposition activity by 0.2 percent. However, the disposition activity regressions should be explained cautiously since we couldn't find any significant effect of overconfidence on disposition activity when we use the long holder dummy, although the sign of the coefficient is the same.

A CEO who is a net buyer of his own company's stock may indicate CEO overconfidence or access to private information. However, with private information, we expect their companies to perform better, while overconfident CEOs trade non-optimally, which is associated with worse performance. We first define a dynamic net buyer dummy. We find that when a CEO is a net buyer, he does not perform better, and actually even performs worse in the next year. Additionally, we show that REITs led by overconfident CEOs have worse operating performance than their counterparts if they have enough cash available, irrespective of the way we measure overconfidence. 


\section{Chapter 4 \\ Political Preferences and Corporate Sustainability ${ }^{16}$}

\subsection{Introduction}

Sustainable buildings have gained the attention of investors during the last decade, following increasing environmental concerns in society as well as higher energy prices. Accordingly, green certifications schemes such as Energy Star and LEED in the United States and BREEAM in the United Kingdom have started to gain momentum. For example, LEED certified properties, having covered only two percent of new construction in the United States in 2005, made up one third of new construction in 2012.

However, certifications are perceived as costly, and investors have been uncertain about the economic benefits of green certified buildings. Recent studies on the economic implications of sustainable properties (i.e., Eichholtz, Kok, and Quigley, 2010, 2013; Fuerst and McAllister, 2011; Miller, Spivey, and Florance, 2008; and Wiley, Benefield, and Johnson, 2008) show that certified buildings generate premiums in rents and transaction prices. Investigating real estate portfolios, Eichholtz, Kok, and Yönder (2012) document that owning "green" properties increases operating performance and decreases market beta for U.S. Real Estate Investment Trusts (REITs) over the 2000-2010 period.

The research to date has mainly concentrated on the financial performance of green buildings, but there is a limited understanding about the motivations to invest in green properties and the macro factors affecting market take-up. One of the few exceptions is the study by Kok, McGraw and Quigley (2011b), who address the factors affecting the diffusion of green property investments at the macro level. The study investigates the diffusion of green properties across 48 MSAs in the United States over the 1995-2005 period, documenting that MSAs with higher incomes, lower vacancy rates and higher property values become greener. They also find that green building professionals and policies encouraging green properties increase the share of green properties at the MSA level.

${ }^{16}$ Eichholtz, Piet; Nils Kok and Erkan Yönder. 2013. "Political Preferences and Corporate Sustainability: Evidence from REITs," Working Paper. 
In this chapter, we aim to investigate the determinants of green property investments from the owners' perspective. More specifically, we evaluate green property investments by U.S. REITs, for which detailed information on property investments and management attributes is available. Most importantly for this chapter, we are able to identify the political preference of REIT CEOs, allowing us to answer our main research question: the effect of political preference of REIT CEOs on green property investments.

Controlling for financial and local determinants such as the locational greenness of a property, we hypothesize that Democrat-leaning managers are more likely to invest in green properties than Republican-oriented managers. Our hypothesis is based on two notions. First, American politics are strongly partisan when it comes to environmental issues, and Democrats are more prone to follow environmental policies. Hong and Kostovetsky (2012) document that relative to a typical manager of a comparable fund, Democrat-leaning fund managers are less exposed to tobacco, guns and defense, and to natural resources industries. Secondly, Republicans are generally more conservative people and are more reluctant to make new types of investments, probably including investments in green properties. Hutton, Jiang, and Kumar (2011) document that Republican managers follow less risky and more profitable investment strategies and spend less on R\&D compared to Democrat managers.

Using the contributions of REIT managers to candidates during federal elections as a proxy, we find that Democrat-leaning (Republican) CEOs are more (less) likely to invest in green properties, i.e. buildings with "green" certification. Political preferences especially affect the likelihood and intensity of owning Energy-Star labeled buildings. We do not find a relation between the political ideology of a REIT CEO and the REIT's ownership of LEED labeled buildings. REITs whose CEO are strongly Democrat, witnessed by the fact that they only contribute the Democrats, are even less likely to invest in LEED certified buildings than in conventional buildings and Energy Star labeled buildings.

We also find that firm size and the locational greenness of a property matter. Additionally, more experienced CEOs are less likely to invest in green properties and we find that bigger firms are more likely to own LEED labeled buildings. 
These finding may be related to recent discussions on LEED certified buildings. An examination by USA TODAY on 7,100 LEED labeled properties shows that designers aim to earn the easiest and cheapest points. They use common building materials; or implement inexpensive issues such as preferred parking for fuel-efficient cars, bike racks and showers, and posting educational displays about the building. Additionally, LEED certification points for energy efficiency are based on projections, not on actual use, since LEED is awarded before occupancy while the Energy Star program awards buildings on actual energy consumption over a year of occupancy, and rates buildings every year.

The rest of the study preceeds as follows: the next section reviews the literature on green buildings and political preferences and investment behavior. In the third section, we explain the data and show some preliminary analysis. The fourth section presents the method and results of the multivariate analysis, and in the final section we summarize and provide concluding remarks.

\subsection{Literature Review}

\subsubsection{Green Buildings}

The empirical research on the financial performance of green buildings is rapidly evolving. It investigates whether green properties generate economic premiums and whether these properties are profitable to owners such as REITs.

Most of the research on green buildings has been done at the property level. Eichholtz, Kok, and Quigley (2010) investigate the premium generated by LEED and Energy Star certifications on the rents and transaction prices of office buildings in the United States. They find rental premium of 5 and 8 percent for LEED-certified and Energy-Star-rated office buildings, respectively; the premiums in transaction prices are 11 percent and 19 percent, respectively, always controlling for differences in building quality.

Fuerst and McAllister (2011) find similar premiums for both types of certifications in their work, which also concerns United States offices. Other papers on the topic are Miller, Spivey, and Florance (2008) and Wiley, Benefield, and Johnson (2010). These studies mainly differ from each other 
in the samples they use and the methodologies they follow, but they all test economic premiums and show that green buildings have significantly higher rents and asset values than conventional ones after controlling for differences in quality and location.

Eichholtz, Kok, and Quigley (in press) extend the literature by using a much larger sample than previous studies, by applying propensity score weights to properly control for quality differences between the treatment and control samples, and by extending the analysis into the 2009 crisis time. Interestingly they find that the premiums have not changed significantly between 2007 and 2009, despite the large increase in the supply of certified buildings and marked decrease in office demand due to the global financial crisis. They find that rents and occupancy rates of certified buildings still generate higher premiums than those of comparable buildings. They are also able to investigate to what extent the effective rent premiums are comparable to the energy savings for the tenants of green buildings. It turns out that the rent increases 95 cents for a one dollar reduction in the energy bill. This suggests that premiums to green buildings are not a fad, but a result of cold-headed financial considerations.

Besides these building-level papers, there is only limited research at the portfolio level. Eichholtz, Kok, and Yönder (2012) investigate the relation between the performance of United States REITs and the degree to which these hold green properties, as measured by LEED and Energy Star labels. They show that the share of certified properties is positively related to operating performance, and negatively related to systematic risk. A recent study by Bauer et al. (2011) investigates the environmental and financial performance of listed property companies globally. In both studies, the authors find that better environmental performance is associated with better operating performance.

To our knowledge, there is little evidence regarding the motivations of building owners to go sustainable. Despite the recent academic evidence surveyed above, there is still a debate among practitioners regarding the financial benefits of green properties. In a survey (Pivo, 2008) of around 200 CEOs of REITs, real estate operating companies, and property development companies, many of the respondents state that insufficient information on the financial performance of "green" buildings and a lack of tenant demand for environmentally friendly buildings are the main obstacles to invest in certified properties. 
Kok, Bauer, and Eichholtz (2011a) show that larger property companies, especially those from Australia, are superior environmental performers. Additionally, they show that property companies investing in retail and office properties display better environmental performance than companies active in residential and industrial.

At the regional level, Kok, McGraw, and Quigley (2011b) find that MSAs with higher incomes, lower vacancy rates, higher property values, more educated green building professionals and more policies supporting green buildings have a higher share of green building in their overall building stock.

Besides these two papers, it remains a question why some property companies invest in green buildings, while others do not. The literature on green buildings develops mostly around financial performance, but we know little about who chooses to invest in green buildings.

\subsubsection{Political Preference and Investment Behavior}

In the broader finance literature, recent research suggests that one of the drivers of corporate investment decisions is the political preference of managers and individual investors. Hutton, Jiang, and Kumar (2011) examine whether Republican corporate managers - who are expected to be more conservative than their democratic peers - also follow conservative polices at their companies. They show that Republican managers implement less risky and more profitable investments and have lower R\&D expenditures. Their companies also have lower leverage and pay higher dividends.

Hong and Kostovetsky (2012) investigate whether political values affect socially responsible investment decisions, looking at mutual fund managers. Following the literature, they test the idea that Democrats are more prone to follow environmental and labor protection policies and are more likely to be against smoking, guns, and defense rather than Republicans. They document that Democrat fund managers are less exposed to companies active in the tobacco, guns and defense, and natural resources industries: about one percentage point less than a typical fund manager of a comparable fund. Interestingly, the Democrat and Republican fund managers' investment performance is better than non-donors but not significantly different from each other. 
Di Giuli and Kostovetsky (2011) investigate the relationship between political preferences of stakeholders as a proxy for socially responsible behaviour and CSR. They show that Democratic CEOs, founders and directors are associated with higher firm CSR ratings as measured by KLD scores. Additionally, they document that if the headquarter of their firm is located in a Democratic region the company is shown to be more socially responsible. In their analysis, they control for firm characteristics as well as CEO characteristics such as CEO age.

Other recent studies in the finance literature also show that political preference of individuals affect their investment style (Bonaparte, Kumar, and Page, 2010; Kaustia and Torstila, 2011).

\subsection{Data and Univariate Analysis}

\subsubsection{Measuring Portfolio Greenness}

Following Eichholtz, Kok, Yönder (2012) and the existing literature, we define a property as "green" if it is Energy Star labeled by the Environmental Protection Agency (EPA) or LEED certified by the US Green Building Council.

The Energy Star program was initiated in 1992 by the U.S. Environment Protection Agency (EPA) and the U.S. Department of Energy (DOE). The label solely concentrates on energy consumption by evaluating energy consumption and the efficiency of buildings' energy use relative to a comparable building. Since the Energy Star program assesses energy consumption, it can only be applied to buildings in use, which is different from the LEED label.

Since 1999, residential and office buildings have been certified with the Energy Star label, and the EPA currently also labels retail properties, hotels, and warehouses. According to Eichholtz, Kok, and Yönder (2012) 15,146 commercial properties had received an Energy Star label as of August 2011.

The other main certification program for green buildings in the United States is the LEED program developed by the U.S. Green Building Council (USGBC) in 1998. The certification program evaluates sustainability within six categories and encourages improving the performance and the design of the buildings across energy consumption, water use, $\mathrm{CO}_{2}$ emissions, indoor 
environmental quality, and stewardship of resources.

Although the take-up of the LEED label was slow initially, the growth of the LEED label has recently accelerated. While two percent of new construction was LEED labeled in 2005, this has increased to one third in 2012. The total number of LEED-certified commercial buildings as of August 2011 was 10,121 (Eichholtz, Kok, and Yönder, 2012).

To measure the "greenness" of REIT property portfolios, we follow the method proposed by Eichholtz, Kok, and Yönder (2012). SNL Financial provides data on all properties in the portfolios of U.S. REITs. We use a GIS script to obtain the longitude and the latitude of each property in the database, and then match them to the files maintained by the EPA and USGBC to determine whether these buildings are Energy Star and/or LEED certified, respectively. Considering the year of certification from the EPA and USGBC databases, and the year of acquisition and/or sale from the SNL database, we calculate green property shares in the property portfolio for each year for each REIT. This way, we create an annual measure of property portfolio greenness. The equation we calculate to construct greenness measure is as follows:

(4.1) Greenness it $^{g}=\frac{\sum_{/} \text {Sqft of Certified Property }}{\sum_{\text {ilt }}}$

where

$i$ stands for REIT $i, t$ stands for year $t$, / stands for property $/$ and $g$ is the certification, which is either LEED or Energy Star.

Figure 4.1 shows the evolution of green building shares in property portfolios of REITs. The figure shows the average portfolio greenness among REITs owning labeled properties and the portfolio greenness of the greenest REIT each year. 
Figure 4.1

\section{Evolution of Green Property Ownership}
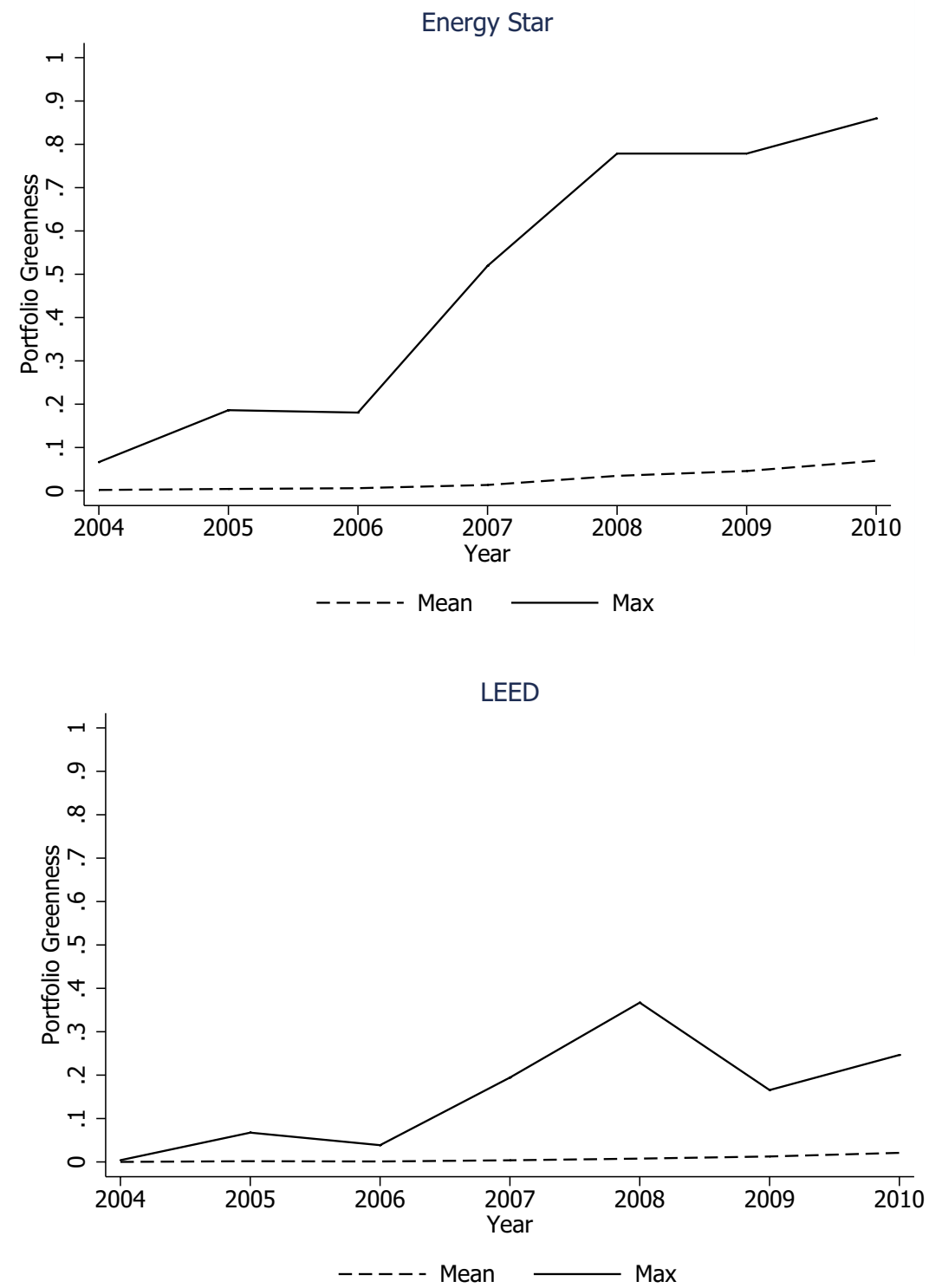

Notes: The figure shows average shares of properties with Energy Star and LEED certifications in annual REIT property portfolios. The REITs with maximum Energy Star and LEED shares are also presented. 
In 2004, we observe that there are very few certified buildings owned by REITs. But while there apparently is no green property culture among REITs in the first half of the last decade, we observe an increasing trend in the second half. We see a faster increase in the portfolio shares of Energy Star labeled properties than of LEED labeled properties.

We also look at the portfolio greenness of the greenest REITs each year. Until 2004, the share of Energy Star labeled properties in the greenest REIT's property portfolio was less than 10 percent, but this has increased to more than 80 percent in 2010. The share for LEED was zero in 2004 and we see a slower increase than in Energy Star take-up. The share of LEED labeled properties in the portfolio of the greenest REIT was 20-30 percent by the end of the decade.

Overall, green property investment seems to have taken off very recently among REITs and we are still at the very early stages of this. The numbers presented in Figure 4.1 suggest that REITs prefer to own Energy Star labeled properties rather than LEED certified properties, since the increase in portfolio shares is faster for Energy Star labeled properties. One reason for this might be that Energy Star is more related to the energy consumption of buildings, which is more closely related to the bottom line than the LEED program, which has a more complex and holistic approach.

\subsubsection{Measuring Political Preferences}

To determine the political preference of REIT CEOs, we collect data from the Federal Elections Committee (FEC) website ${ }^{17}$. The FEC records data on political contributions to the candidates and to the political action committees (PACs) during federal elections by any individual since 1979. It also presents data on donors' home address and employer. We manually search for the name of each REIT CEO using REIT annual reports, and then match this with the FEC records to identify contributions by each CEO to candidates and PACs. For each contribution, we collect information on recipient such as state, associated party (if available) and date and contribution to the recipient.

If a candidate or a PAC to which a REIT CEO has contributed is associated

${ }^{17}$ For more information, please visit www.fec.gov. 
with a party in the FEC database, we assume that the REIT CEO contributes to the associated party. Additionally, for the PACs that are not associated with a party in the FEC database, we look at the candidates who are supported by those committees. We label a PAC with a party if at least twothirds of the candidates it contributes to are associated with the same party. ${ }^{18}$ Once we have determined the candidates' and PACs' associations with the political parties, we sum up the dollar value of contributions for Democratic/Republican candidates and committees for each REIT CEO. To measure political preference, we use the following equation:

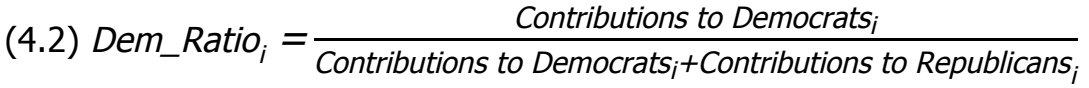

where

$i$ stands for The CEO of REIT $i$.

If a REIT CEO only contributes to Democrats, Dem_Ratio is one, while a REIT CEO who only contributes to Republicans has a Dem_Ratio of zero. The value of Dem_Ratio for non-donors is 0.5 . As the CEO becomes more Democratic, Dem_Ratio increases.

Figure 4.2 presents the histogram of Dem_Ratio. Overall, we see that REIT CEOs tend to be Republicans. The mean is around 0.4 , which is in the Republican region. The frequency at the tails is larger in the Republican region than in Democrat region, which is in line with our expectations: the real estate industry is a rather conservative industry and Republicans are more likely to be conservative. Besides that, there are two other interesting observations to be made in Figure 4.2. First, we see that the ratio spikes in the middle, suggesting opportunistic behavior in the political contributions of REIT CEOs. Second, we see spikes at the extremes on the distribution, implying strong political convictions, but on the other hand, these spikes are not very high, and their mass does not dominate the distribution.

\footnotetext{
${ }^{18}$ We find similar results if we exclude those committees which are not associated with a party in the FEC database.
} 
Figure 4.2

\section{Histogram of Dem_Ratio}

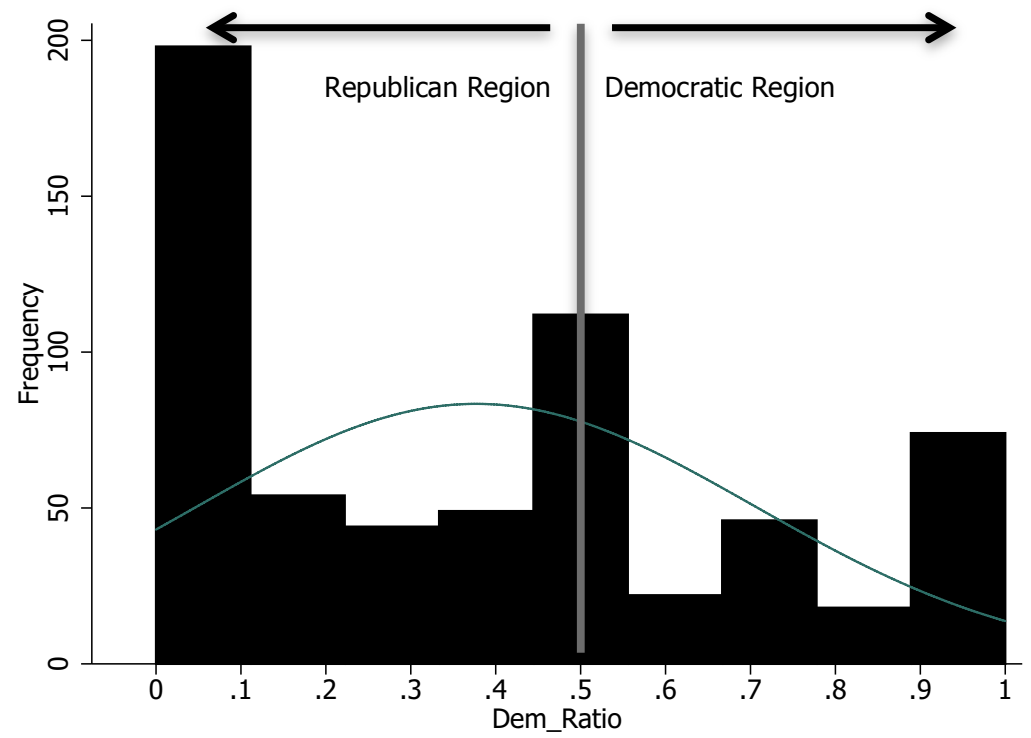

Notes: The figure shows the distribution of the ratio of contributions to Democrats to total contributions during federal elections (Dem_Ratio) by REIT CEOs. Values of Dem_Ratio larger than 0.5 represent CEOs more contributing to Democrats while values smaller than 0.5 represent CEOs more contributing to Republicans.

To measure the effect of strong political convictions on sustainable investment decisions, we also look specifically at strong Democrats and strong Republicans. We create two dummy variables, Dem_Dummy and Rep_Dummy for REIT CEOs who only contribute to one of the parties. Dem_Dummy gets one if Dem_Ratio is equal to one while Rep_Dummy gets one if Dem_Ratio is equal to zero.

Table 4.1 gives initial statistics regarding the portfolio greenness of REITs whose CEOs are either strong Democrats or strong Republicans. The table shows the descriptive statistics of Energy Star and LEED shares for Democrats, Republicans and others including non-donors. From strong Republicans to the middle group, and from the middle group to strong Democrats, we see that there is an increasing trend in the property portfolio shares of Energy Star certified buildings. 
Table 4.1

\section{Portfolio Greenness by Strong Democrats/Republicans}

\begin{tabular}{|c|c|c|c|c|c|c|}
\hline & \multicolumn{6}{|c|}{ Energy Star } \\
\hline & Obs & Mean & Std. Dev. & Min & Max & Dem-Rep \\
\hline Dem_Dummy & 38 & 0.075 & 0.196 & 0.000 & 0.860 & $0.066 * *$ \\
\hline Others & 498 & 0.025 & 0.089 & 0.000 & 0.779 & \\
\hline \multirow[t]{3}{*}{ Rep_Dummy } & 81 & 0.009 & 0.035 & 0.000 & 0.266 & \\
\hline & & & & & & LEED \\
\hline & Obs & Mean & Std. Dev. & Min & Max & Dem-Rep \\
\hline Dem_Dummy & 38 & 0.000 & 0.000 & 0.000 & 0.000 & $-0.007 * * *$ \\
\hline Others & 498 & 0.008 & 0.031 & 0.000 & 0.367 & \\
\hline Rep_Dummy & 81 & 0.007 & 0.020 & 0.000 & 0.116 & \\
\hline \multicolumn{7}{|c|}{$\begin{array}{l}\text { Notes: Table } 4.1 \text { shows shares of properties with Energy Star and LEED } \\
\text { certifications in REIT annual property portfolios by strong Democrats } \\
\text { (Dem_Dummy) who only contribute to Democratic candidates and } \\
\text { strong Republicans (Rep_Dummy) who only contribute to Republican } \\
\text { candidates during federal elections. The last column shows the } \\
\text { difference in Energy Star and LEED shares for strong Democrats and } \\
\text { strong Republicans. }\end{array}$} \\
\hline
\end{tabular}

While the Energy Star share is one percent for strong Republicans, it is 2.5 percent for the middle group and increases to 7.5 percent for Democrats. The difference between strong Democrats and strong Republicans in the Energy Star share is 6.6 percent and significant at the 5 percent level.

We see quite a different picture for the LEED portfolio shares. Here, we do not observe a clear pattern from strong Republicans to strong Democrats. There are no LEED certified properties owned by strong Democrats, although the Energy Star share for this group of CEOs is 7.5 percent. Strong Democrats have a significantly lower LEED share than strong Republicans. The difference is 0.7 percent, which is significant at the one percent level. In unreported calculations, when we merge the two certifications, we find similar figures as we do for the Energy Star shares.

Overall, we observe that strong Republicans own less green properties, which is in line with the conservative perspective of Republicans. They seem to be less open to green property investments, which could be caused by 
the relatively novelty of the investment style: green property investments did not exist by the beginning of 2000s and have only become more popular after the second half of the last decade. So it is possible that conservative CEO have a wait-and-see attitude towards sustainable property. Another explanation could be that green properties are associated with the $\mathrm{CO} 2$ and global warming debate, in which the Republican party tends to take a hostile stand against environmental policies. This may have created skepticism towards green properties, even if their financial performance may be attractive.

Strong Democrats have higher green property shares than the middle group and the strong Republicans. This supports our expectations that Democrats are more open to making environmental investments than Republicans. When we separate shares by two certifications, we see that Democrats prefer Energy Star to LEED. We will investigate this issue more deeply in the remainder of the chapter.

\subsubsection{Local Controls}

To make our analysis properly robust, we also control for local characteristics in the region where REITs invest. As in Kok, McGraw, and Quigley (2011b) and Eichholtz, Kok, and Yönder (2012), we develop a local greenness measure. Local Greenness is the ratio of total square feet of green buildings to total square feet by MSA. Portfolio Weight is the weight of total square feet at each MSA to total square feet of REIT property portfolio by year.

Multiplying the two variables for each MSA and summing them up, we obtain the Green Local Share for each REIT. This way, we determine the greenness of the location that REIT invest in. We expect that in greener locations, REITs are more likely to own green buildings.

(4.3) Green Local Share ${ }_{i t}=\sum_{j=1}^{48}$ Local Greenness $_{j t}{ }^{*}$ Portfolio Weight ${ }_{i j t}$

where

$i$ stands for REIT $i, j$ stands for MSA $j$ and $t$ stands for year $t$. 
The second local control variable is related to the political preference in the location in which REITs invest. From the FEC database, we obtain whether Democrats or Republicans won a congressional district during each federal election since 2002. We create a dummy variable, Dem_District where we give one if Democrats win and zero if Republicans win.

Then, we determine congressional districts where REIT properties are located by matching counties in the SNL Financial database with congressional districts. Finally, we calculate Local_Dem, which is a weighted local political preference measure. Local_Dem gets a value between zero and one. As it increases the weighted location where REITs own properties becomes more Democratic.

(4.4) Local_Dem ${ }_{i t}=\sum_{k}$ Dem_District ${ }_{k t}{ }^{*}$ Portfolio Weight ${ }_{i k t}$

where

$i$ stands for REIT $i$, $k$ stands for congressional district $k$ and $t$ stands for year $t$.

We expect that in more Democrat-oriented locations, REITs are more likely to own green properties, since Democrats are more open to environmental issues. As the location becomes more Democratic, there might be an increase in the demand of green properties and REITs might own more green properties to meet the demand.

\subsubsection{CEO Characteristics and Financial Controls}

In our multivariate analysis, we additionally control for CEO characteristics such as CEO age and CEO tenure. We collect data for CEO characteristics from SEC 14-F filings. We expect that younger and less experienced CEOs are more open to new types of investments such as green property investments.

We obtain financial data from SNL Financial. The data set covers US REITs 
from 2004 till $2010^{19}$. We control for log(Size) measured as the logarithm of total assets; Firm $Q$ calculated as the ratio of book value of total assets plus market capitalization minus common equity to book value of total assets; Firm Age, which is number of years since IPO; and property type dummies for residential, retail, office and hotel. We expect that larger, younger firms are more likely to own green properties. Firms with higher growth opportunities could invest in green properties. Conversely, firms with lower growth opportunities could seek new types of investments such as green properties.

Table 4.2 provides descriptive statistics, and shows that 2.6 and 0.7 percent of REIT property portfolios are Energy Star and LEED certified, respectively. For the REIT having the greenest portfolio 86 percent of the portfolio are Energy Star labeled buildings. The highest LEED share is 37 percent.

The mean of Dem_Ratio is 38 percent indicating that REIT CEOs contribute more to Republicans than to Democrats. When we look at strong Democrats and Republicans, we see that 13 percent of the CEOs in the sample are strongly Republican and 6 percent of the sample is strongly Democrat.

Regarding local controls, in the locations where REITs own properties we see more Energy Star certified properties than LEED certified properties. Additionally, the locations where REITs own buildings are slightly more Democrat-oriented, since the average value of Dem_Local is 0.54 in these regions.

The average REIT CEO is around 53 years old and has been working as a director for 12 years in our sample. The number of years since the IPO is 17 for the average REIT. On average, Firm $Q$ is 1.37 .

\footnotetext{
${ }^{19}$ We do not include data before 2004 since there are very few Energy Star and LEED certified properties owned by REITs before that year.
} 


\section{Table 4.2}

\section{Descriptive Statistics}

\begin{tabular}{|c|c|c|c|c|c|}
\hline & Obs & Mean & Std. Dev. & Min & Max \\
\hline & \multicolumn{5}{|c|}{ Portfolio Greenness } \\
\hline Energy Star Share & 617 & 0.026 & 0.095 & 0 & 0.860 \\
\hline \multirow[t]{2}{*}{ LEED Share } & 617 & 0.007 & 0.029 & 0 & 0.367 \\
\hline & \multicolumn{5}{|c|}{ Political Preference } \\
\hline Dem_Ratio & 617 & 0.377 & 0.328 & 0 & 1 \\
\hline Dem_Dummy & 617 & 0.062 & 0.241 & 0 & 1 \\
\hline \multirow[t]{2}{*}{ Rep_Dummy } & 617 & 0.131 & 0.338 & 0 & 1 \\
\hline & \multicolumn{5}{|c|}{ Local Controls } \\
\hline Energy Star_Local Share & 617 & 0.178 & 0.117 & 0 & 0.714 \\
\hline LEED_Local Share & 617 & 0.034 & 0.042 & 0 & 0.204 \\
\hline \multirow[t]{2}{*}{ Dem_Local } & 617 & 0.538 & 0.169 & 0.140 & 1 \\
\hline & \multicolumn{5}{|c|}{ CEO Controls } \\
\hline CEO Age & 617 & 53.420 & 9.238 & 30 & 82 \\
\hline \multirow[t]{2}{*}{ CEO Tenure } & 617 & 11.723 & 7.810 & 0 & 42 \\
\hline & \multicolumn{5}{|c|}{ Firm Controls } \\
\hline Total Assets (in mlns) & 617 & 3,862 & 4,864 & 3,162 & 32,400 \\
\hline Firm Age & 617 & 17.094 & 11.835 & 0 & 50 \\
\hline Firm $Q$ & 617 & 1.375 & 0.375 & 0.603 & 4.645 \\
\hline
\end{tabular}

Notes: Table 4.2 shows the descriptive statistics. Energy Star (LEED) Share is the square feet of Energy Star (LEED) certified buildings to total square feet of buildings in annual REIT portfolios. Dem_Ratio is the ratio of contributions to Democrats to total contributions during federal elections by REIT CEOs. Dem_Dummy (Rep_Dummy) represents the strong Democrats (Republicans) who only contribute to Democratic (Republican) candidates during federal elections. Energy Star_Local Share (LEED_Local Share) is a weighted share of the square feet of Energy Star (LEED) certified buildings to total square feet of buildings where REIT properties are located. Local_Dem is a weighted local political preference measure where REITs own properties and gets a value between 0 and 1 as it increases; the weighted location where REITs own properties becomes more Democratic. Firm $Q$ is calculated as the ratio of book value of total assets plus market capitalization minus common equity to book value of total assets and Firm Age is the number of years since IPO. 


\subsection{Methodology and Multivariate Analysis}

To investigate the determinants of the likelihood to own green properties, we regress the portfolio shares of Energy Star and LEED labeled buildings on political preference measures and other controls.

We use a fractional logit model following Papke and Wooldridge (1996) to estimate portfolio greenness. When the dependent variable is a fraction, ordinary least squares might predict values of smaller than zero and larger than one, and cannot guarantee fractional predicted values of the dependent variable. For that reason, Papke and Wooldridge (1996) develop the fractional logit model to estimate equations with fractional dependent variables. The model we estimate is as follows:

$E\left(\right.$ Green Share $_{i t} \mid$ Controls $\left._{i t}\right)=G\left(\delta_{0}+\delta_{1}\right.$ Political Preference ${ }_{i}+\delta_{2}$ Local Controls $_{\text {it }}$ $+\delta_{3}$ CEO Controls $s_{i t}+\delta_{4}$ Financial Controls $\left.s_{i t}+\varepsilon_{i t}\right)$

where

$G($.$) is a function satisfying 0<G(z)<$ I for all $z \in R$.

We present the regressions of Energy Star share and LEED share on Dem_Ratio and other controls in Table 4.3. In the first three columns, the dependent variable is Energy Star share and in the last three columns, the dependent variable is LEED share. In all regressions, we control for year dummies and property type dummies. The standard errors are heteroscedasticity robust and clustered by firm. We present the odds ratio, which is the ratio of the probability of green share being equal to one and the probability of green share being equal to 0 , instead of the coefficients themselves.

In Column 1, we regress Energy Star share on Dem_Ratio and financial controls. We find that if Dem_Ratio goes from zero to one, that is, a REIT with a strongly Republican CEO would switch to a strongly Democrat CEO, the odds ratio of Energy Star share increases by a factor of 6.64 , and this is significant at the one percent level. 
In Column 2, we add local controls. We find that the Dem_Local and Green_Local have the expected signs while only Green_Local is significant. If Green_Local increases by one percent, the odds ratio for Energy Star share increases by a factor of 5.83. In Column 3, we add CEO age and tenure. We find that more experienced CEOs are more likely to own Energy Star certified properties.

Table 4.3

Regressions of Portfolio Greenness on Political Preference

\begin{tabular}{|c|c|c|c|c|c|c|}
\hline \multirow[t]{2}{*}{ VARIABLES } & $\begin{array}{c}(1) \\
\text { Energy Star }\end{array}$ & $\begin{array}{c}(2) \\
\text { Energy Star }\end{array}$ & $\begin{array}{c}\text { (3) } \\
\text { Energy Star }\end{array}$ & $\begin{array}{c}(4) \\
\text { LEED }\end{array}$ & $\begin{array}{c}(5) \\
\text { LEED }\end{array}$ & $\begin{array}{c}(6) \\
\text { LEED }\end{array}$ \\
\hline & \multicolumn{6}{|c|}{ Odds Ratio } \\
\hline \multirow[t]{2}{*}{ Dem_Ratio } & $6.642 * * *$ & $4.953 * * *$ & $3.875^{* *}$ & 0.776 & 0.686 & 0.556 \\
\hline & [4.653] & [2.759] & [2.405] & {$[0.558]$} & [0.527] & [0.386] \\
\hline \multirow{2}{*}{ Dem_Local } & & 1.619 & 2.068 & & 2.508 & 2.977 \\
\hline & & [1.930] & [2.476] & & [2.106] & [2.507] \\
\hline \multirow[t]{2}{*}{ Green_Local } & & $582.866 * * *$ & $343.253 * * *$ & & 0.134 & 0.141 \\
\hline & & [766.469] & [389.783] & & [0.863] & {$[0.854]$} \\
\hline \multirow[t]{2}{*}{ CEO Age } & & & 0.988 & & & 0.989 \\
\hline & & & [0.023] & & & [0.022] \\
\hline \multirow[t]{2}{*}{ CEO Tenure } & & & $0.931 *$ & & & 0.961 \\
\hline & & & [0.036] & & & {$[0.039]$} \\
\hline \multirow[t]{2}{*}{$\log ($ Size $)$} & 1.060 & $1.352 * * *$ & $1.413 * * *$ & $1.907 *$ & $1.820 *$ & $1.863 * *$ \\
\hline & {$[0.146]$} & [0.143] & [0.168] & [0.667] & [0.569] & {$[0.520]$} \\
\hline \multirow[t]{2}{*}{ Age } & 0.981 & 0.981 & 0.997 & 1.004 & 1.003 & 1.013 \\
\hline & [0.019] & [0.020] & [0.017] & {$[0.026]$} & [0.026] & {$[0.030]$} \\
\hline \multirow[t]{2}{*}{ Firm $Q$} & 0.218 & 0.132 & $0.113^{*}$ & 0.495 & 0.464 & 0.373 \\
\hline & {$[0.430]$} & [0.196] & [0.134] & [0.731] & [0.707] & [0.478] \\
\hline Constant & Y & Y & Y & Y & $Y$ & Y \\
\hline Year Dummies & $\mathrm{Y}$ & Y & Y & $\mathrm{Y}$ & $\mathrm{Y}$ & $\mathrm{Y}$ \\
\hline Property Type & Y & $\mathrm{Y}$ & $Y$ & Y & $Y$ & Y \\
\hline Observations & 617 & 617 & 617 & 617 & 617 & 617 \\
\hline BIC & -3831 & -3824 & -3814 & -3856 & -3843 & -3830 \\
\hline
\end{tabular}

Notes: Table 4.3 shows odds ratios from the fractional logit regression of Energy Star (LEED) Share, which is the square feet of Energy Star (LEED) certified buildings to total square feet of buildings in annual REIT portfolios on Dem_Ratio, which is the ratio of contributions to Democrats to total contributions during federal elections by REIT CEOs and other controls. Heteroskedasticity robust and firmclustered standard errors are in brackets. * indicates significance at the 10 percent level. ** indicates significance at the 5 percent level. $* * *$ indicates significance at the 1 percent level. 
In Column 3, the coefficient of Dem_Ratio is still significant after controlling for local determinants and CEO characteristics. Among financial controls, we find that larger firms are more likely to own Energy Star certified properties. In Column 4-6, we regress LEED share on Dem_Ratio and other controls. In none of the regressions, we find a significant coefficient for Dem_Ratio. We only find that firm size increases the likelihood of owning LEED certified properties.

In unreported results, when we merge Energy Star and LEED shares, we find that as the managers become more Democratic, they are more likely to invest in green properties. The results are similar to those in the regressions of the Energy Star share. The overall findings are in line with our expectations. Republicans tend to be relatively conservative people who may be more cautious to make new type of investments such as investments in green properties, and who are more likely to adopt a wait-and-see stance. Democrats are more likely to have environmental considerations play a role in their decision making, and are therefore more prone to invest in green properties.

But the different results for Energy Star and LEED are less intuitive, and we are not sure why we do find a relation between the CEO's political orientation and the degree to which a REIT owns Energy Star labeled buildings, but not with LEED buildings. A reason could be that Energy Star is a government-initiated certification system, which may be ideologically more attractive for Democrats, and less attractive to Republicans. LEED, on the other hand, is market-initiated, and may therefore be less politically controversial. This finding may also be related to the costs in making a building green. Previous research (Eichholtz, Kok and Quigley, in press) shows that there is no statistical relationship between a building's LEED label and its energy usage. For Energy Star, on the other hand, the relation with actual energy consumption is strong. This, combined with the previously quoted study in USA Today, may imply that it is relatively cheap to get a LEED label for a building, but that this could be more expensive for an Energy Star label, since the latter requires more investment in a building's physical infrastructure. So Energy Star may require more commitment of resources and therefore also more managerial commitment and conviction to make the required investments. This conviction is more likely to be found among Democrats than among Republicans. 


\section{Table 4.4}

\section{Regressions of Portfolio Greenness on Strong Democrats/Republicans}

\begin{tabular}{|c|c|c|c|c|c|c|}
\hline VARIABLES & $\begin{array}{c}\text { (1) } \\
\text { Energy Star }\end{array}$ & $\begin{array}{c}\text { (2) } \\
\text { Energy Star }\end{array}$ & $\begin{array}{c}\text { (3) } \\
\text { Energy Star }\end{array}$ & $\begin{array}{c}(4) \\
\text { LEED }\end{array}$ & $\begin{array}{c}(5) \\
\text { LEED }\end{array}$ & $\begin{array}{c}(6) \\
\text { LEED }\end{array}$ \\
\hline & \multicolumn{6}{|c|}{ Odds Ratio } \\
\hline Dem_Dummy & $\begin{array}{r}3.944 * * \\
{[2.364]}\end{array}$ & $\begin{array}{r}1.580 \\
{[0.852]}\end{array}$ & $\begin{array}{r}1.468 \\
{[0.538]}\end{array}$ & $\begin{array}{r}0.000 * * * \\
{[0.000]}\end{array}$ & $\begin{array}{r}0.000 * * * \\
{[0.000]}\end{array}$ & $\begin{array}{r}0.000 * * * \\
{[0.000]}\end{array}$ \\
\hline Rep_Dummy & $\begin{array}{c}0.238^{*} \\
{[0.184]}\end{array}$ & $\begin{array}{r}0.246 \\
{[0.244]}\end{array}$ & $\begin{array}{r}0.358 \\
{[0.332]}\end{array}$ & $\begin{array}{r}1.317 \\
{[0.675]}\end{array}$ & $\begin{array}{r}1.214 \\
{[0.630]}\end{array}$ & $\begin{array}{r}1.466 \\
{[0.819]}\end{array}$ \\
\hline Dem_Local & & $\begin{array}{r}5.259 \\
{[6.925]}\end{array}$ & $\begin{array}{r}5.177 \\
{[7.145]}\end{array}$ & & $\begin{array}{r}2.084 \\
{[1.502]}\end{array}$ & $\begin{array}{r}2.381 \\
{[1.844]}\end{array}$ \\
\hline Green_Local & & $\begin{array}{r}495.043 * * * \\
{[726.349]}\end{array}$ & $\begin{array}{r}232.852 * * * \\
{[300.821]}\end{array}$ & & $\begin{array}{r}0.355 \\
{[2.258]}\end{array}$ & $\begin{array}{r}0.413 \\
{[2.606]}\end{array}$ \\
\hline CEO Age & & & $\begin{array}{r}0.983 \\
{[0.026]}\end{array}$ & & & $\begin{array}{r}0.990 \\
{[0.021]}\end{array}$ \\
\hline CEO Tenure & & & $\begin{array}{c}0.926 * * \\
{[0.035]}\end{array}$ & & & $\begin{array}{r}0.944 \\
{[0.045]}\end{array}$ \\
\hline $\log ($ Size $)$ & $\begin{array}{r}1.193 \\
{[0.183]}\end{array}$ & $\begin{array}{r}1.383 * * * \\
{[0.132]}\end{array}$ & $\begin{array}{r}1.447 * * * \\
{[0.159]}\end{array}$ & $\begin{array}{r}1.883^{* *} \\
{[0.570]}\end{array}$ & $\begin{array}{r}1.783^{* *} \\
{[0.498]}\end{array}$ & $\begin{array}{r}1.834 * * \\
{[0.460]}\end{array}$ \\
\hline Age & $\begin{array}{r}0.978 \\
{[0.019]}\end{array}$ & $\begin{array}{r}0.977 \\
{[0.022]}\end{array}$ & $\begin{array}{r}0.995 \\
{[0.019]}\end{array}$ & $\begin{array}{r}1.001 \\
{[0.028]}\end{array}$ & $\begin{array}{r}1.000 \\
{[0.027]}\end{array}$ & $\begin{array}{r}1.016 \\
{[0.033]}\end{array}$ \\
\hline Firm $Q$ & $\begin{array}{r}0.334 \\
{[0.531]}\end{array}$ & $\begin{array}{r}0.209 \\
{[0.257]}\end{array}$ & $\begin{array}{c}0.158^{*} \\
{[0.153]}\end{array}$ & $\begin{array}{r}0.455 \\
{[0.684]}\end{array}$ & $\begin{array}{r}0.429 \\
{[0.646]}\end{array}$ & $\begin{array}{r}0.289 \\
{[0.350]}\end{array}$ \\
\hline Constant & $\mathrm{Y}$ & $\mathrm{Y}$ & $\mathrm{Y}$ & $Y$ & $Y$ & $\mathrm{Y}$ \\
\hline Year Dummies & Y & $Y$ & Y & $Y$ & $Y$ & Y \\
\hline Property Type & $Y$ & $\mathrm{Y}$ & $\mathrm{Y}$ & $Y$ & $Y$ & Y \\
\hline $\begin{array}{l}\text { Observations } \\
\text { BIC }\end{array}$ & $\begin{array}{r}617 \\
-3824\end{array}$ & $\begin{array}{r}617 \\
-3816\end{array}$ & $\begin{array}{r}617 \\
-3806\end{array}$ & $\begin{array}{r}617 \\
-3850\end{array}$ & $\begin{array}{r}617 \\
-3837\end{array}$ & $\begin{array}{r}617 \\
-3825\end{array}$ \\
\hline
\end{tabular}

Notes: Table 4.4 shows odds ratios from the fractional logit regression of Energy Star (LEED) Share, which is the square feet of Energy Star (LEED) certified buildings to total square feet of buildings in annual REIT portfolios on Dem_Dummy, Rep_Dummy and other controls. Dem_Dummy (Rep_Dummy) represents the strong Democrats (Republicans) who only contribute to Democratic (Republican) candidates during federal elections. Heteroskedasticity robust and firm-clustered standard errors are in brackets. * indicates significance at the 10 percent level. $* *$ indicates significance at the five percent level. *** indicates significance at the one percent level.

In Table 4.4, we regress green shares on dummies for strong Democrats and Republicans. We define a CEO as a strong Democrat (Republican) if he only contributes to Democrats (Republicans). In Column 1 of Table 4.4, we control for financial determinants. We find that REITs led by strong Democrats have higher odds of having a green property portfolio by a factor 
of 3.94 than the middle group including non-donors.REITs led by strong Republicans have lower odds by a factor of 0.24 than the middle group.

As we separately control for strong Democrats and strong Republicans, we find significant opposite signs for the coefficients for the two dummies, supporting our hypotheses related to Republicans being relatively conservative and Democrats being more prone to environmental issues. However, in Column 2 and 3, where we control for local determinants and CEO characteristics, the coefficients become insignificant although they have the expected signs. ${ }^{20}$

In Columns 4-6, we estimate the LEED share on the two dummies. Interestingly, we find that strong Democrats are significantly less likely to own LEED certified properties, although the economic impact is small. This may be explained by the same line of reasoning we employed above.

\subsection{Concluding Remarks}

In this chapter, we evaluate factors affecting green property investments among U.S. REITs. The sustainable property literature has thus far concentrated on the financial and economic performance of those properties and portfolios, but not on the motivations driving green investments in property. This chapter contributes to the literature from the owner's perspective and investigates the main determinants of green property investment decisions at the supply side.

We test whether the political preference of REIT CEOs determines green property investments by the REITs. We measure political preference by looking at the ratio of political contributions of REIT CEOs to Democrats to their contributions to both Democrats and Republicans during federal elections. We document that REIT CEOs are generally contributing more to Republicans than to Democrats.

We define the greenness of a REIT property portfolio as the ratio of square feet of Energy Star and LEED certified properties to total square feet of properties by year by REIT. During our analysis, we control for financial and local characteristics including a measure of the locational greenness of the

${ }^{20}$ The results are similar to Energy Star share regressions when we merge Energy Star and LEED shares in unreported regressions. 
properties and the political choices regarding sustainability in REIT portfolios, and we also control for other CEO characteristics.

We find that the ratio of CEO contributions to Democrats to total CEO contributions increases from zero to one, the odds ratio of the REIT owning Energy Star labeled properties goes up by a factor of 3.88-6.64. We also look at strongly Democrat and strongly Republican CEOs, who contribute only to one of those parties. We document that REITs led by strong Democrats have a higher likelihood to invest in Energy Star certified properties while those led by strong Republicans have a lower likelihood to invest compared to the middle group after controlling for financial determinants, although the effects disappear when we additionally control for local determinants and CEO characteristics.

This is in line with our expectations that Democrats are more prone to environmental issues and that Republicans generally tend to be more conservative and less open to new types of investments such as green property investments. Among other determinants, firm size and local greenness are important factors increasing the likelihood of green property investments. As the CEO is more experienced, he is less likely to invest in green properties, possibly due to an ingrained investment style and a reluctance to make changes in it.

For LEED certified buildings, our results are very different. We do not find a significant relation between a CEOs political preference and the likelihood of the REIT to own LEED labeled buildings. And when we look at strong Democrats and Republicans, we document that REITs led by strong Democrats are even significantly less likely to own LEED certified properties. There seems to be a clear preference for one type of building label over the other among the CEOs who politically most committed to the Democratic party: they prefer Energy Star certifications to LEED. We also find that the larger REITs generally prefer LEED certified buildings. 


\section{Chapter 5 \\ Portfolio Greenness and the Financial Performance of REITs $^{21}$}

\subsection{Introduction}

Investors increasingly incorporate information on the environmental, social and governance (ESG) performance of corporations into their investment decisions. The real estate sector is of specific interest from an environmental perspective, as it has been well-documented that the sector is responsible for some 40 percent of global greenhouse gas emissions, for 55 percent of the global use of wood, and for about 75 percent of the US electricity consumption. ${ }^{22}$ More efficient use of energy and other resources by the real estate sector can structurally reduce these figures, and thus lower the demand for increasingly scarce (and costly) natural resources.

Importantly, improved sustainability performance in the real estate sector may very well be aligned with enhanced financial performance, through lower operational costs as well as reduced portfolio risk. Indeed, a 2007 McKinsey report has suggested that many investments aimed at reducing carbon emissions from buildings could be made at a profit (Enkvist, Naucler, and Rosander, 2007).

The effect of energy efficiency and sustainability on financial performance in real estate markets has been investigated mainly at the individual asset level. The common question addressed in the literature is how "green" certification of properties is related to cash flows and property valuations, and generally the evidence shows positive financial effects associated with better environmental performance. For example, commercial buildings with energy efficiency ratings command significantly higher rents, higher and more stable occupancy rates, and higher prices than otherwise comparable conventional buildings (Eichholtz, Kok, and Quigley, 2010; Fuerst and McAllister, 2011). On the other hand, lower levels of energy efficiency and sustainability have been associated with an increased risk of obsolescence

\footnotetext{
${ }^{21}$ This chapter is based on Eichholtz, Piet; Nils Kok and Erkan Yönder. 2012. "Portfolio Greenness and the Financial Performance of REITs." Journal of International Money and Finance, 31(7), 1911-29.

${ }^{22}$ See, for example: RICS. 2005. "Green Value," London and Vancouver: RICS, See also: Energy Information Agency, EIA, http://www.eia.gov.
} 
(Kok and Jennen, 2011). But to improve the environmental performance of their property portfolio, building owners have to incur capital expenditures.

The existing body of empirical research on green buildings considers just benefits, and while it is enticing that green buildings command price premiums, it may take a similar investment to retrofit or enhance the building. Indeed, there is no convincing empirical evidence that shows the return on retrofits, or green investments for a building owner. Thus far, systematic cost-benefit analyses at the building level have been limited to case studies (Kats, 2003; Ciochetti and McGowan, 2009).

The operating and stock performance of property companies - Real Estate Investment Trusts (REITs) - is the eventual outcome of the interplay between the costs and benefits from investments in properties. Investigating this interplay may shed some light on the question whether investments in the greenness of buildings creates value for property investors. As the operating and stock performance of REITs is readily observable, and since it is possible to obtain building-level information about their investment portfolios, REITs provide an ideal vehicle for empirical research on the financial implications of the environmental performance of property portfolios.

The financial performance of REITs may be affected by the extent of greenlabeled properties in their portfolio through two different channels. The first channel is related to the direct benefits of green properties. These benefits include increased operating efficiency through lower operational costs (and thus lower exposure to rising energy prices), but also higher and more stable occupancy rates and higher valuations of properties. The second channel is related to the ancillary benefits of corporate social responsibility (CSR) by increasing investments in portfolio greenness. These CSR-related investments may lead to better reputation (Turban and Greening, 1997) and enhance loyalty of employees, customers and local communities (Ribstein, 2005). Consequently, a better CSR performance may improve financial performance. Our aim in this chapter is to investigate the aggregate effect of the two channels on operating and stock performance.

We match data on LEED and Energy Star certified buildings with detailed information on REIT portfolios and calculate the share of green properties for each REIT over the 2000-2011 period. In order to control for the muchdiscussed endogeneity between environmental and financial performance, 
we use two instrumental variables - locational greenness and local environmental government policies. Estimating a two-stage regression model, our findings indicate that portfolio greenness is positively related to the operating performance of REITs.

We document that if a REIT increases the weight of green properties within the portfolio by one percent, the return on assets (ROA) increases by around 3.5 percent for LEED certified properties and by about half a percent for Energy Star certified properties. We also find that if a REIT increases the share of green properties within the portfolio by one percent, the return on equity (ROE) increases by around seven percent for LEED certified properties and by about one percent for Energy Star certified properties. Our findings are robust to using alternative measures of operating performance, such as funds-from-operations (FFO) as a fraction of total revenue. Our results suggest that REITs are in the still in an early phase of incorporating elements related to energy efficiency and sustainability into their investment portfolios and have substantial opportunities to enhance operating returns by investing in green certified buildings or in commercial building retrofits.

We then address the impact of portfolio greenness on the stock performance of REITs. We find no significant relationship between greenness and abnormal returns, but we document that the greenness of REIT portfolios is negatively related to the estimated market beta. We explain the latter finding by the fact that green properties may be less exposed to energy price fluctuations and may be less prone to occupancy risks. REITs, through the property portfolio that they own, are less exposed to these influences, and are therefore less prone to fluctuations in the business cycle. On the other hand, the absence of a relation between abnormal stock performance and portfolio greenness suggests that stock prices may already reflect the higher cash flows deriving from investments in more efficient properties.

The remainder of this chapter is organized as follows: the next section summarizes the literature on corporate social responsibility, green buildings and financial performance. The third section describes our construct of portfolio greenness and the financial data on REITs. In the fourth section, we outline the model, making explicit our controls for endogeneity, and we discuss the main findings. The final section provides the conclusion and a short discussion. 


\subsection{Literature Review}

\subsubsection{Corporate Social Responsibility and Corporate Financial Performance}

Hitherto, there is no empirical research assessing the relation between investments in the energy efficiency or sustainability of commercial buildings, and the financial performance of their owners - equity REITs or other property investors. However, the real estate investment industry can make inferences from a well-developed strand of literature that studies the broader concept of CSR and its impact on the financial performance of corporations in general.

The effects of many different types of CSR on corporate financial performance have been documented extensively. It has for example been argued that a stronger commitment to CSR translates into greater loyalty of employees, customers and local communities (Ribstein, 2005), as well as improved reputation (Turban and Greening, 1997). This may eventually lead to better financial performance. For instance, Lev, Petrovis, and Radhakrishnan (2010) document that growth in charitable contributions is positively related to subsequent revenue growth. A meta-analysis of the literature, conducted by Margolis, Elfenbein, and Walsh (2007), evaluated 167 studies produced between 1972 and 2007. The authors find a small, but overall positive relationship between CSR and financial performance. Dividing the broad CSR into different categories, it is documented that charitable contributions, information about corporate misdeeds, environmental performance as well as broader assessment of CSR through observer perceptions and self-reported social performance have the strongest association with financial performance.

An important caveat of all research into the financial implications of CSR is the issue of causality. Margolis and Walsh (2003) and Orlitzky, Schmidt, and Rynes (2003) claim that firms with weak financial performance are less likely to engage in socially responsible behavior simply because less profitable companies have fewer resources to allocate towards CSR activities than highly profitable companies. Waddock and Graves (1997) refer to this concept as the slack resource theory. Contrasting, Lev, Petrovis, and Radhakrishnan (2010) do not find convincing evidence that revenue growth substantially contributes to corporate giving. 
Moderating factors also influence the relation between CSR and financial performance. The competitiveness hypothesis posits that in extremely competitive environments, companies' profit margins narrow, placing shareholder value and firm well-being at risk, thus compelling management to cut costs. In such circumstances, companies may even engage in socially "irresponsible" activities such as compromising product safety, unethical treatment of employees, or misleading customers (Campbell, 2007).

Similarly, at the other end of the spectrum, in monopolistic environments with virtually no competition, reputation and customer loyalty holds no threat to the profitability of the firm and CSR thus becomes less relevant. Indeed, according to Campbell (2007), healthy levels of competition alongside with stable profitability increase the likelihood of investing in CSR efforts in order to uphold the reputation of the firm, and to avoid losing the trust of its suppliers and customers, which would compromise firm profitability.

\subsubsection{The Greenness of REITs and Financial Performance}

The literature on corporate social responsibility in real estate companies (REITs) mainly focuses on corporate governance (Ghosh and Sirmans, 2003; Bauer, Eichholtz, and Kok, 2010a). There are a few survey-based studies on the motivations for CSR activity in the real estate market in the United States. Pivo (2008) surveys nearly 200 CEOs of REITs, real estate operating companies and property development companies. The results show that over 40 percent of the companies have invested in green buildings. The respondents consider "concern for risk and return," "opportunities to outperform," and "moral responsibility" as the strongest drivers of so-called responsible property investment. Conversely, insufficient information on the financial performance of green building and the lack of tenant demand score highest among the list of obstacles to "responsible property investment."

Two recent surveys study the environmental performance of the global universe of listed property companies and unlisted property funds at the portfolio level (Bauer et al., 2011). It is documented that the strongest environmental performers are mostly among the larger and listed property companies, with Australian firms demonstrating clear leadership. Smaller companies, especially from Asia, generally underperform when it comes to 
the integration of energy efficiency and other elements of sustainability in the property portfolio. A first analysis on the relationship between environmental performance and the operating performance of the listed property companies finds positive and significant results, although the direction of causality cannot be established.

From a theoretical perspective, the competitiveness hypothesis seems to fit the real estate market well. Real estate markets are characterized by monopolistic competition, where entities produce differentiated products, green buildings in this case, serving a competitive market with healthy levels of profit. Investments in the energy efficiency and sustainability of properties may not only lead to the ancillary benefits of CSR, such as attracting institutional investors or providing better work environments, but presumably, buildings certified for energy efficiency or sustainability consume less resources and generate lower operating costs.

According to the US Green Building Council (USGBC), LEED-certified buildings have lower operating costs and provide healthier and safer working environments for occupants. The Energy Star program claims that buildings with the Energy Star label generally consume 35 percent less energy and emit 35 percent less carbon dioxide than average uncertified buildings. In addition, the literature also shows that more efficient properties generate premiums on rents and sales prices, compared to investments in standard properties, thus providing enhanced income to their owners.

Research by Eichholtz, Kok, and Quigley (2010) assesses the rents and transaction prices of LEED and Energy-Star-certified office buildings, relative to non-certified, comparable buildings in the United States. Controlling for differences in building quality, rents are documented to be about five percent higher for LEED-certified office properties, and some three percent higher for Energy-Star-rated buildings; the reported increments for transaction prices are 11 percent and 19 percent, respectively. These findings corroborate with a rapidly growing body of comparable studies (Miller, Spivey, and Florance, 2008; Wiley, Benefield, and Johnson, 2010; Fuerst and McAllister, 2011).

In a more recent paper, Eichholtz, Kok and Quigley (in press) attempt to confront the lack of information on the costs of "green" investments. Having access to the data on energy efficiency (i.e., kBTU usage per square foot) as measured and reported in the certification process, the link between energy 
efficiency, rents and asset value is investigated. The results show that variations in energy efficiency are fully reflected into rents and asset values. Importantly, estimates of the capitalization of energy savings are not related to uncertain estimates of the costs of constructing or retrofitting buildings. The authors also find that variations in rents and asset values systematically depend on other indicia of sustainability determined in the certification process. Importantly, since the observed green premiums are larger than the value represented by direct energy cost savings, it can be concluded that both greater energy efficiency of green buildings as well as their intangible rewards (e.g., higher productivity owing to improved working environment, effect on corporate image) play a role.

Risk factors may also play an important role in the implications of environmental performance of the portfolio. Most studies at the building level show a higher and less volatile occupancy level for green buildings as compared to conventional buildings. Also, more efficient properties have a reduced exposure to energy price shocks through their lower energy consumption, decreasing the owner's market risk (which is correlated with movements in energy prices). Legislative risk is another important consideration for property owners.

Federal and local governments are increasingly targeting the built environment with mandates to reduce the resource consumption of the building stock. This may lead to risk of obsolescence for non-efficient properties, forcing property owners to spend additional capital expenditures on their portfolio. Thus, real estate companies investing in the energy efficiency and sustainability of the properties in their portfolio may benefit from a decrease in risks at the property level, in addition to lower risks occurring from the scrutiny of institutional investors regarding the corporate social responsibility of their operations.

\subsection{REITs and Green Buildings}

\subsubsection{Green Building Data}

To measure the greenness of property portfolios, we follow the existing literature on the financial performance of green buildings in the United States. Green buildings are those certified by the US Green Building Council's 
LEED program, or buildings that have received an Energy Star certificate from the Environmental Protection Agency (EPA). These two leading certification programs aim to encourage energy-efficiency and sustainability in the (re)development of properties in United States (and beyond).

The US Green Building Council (USGBC) initiated the LEED program in 1998. It provides third-party verification that a building is designed and constructed using strategies aimed at improving performance across the following dimensions: energy consumption, water use, $\mathrm{CO}_{2}$ emissions, indoor environmental quality, and stewardship of resources. The certification covers six different components of sustainability, including energy performance and material selection. ${ }^{23}$

The market adoption of the LEED label is growing rapidly, and the total number of LEED-certified commercial buildings as of August 2011 was 10,121 . There are also 31,705 commercial buildings registered in the LEED system (these are not yet LEED-certified). Nearly one third of new construction in the United States is now comprised of LEED-certified buildings, rising from just two percent in $2005 .{ }^{24}$

The Energy Star label is focused solely on energy management and consumption. Founded in 1992 by the U.S. Environment Protection Agency (EPA) and the U.S. Department of Energy (DOE), the program provides webbased tools for the assessment of energy consumption and evaluates the efficiency of buildings' energy use with respect to a base building of similar size and quality. Contrary to LEED, the Energy Star program rates buildings on their actual energy consumption; thus, it only applies to completed and fully operational properties.

The EPA started certifying residential real estate in 1995 and extended its program to office buildings in 1999. Retail space, hotels, and warehouses have been labeled since 2001, 2002, and 2005 respectively. As of August 2011, 15,146 commercial buildings had received an Energy Star label. Currently, office buildings are still the dominant property type in the Energy Star universe, representing about 38 percent of all certified buildings.

\footnotetext{
${ }^{23}$ See http://www.usgbc.org for more information.

${ }^{24}$ McGraw-Hill Construction, 2010. Green Outlook 2011: Green Trends Driving Growth.
} 
We obtain data on all properties in the portfolios of US REITs from the SNL Real Estate database. ${ }^{25}$ Using GIS software, we convert the addresses of buildings in the database into a unique combination of longitude and latitude, and then match the dataset to LEED and Energy-Star-certified buildings, using the files maintained by the USGBC and EPA, respectively. ${ }^{26}$ We also collect data on the exact scores provided by LEED and Energy Star, measuring the "greenness" of each certified property in the REIT portfolio. We extract the year of certification from the EPA and USGBC databases, and the year of acquisition and the year of sale from the SNL database. We create annual "snapshots" of the property portfolio for each REIT and identify the LEED or Energy-Star-certified properties therein, creating a dynamic dataset of the greenness of REIT portfolios. For instance, if a REIT acquired a property in 2005 , sold the property in 2008 , and the property was certified in 2006, then the property is counted as green in 2006 and 2007 only.

Figure 5.1 presents the dynamics of the greenness of portfolios of US equity REITs from January 2000 through August 2011. The figure does neither cover REITs that are delisted or acquired, nor does it include REITs that are excluded from the NAREIT index. Overall, we investigate the portfolios of 128 REITs, of which some 60 percent own green buildings.

We document that there are 708 LEED registered properties owned by REITs as of August 2011. Registered properties pass some stages of evaluation and are expected to be certified later. Of the LEED registered properties owned by REITs, around 70 percent are certified within 1.7 years. Considering these average figures, we therefore expect that REITs will own around 350 to 500 LEED certified properties by the end of 2012. In 2001, the very first LEED-registered building appeared in a REIT portfolio, but especially after 2006, we notice a substantial increase in the number of LEED-registered properties.

\footnotetext{
${ }^{25}$ SNL Real Estate combines news and data on real estate companies around the world. The universe includes over 750 companies and more than 110,000 properties in 38 different countries.

${ }^{26}$ In some cases, we revert to manual matching, e.g., when the owner of a certified building is a REIT according to the green property database but our software cannot find a perfect match in the REIT property portfolio.
} 
Figure 5.1

\section{Green Buildings in the Portfolios of US REITs}

\section{A. LEED Registered and LEED Certified Buildings}

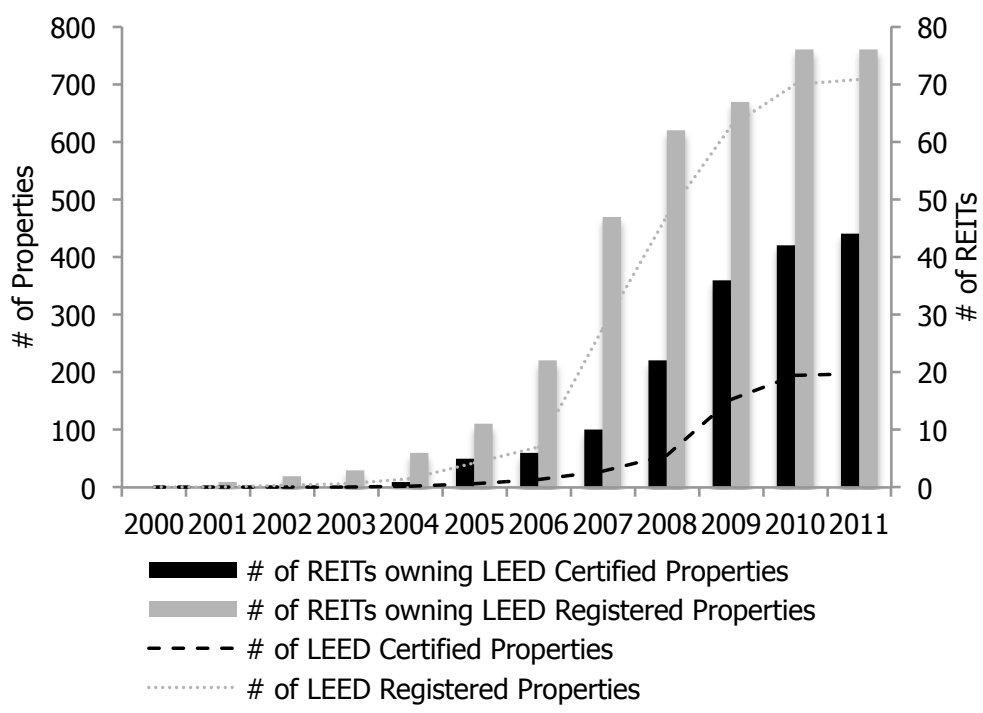

\section{B. Energy Star Certified Buildings}

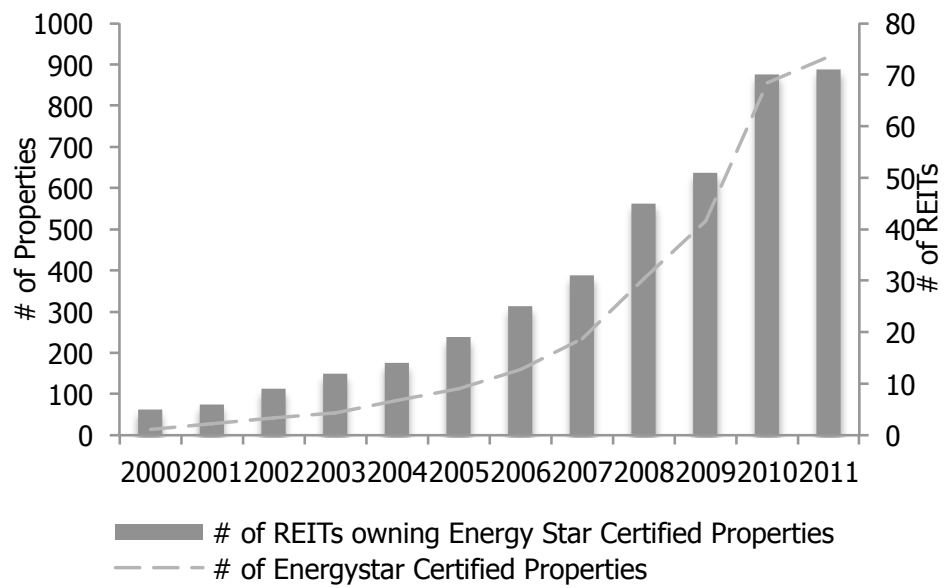

Notes: The figure shows the greenness of US REIT portfolios from 2000 to 2011. Panel A shows the properties that are LEED registered and certified and the REITs owning these properties. Panel B shows the properties that are Energy Star certified and the REITs owning these properties 
REITs have owned Energy-Star-certified properties since the beginning of the sample period (January 2000). As of August 2011, 71 REITs own an aggregate of 919 Energy Star certified properties. Similar to LEED certified properties, we observe a substantial increase in the number of Energy-Starcertified properties owned by REITs after 2006.

\subsubsection{The Greenness of REITs}

We construct two dynamic measures of portfolio greenness for each REIT. First, we count the number of properties certified as green for each year and each REIT, standardized by the total number of properties owned by the REIT in the corresponding year. Second, for each REIT we sum the square feet of all properties certified as green for each year and standardize the sum by the total square feet of the property portfolio owned by the same REIT in the corresponding year. The models are as follows:

(5.1) Buildings_Certified ${ }_{i t}^{g}=\frac{\# \text { of Certified Properties }}{\text { it }} \times 100$

(5.2) Sqft_Certified ${ }_{i t}^{g}=\frac{\sum_{/} \text {Sqft of Certified Property }}{\sum_{\text {ilt }}^{g}} \times 100$

where

$i$ stands for REIT $i, t$ stands for year $t$, / stands for property / and $g$ is the certification, which is either LEED or Energy Star. 


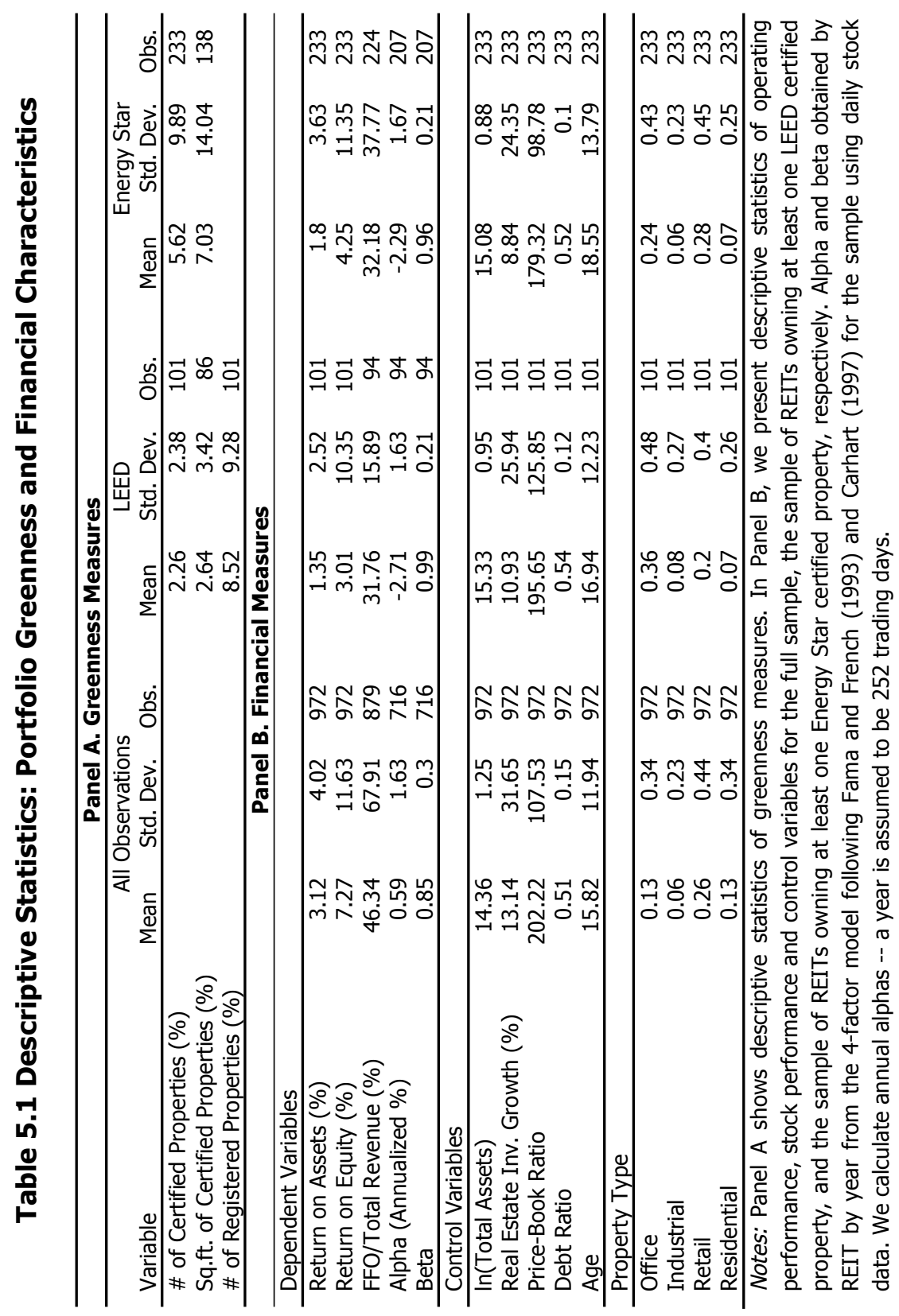


In Panel A of Table 5.1, we present the average and standard deviation for each of the greenness measures calculated by the formulas above. For the REITs owning at least one LEED certified property, the average property portfolio covers about three percent of the overall portfolio. In the greenest REIT portfolio, 14 to 17 percent are LEED certified properties, depending on the measure. Some eight percent of the REIT portfolios include LEED registered properties and 43 percent of the portfolio of the greenest REIT is LEED registered.

Energy Star certified properties are more frequently observed in the property portfolios of REITs: six to seven percent of the portfolios are Energy Star certified, on average. The "greenest" REIT has Energy Star certified properties covering 76 to 86 percent of the property portfolio, for the greenness measures calculated using the number of properties and square feet of properties, respectively.

\section{Figure 5.2}

\section{The Diffusion of Green Properties in REIT Property Portfolios}

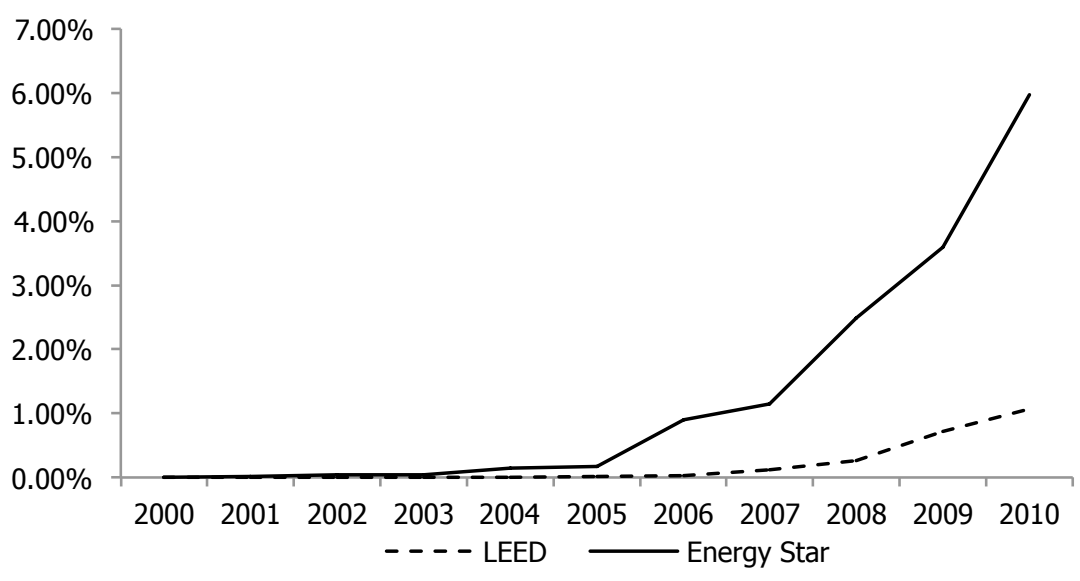

Notes: The figure presents the diffusion of LEED and Energy Star certified properties within REIT property portfolios as a ratio of green square feet over total square feet of REIT portfolios. 
Figure 5.2 shows the diffusion of green properties within REIT property portfolios during the sample period (including all REITs). The diffusion is measured by the ratio of the square feet of green properties to the total square feet of REIT property portfolios. Until 2003, certified properties were not observed in REIT property portfolios. Especially for Energy Star, there was a recent surge in certified properties in REIT portfolios. In 2010, some six percent of REIT portfolios were Energy Star certified and around one percent represented LEED certified properties. We note that these numbers are low relative to the fraction of LEED and Energy Star certified space in US commercial property markets, as recently documented by Kok, McGraw, and Quigley (2011b).

\subsubsection{Financial Data}

In addition to green data on REIT property portfolios, we gather financial data from SNL Real Estate. To avoid selection bias, the data also covers REITs that do not have any green-certified properties in their portfolio. For REITs that own green-certified properties, we collect time series data that is long enough to include the years in which the REITs did not own green certified properties, to capture any differences in the financial performance of these REITs. To analyze stock performance, we first estimate a standard 4-factor model, following Fama and French (1993) and Carhart (1997), for each REIT in the sample, using daily stock data. ${ }^{27}$ As a result, we obtain estimated abnormal returns and market betas annually for each REIT.

In Panel B of Table 5.1, we provide descriptive statistics for the REIT sample, distinguishing between the full sample and those REITs that have LEED and Energy Star certified properties in their portfolio. The mean return on assets (ROA) is 3.12 percent while the mean return on equity (ROE) is 7.27 percent. The average estimated market beta is 0.85 . For REITs owning at least one LEED-certified property, we observe that the average ROA decreases to 1.35 percent in the years when REITs own at least one LEED certified property. However, it is important to note that REITs started to own LEED-certified properties and increased the greenness of their portfolios especially in the period after 2006, which coincides with a sharp downturn in the real estate market.

\footnotetext{
${ }^{27}$ We use the NAREIT Index as a proxy for the market return and the SMB, HML and MOM factors from the Kenneth French Data Library.
} 
Table 5.1 also shows averages for some other financial variables, including the debt to asset ratio, the logarithm of total assets, the price to book ratio and the years since the IPO ("Age"). We also present the dominant property type in which each REIT invests: 26 percent of the REITs in our sample are retail REITs, while 13 percent are office REITs. Residential REITs cover 13 percent of the sample. The REITs that own LEED certified properties are mainly office and retail REITs, covering 36 percent and 20 percent of the sample, respectively. Indeed, certification programs for commercial real estate assets were first developed for commercial office and retail, followed belatedly by rating schemes for industrial property and "alternative" property types, such as self-storage and healthcare. Energy Star certified properties are predominantly owned by office and retail REITs.

\subsection{Method and Results}

\subsubsection{Endogeneity Issues}

We aim to investigate whether the greenness of a property portfolio has any effect on the financial performance of REITs. There is an ongoing debate in the CSR literature regarding the causality problem between CSR and corporate financial performance (Waddock and Graves, 1997; Orlitzky, Schmidt, and Rynes, 2003). Since well-performing companies generate higher cash flows, they might have excess cash that can be spend on CSR investments.

If we apply this to certification of properties, for REIT with a stronger past financial performance, it might be more feasible to afford the capital expenditures necessary to retrofit existing properties or to invest in greenlabeled properties. In contrast, the literature also shows that green-certified properties perform better than conventional but otherwise comparable properties, which may imply that REITs owning these green properties do better than their peers that have a portfolio of conventional properties. Thus, the direction of causality is unclear.

To control for this endogeneity problem, we apply a two-stage methodology. In the first stage, we use instrumental variables that are correlated with our construct of portfolio greenness, but that are not correlated with the residuals in the second stage. As instrumental variables, we exploit a 
measure for the greenness of the location in which a property is situated, and a measure of local green building policies for the MSA in which a property is located, following Kok, McGraw, and Quigley (2011b). We calculate "locational greenness" by dividing the total square footage of green office properties by the total square footage of all properties located in an MSA for each year, separately for LEED and Energy Star certified properties. In addition, we create a simple measure of the "intensity" of green-buildingrelated policies, aggregating LEED-related policies registered by the US Green Building Council at the city, county, and state level by MSA by year.

Presumably, when there are more green properties in the locations where REITs operate and own properties, REITs might include a larger number of green properties in their portfolio, in order to satisfy the green demand in those locations, or just to act in line with the local market norm. Similarly, if local governments support or mandate energy efficiency in properties by specific policies in the locations in which REITs operate and own properties, REITs might be affected by those policies. Indeed, government policies, such as regulation and incentives, may encourage adopting energy efficient innovations (Jaffe, Palmer, 1997), and Kok, McGraw, and Quigley (2011b) document a significant influence of green policies on the diffusion of green properties.

The locational greenness and the locational green policy might influence the greenness decision of a REIT, but the locational greenness and the locational green policy should not have an impact on the financial performance of the REIT. Locational greenness, which can be an indication of demand for green properties, or the policies implemented for encouraging green properties are not directly influencing the performance of individual real estate companies. These instruments can encourage the decision of individual companies to "go green," leading to better financial performance through increased portfolio greenness. ${ }^{28}$

To use these two variables as instruments in our analyses, we first calculate property portfolio weights by each MSA for each REIT annually, by summing the number of properties in each MSA and dividing this by the total number

\footnotetext{
${ }^{28}$ As pointed out by the referee, it may be the case that "greener" locations are higher quality locations, leading to real estate firms operating in these locations having better performance. However, our sample covers just REITs, which commonly invest in just high quality properties on high quality locations. To further address the concern, we include firm-fixed effects in additional (unreported) regressions, which should capture unobservable quality aspects of REITs and the locations they invest in. The direction of our results does not change.
} 
of properties within the 48 MSAs for each REIT. We then multiply the weights with the corresponding locational greenness measure and the locational green policy intensity measure for each MSA. We aggregate the multiplications for each year for each REIT, which results in a weighted greenness measure and a weighted green policy intensity measure for the locations where each REIT owns properties:

(5.3) $W L G_{i t}=\sum_{j=1}^{48}$ Locational Greenness $_{j t}{ }^{*}$ Portfolio Weights ${ }_{i j t}$

(5.4) $W L G P L_{i t}=\sum_{j=1}^{48}$ Locational Green Policy Intensity $_{j t}{ }^{*}$ Portfolio Weights $s_{i j t}$

where

$i$ stands for REIT $i, j$ stands for MSA $j$ and $t$ stands for year $t$. WLG is the weighted locational greenness and WLGPL is the weighted locational green policy. ${ }^{29}$

Using the portfolio greenness construct, we investigate whether the greenness of REITs has an effect on financial performance. We follow a twostage procedure: in the first stage, we regress the greenness measures on the vector of control variables used in the second stage plus the instruments created above. In the second stage, we then regress different measures of financial performance on each green measure, in addition to the vector of control variables. Adding price to book ratio and real estate investment growth as control variables offers an additional opportunity to control for causality issues. Firms with better growth opportunities or companies investing more (i.e., with higher real estate growth) may add more green properties to their portfolios. We apply the "continuously-updated" GMM estimation method of Hansen, Heaton and Yaron (1996), which is the GMM generalization of the limited-information maximum likelihood estimator for the case of possibly heteroskedastic and autocorrelated disturbances. We

\footnotetext{
${ }^{29}$ We find that there is a significant correlation with the instruments and the greenness of REITs, at the one percent significance level. Appendix Table 5.1 presents the scatterplots of the REIT greenness measures with the instruments. Panel A shows that portfolio greenness increases with weighted locational greenness. LEED portfolio shares are increasing more with locational greenness than Energy Star portfolio shares. We also observe a similar pattern with weighted locational greenness policy intensity. As we expect, if the locations in which REITs operate are greener, then REITs tend to certify more properties in their portfolios.
} 
use heteroskedasticity-robust standard errors in the second stage. The first stage and second stage models are as follows:

(5.5) Greenness it $=\partial_{0}+\partial_{1} W L G_{i t}+\partial_{2} W L G P L_{i t}+\sum_{k} \partial_{k} Z_{k i t}+\vartheta_{i t}$

(5.6) Financial Performance ${ }_{i t}=\theta_{0}+\theta_{1}$ Greenness $_{i t}+\sum_{k} \theta_{k} Z_{k i t}+\varepsilon_{i t}$

where

$i$ stands for REIT $i$, and $t$ stands for year $t$. Greenness stands for Standardized Number of Certified Properties, Standardized Square Footage of Certified Properties or Standardized Score of Certified Properties, for both LEED and Energy Star certifications. Financial Performance stands for ROA, ROE, Funds from Operations (FFO)/Total Revenue, $\alpha$ and $\beta$. $Z$ covers a vector of control variables.

Alphas and betas are obtained from the following equation, as proposed by Fama and French (1993) and Carhart (1997), using daily stock return data:

(5.7) $R_{i t}=\alpha_{i}+\beta_{i}\left(R_{m}-R_{f}\right)_{t}+\delta_{i 1} S M B_{t}+\delta_{i 2} H M L_{t}+\delta_{i 3} M O M_{t}+\epsilon_{i t}$

where

$i$ stands for REIT $i$, and $t$ stands for day $t . R_{m}$ is return on the NAREIT index, SMB, HML and MOM are Fama and French (1993) and Carhart (1997) factors.

\subsubsection{The Greenness of REIT Portfolios and Operating Performance}

In our analyses, we address both operating performance and stock performance. In all estimations for both operating performance and stock performance, we do not reject the null hypothesis of the Hansen J test that the instruments are valid instruments (no overidentification) (Hansen, 
Heaton, and Yaron, 1996) and reject the null hypothesis of the KleibergenPaap test that there is underidentification (Kleibergen and Paap, 2006). The test results are presented in the relevant regression tables.

We present the empirical results on returns on assets (ROA) in Table 5.2. ${ }^{30}$ We regress ROA on four different measures of predicted greenness. Mature REITs enjoy a significantly higher ROA. The price to book ratio, a proxy for investment opportunities, is positively related to ROA. We also control for real estate investment growth, but find significant results in none of the regressions. The control variables on property type and years are not reported here, but we do not find significant differences in ROA across property types, and as expected, returns on assets decrease significantly during the crisis period.

Importantly, in three out of four estimations, we document that the predicted greenness of REITs is significantly and positively related to return on assets. The results are stronger when we use LEED and are robust to the different measures of portfolio greenness. The results are economically significant as well: a one percent increase in the portfolio weight of LEEDcertified properties increases the ROA by around 3.5 percent annually. In other words, a one standard deviation increase in portfolio greenness, measured by square footage, will result in a 0.89 standard deviation increase in ROA. For Energy Star certified properties the effect is slightly smaller, with a one percent increase in green portfolio share associated with a 0.31 percent increase in ROA. (A one standard deviation increase in the portfolio weight of Energy Star certified properties increases ROA by 0.37 standard deviations.)

The substantial difference in the economic effects of the two certification types can be explained by the distinct effects that both measures may have on the bottom line of REITs. As documented in Eichholtz, Kok, and Quigley (in press), Energy-Star-certified properties have, on average, rents that are about two percent higher than in conventional properties. But this green premium is six percent for LEED-certified buildings. So, the greenness of properties in REIT portfolios matters beyond savings on operational expenditures alone.

\footnotetext{
${ }^{30}$ The first stage regressions are not presented here, but available from the authors upon request.
} 
Table 5.2

Regression Results: Greenness of REIT Portfolios and Operating Performance

\begin{tabular}{|c|c|c|c|c|}
\hline \multicolumn{5}{|c|}{ Panel A: Return on Assets } \\
\hline VARIABLES & $\begin{array}{l}\text { LEED } \\
(1)\end{array}$ & $\begin{array}{l}\text { LEED } \\
(2)\end{array}$ & $\begin{array}{l}\text { Energy Star } \\
\text { (3) }\end{array}$ & $\begin{array}{l}\text { Energy Star } \\
\text { (4) }\end{array}$ \\
\hline $\begin{array}{l}\text { Number of Certified Properties } \\
\text { (Predicted) }\end{array}$ & $\begin{array}{r}3.42 * * * \\
{[1.26]}\end{array}$ & & $\begin{array}{r}0.90 \\
{[0.61]}\end{array}$ & \\
\hline $\begin{array}{l}\text { Sq.ft. of Certified Properties } \\
\text { (Predicted) }\end{array}$ & & $\begin{array}{c}3.46 * \\
{[1.78]}\end{array}$ & & $\begin{array}{r}0.31^{*} \\
{[0.18]}\end{array}$ \\
\hline Total Assets & $-0.33^{* *}$ & $-0.95 * *$ & $-0.73 *$ & -0.73 \\
\hline$(\log )$ & [0.15] & {$[0.46]$} & {$[0.40]$} & [0.45] \\
\hline $\begin{array}{l}\text { Real Estate Investment Growth } \\
\text { (percent) }\end{array}$ & $\begin{array}{r}-0.01 \\
{[0.01]}\end{array}$ & $\begin{array}{r}0.01 \\
{[0.01]}\end{array}$ & $\begin{array}{r}0.00 \\
{[0.01]}\end{array}$ & $\begin{array}{r}0.01 \\
{[0.01]}\end{array}$ \\
\hline Price-Book Ratio & $\begin{array}{r}0.01 * * * \\
{[0.00]}\end{array}$ & $\begin{array}{r}0.01 * * * \\
{[0.00]}\end{array}$ & $\begin{array}{r}0.01 * * * \\
{[0.00]}\end{array}$ & $\begin{array}{r}0.01^{* *} \\
{[0.00]}\end{array}$ \\
\hline Age & $\begin{array}{r}0.06^{* * *} \\
{[0.02]}\end{array}$ & $\begin{array}{r}0.05^{* *} \\
{[0.02]}\end{array}$ & $\begin{array}{r}0.07 * * * \\
{[0.02]}\end{array}$ & $\begin{array}{r}0.06 * * * \\
{[0.01]}\end{array}$ \\
\hline Property Type Controls & $\mathrm{Y}$ & $\mathrm{Y}$ & $\mathrm{Y}$ & $\mathrm{Y}$ \\
\hline Year-Fixed Effects & $\mathrm{Y}$ & $\mathrm{Y}$ & $\mathrm{Y}$ & $\mathrm{Y}$ \\
\hline Constant & $\mathrm{Y}$ & Y & Y & $\mathrm{Y}$ \\
\hline $\begin{array}{l}\text { Observations } \\
\text { Log(Likelihood) } \\
\text { Hansen J (Prob.) } \\
\text { Kleibergen-Paap (Prob.) }\end{array}$ & $\begin{array}{r}972 \\
-2927 \\
0.36 \\
0.00 \\
\end{array}$ & $\begin{array}{r}887 \\
-2887 \\
0.75 \\
0.02 \\
\end{array}$ & $\begin{array}{r}972 \\
-3097 \\
0.82 \\
0.03 \\
\end{array}$ & $\begin{array}{r}887 \\
-2686 \\
0.89 \\
0.03 \\
\end{array}$ \\
\hline \multicolumn{5}{|c|}{ Panel B: Return on Equity } \\
\hline VARIABLES & $\begin{array}{l}\text { LEED } \\
(1) \\
\end{array}$ & $\begin{array}{l}\text { LEED } \\
(2)\end{array}$ & $\begin{array}{l}\text { Energy Star } \\
\text { (3) }\end{array}$ & $\begin{array}{c}\text { Energy Star } \\
\text { (4) }\end{array}$ \\
\hline $\begin{array}{l}\text { Number of Certified Properties } \\
\text { (Predicted) }\end{array}$ & $\begin{array}{r}7.92 * * * \\
{[2.99]}\end{array}$ & & $\begin{array}{r}2.05 \\
{[1.40]}\end{array}$ & \\
\hline $\begin{array}{l}\text { Sq.ft. of Certified Properties } \\
\text { (Predicted) }\end{array}$ & & $\begin{array}{r}7.39 * \\
{[3.83]}\end{array}$ & & $\begin{array}{r}0.66^{*} \\
{[0.35]}\end{array}$ \\
\hline Total Assets & -0.32 & -1.05 & -1.23 & -0.56 \\
\hline$(\log )$ & [0.53] & {$[0.72]$} & {$[1.02]$} & {$[0.62]$} \\
\hline $\begin{array}{l}\text { Real Estate Investment Growth } \\
\text { (percent) }\end{array}$ & $\begin{array}{r}-0.02 \\
{[0.03]}\end{array}$ & $\begin{array}{r}0.00 \\
{[0.03]}\end{array}$ & $\begin{array}{r}-0.01 \\
{[0.03]}\end{array}$ & $\begin{array}{r}0.00 \\
{[0.03]}\end{array}$ \\
\hline Price-Book Ratio & $\begin{array}{r}0.02 * * * \\
{[0.01]}\end{array}$ & $\begin{array}{r}0.03^{* * *} \\
{[0.01]}\end{array}$ & $\begin{array}{r}0.04 * * * \\
{[0.01]}\end{array}$ & $\begin{array}{r}0.03 * * * \\
{[0.01]}\end{array}$ \\
\hline Age & $\begin{array}{r}0.09^{*} \\
{[0.05]}\end{array}$ & $\begin{array}{r}0.06 \\
{[0.06]}\end{array}$ & $\begin{array}{l}0.10 * * \\
{[0.04]}\end{array}$ & $\begin{array}{r}0.08^{* *} \\
{[0.04]}\end{array}$ \\
\hline Property Type Controls & $\mathrm{Y}$ & $\mathrm{Y}$ & $\mathrm{Y}$ & $\mathrm{Y}$ \\
\hline Year-Fixed Effects & $\mathrm{Y}$ & $\mathrm{Y}$ & Y & $\mathrm{Y}$ \\
\hline Constant & $\mathrm{Y}$ & Y & Y & Y \\
\hline Observations & 972 & 887 & 972 & 887 \\
\hline Log(Likelihood) & -3869 & -3607 & -4004 & -3439 \\
\hline Hansen J (Prob.) & 0.72 & 0.91 & 0.59 & 0.81 \\
\hline Kleibergen-Paap (Prob.) & 0.00 & 0.02 & 0.03 & 0.03 \\
\hline
\end{tabular}


Notes: Table 5.2 shows the second stage results of the two-stage regressions for the REIT data ranging from 2000 to 2011. Heteroskedasticity robust standard errors are in brackets. Hansen $\mathrm{J}$ and Kleibergen-Paap test probabilities for overidentification and underindentification. $*$ indicates significance at the 10 percent level. $* *$ indicates significance at the 5 percent level. $* * *$ indicates significance at the 1 percent level.

In the ROE estimations, presented in Panel B of Table 5.2, we find that the predicted greenness variables are positively related to ROE in three out of four stratifications. The models include the same control variables as in the ROA estimations and the signs of the coefficients are in line with expectations. The estimated coefficients imply substantial economic effects from including green properties in REIT portfolios: a one percent increase in the portfolio weight of LEED-certified properties is associated with an increase in return on equity of 7.4 to 7.9 percent. If we consider standard deviation changes, a one standard deviation increase in portfolio greenness measured by square footage raises ROE by almost one standard deviation. For Energy-Star-certified properties, a one percent increase in portfolio weight increases ROE by 0.66 percent. (A one standard deviation increase in portfolio greenness raises ROE by 0.33 standard deviations.

As a robustness check, we also analyze the effects of portfolio greenness on a direct measure of cash flows, proxied by funds from operation over total revenue. ${ }^{31}$ Results are presented in Table 5.3. The financial controls generally have the expected signs. The price to market variable is positively related to FFO/Total Revenue, implying that growth opportunities are positively related to the funds from operations from the assets. Mature REITs enjoy a higher FFO ratio, which may be related to having an established property portfolio.

\footnotetext{
${ }^{31}$ As an additional robustness check, we also run regressions with a green dummy, which receives the value of one if a REIT owns at least one LEED-certified property, and zero otherwise. Compare a green REIT with a "non-green" REIT, we find significant and positive effects of greenness. In a second specification, we create a variable that counts the number of years since a REIT began to own LEED-certified properties. Excluding REITs that never owned green buildings, we find a strong positive effect of this variable on any operating performance measures and negative impact on market beta. This finding suggests that as REITs start to "go green," they are performing better.
} 
Table 5.3

\section{Regression Results: Greenness of REIT Portfolios and FFO/Total Revenue Estimations}

\begin{tabular}{|c|c|c|c|c|}
\hline VARIABLES & $\begin{array}{l}\text { LEED } \\
(1)\end{array}$ & $\begin{array}{l}\text { LEED } \\
(2)\end{array}$ & $\begin{array}{l}\text { Energy Star } \\
\text { (3) }\end{array}$ & $\begin{array}{c}\text { Energy Star } \\
\text { (4) }\end{array}$ \\
\hline $\begin{array}{l}\text { Number of Certified Properties } \\
\text { (Predicted) }\end{array}$ & $\begin{array}{r}24.87 * * * \\
{[8.68]}\end{array}$ & & $\begin{array}{r}6.79 * \\
{[4.07]}\end{array}$ & \\
\hline $\begin{array}{l}\text { Sq.ft. of Certified Properties } \\
\text { (Predicted) }\end{array}$ & & $\begin{array}{c}16.54 * \\
{[8.65]}\end{array}$ & & $\begin{array}{r}1.70 * \\
{[0.93]}\end{array}$ \\
\hline $\begin{array}{l}\text { Total Assets } \\
\text { (log) }\end{array}$ & $\begin{array}{r}2.25 \\
{[2.01]}\end{array}$ & $\begin{array}{r}2.10 \\
{[2.27]}\end{array}$ & $\begin{array}{r}-1.23 \\
{[3.45]}\end{array}$ & $\begin{array}{r}3.23 \\
{[2.09]}\end{array}$ \\
\hline $\begin{array}{l}\text { Real Estate Investment Growth } \\
\text { (percent) }\end{array}$ & $\begin{array}{r}-0.06 \\
{[0.05]}\end{array}$ & $\begin{array}{r}-0.00 \\
{[0.05]}\end{array}$ & $\begin{array}{r}0.00 \\
{[0.06]}\end{array}$ & $\begin{array}{r}-0.00 \\
{[0.05]}\end{array}$ \\
\hline Price-Book Ratio & $\begin{array}{r}0.01 \\
{[0.02]}\end{array}$ & $\begin{array}{r}0.02 \\
{[0.01]}\end{array}$ & $\begin{array}{r}0.06 * * \\
{[0.03]}\end{array}$ & $\begin{array}{r}0.02 \\
{[0.01]}\end{array}$ \\
\hline Age & $\begin{array}{r}0.10 \\
{[0.17]}\end{array}$ & $\begin{array}{r}0.01 \\
{[0.19]}\end{array}$ & $\begin{array}{r}0.14 \\
{[0.16]}\end{array}$ & $\begin{array}{r}0.05 \\
{[0.15]}\end{array}$ \\
\hline Property Type Controls & $\mathrm{Y}$ & $\mathrm{Y}$ & $Y$ & $\mathrm{Y}$ \\
\hline Year-Fixed Effects & Y & $\mathrm{Y}$ & $\mathrm{Y}$ & $\mathrm{Y}$ \\
\hline Constant & Y & $\mathrm{Y}$ & Y & $\mathrm{Y}$ \\
\hline Observations & 879 & 787 & 879 & 787 \\
\hline Log(Likelihood) & -4789 & -4301 & -4867 & -4252 \\
\hline Hansen J (Prob.) & 0.86 & 0.94 & 0.35 & 0.57 \\
\hline Kleibergen-Paap (Prob.) & 0.00 & 0.00 & 0.04 & 0.05 \\
\hline
\end{tabular}

Notes: Table 5.3 shows two-stage regression results for the REIT data ranging from 2000 to 2011. Heteroskedasticity robust standard errors are in brackets. Hansen J and Kleibergen-Paap test probabilities for overidentification and underindentification. $*$ indicates significance at the 10 percent level. ** indicates significance at the 5 percent level. ${ }^{* *}$ indicates significance at the 1 percent level.

In the ROE estimations, presented in Panel B of Table 5.2, we find that the predicted greenness variables are positively related to ROE in three out of four stratifications. The models include the same control variables as in the ROA estimations and the signs of the coefficients are in line with expectations. The estimated coefficients imply substantial economic effects from including green properties in REIT portfolios: a one percent increase in the portfolio weight of LEED-certified properties is associated with an increase in return on equity of 7.4 to 7.9 percent. If we consider standard deviation changes, a one standard deviation increase in portfolio greenness measured by square footage raises ROE by almost one standard deviation. For Energy-Star-certified properties, a one percent increase in portfolio 
weight increases ROE by 0.66 percent. (A one standard deviation increase in portfolio greenness raises ROE by 0.33 standard deviations.)

The results on the portfolio greenness measures suggest that a one percent increase in LEED-certified properties in REIT portfolios increases FFO/Total Revenue by 17 to 25 percent. Measured differently, a one standard deviation increase in portfolio greenness, measured by square footage, increases the FFO ratio by 0.33 standard deviations. The share of FFO in total revenue also increases by two to three percent if REITs increase the percentage of Energy Star certified properties.

\subsubsection{The Greenness of REIT Portfolios and Stock Performance}

We then investigate the impact of the greenness measures on stock performance and systematic risk. First, we estimate a 4-factor model, following Fama and French (1993) and Carhart (1997), using daily stock returns. We estimate this model by year for each REIT, obtaining alphas (abnormal returns) and market betas by year and by REIT. We subsequently use these estimates as dependent variables in Equation (6). Since the dependent variables are estimated coefficients from the first stage, we use a variance-weighted least squares estimation in the second stage, weighting the variance-covariance matrix with standard errors from the first stage.

Table 5.4 presents the estimation results using alpha as the measure for financial performance. The results do not show any statistically significant effect of the greenness variables as measured by LEED and Energy Star certification on the abnormal stock performance of REITs.

The statistically insignificant results for portfolio greenness may imply that the market already incorporates the greenness of REITs - this factor is thus reflected in the stock price. Certification of properties is public information and it has been widely documented that green properties may enjoy premiums. If the possibility of increased cash flows are priced in by investors there will be no "surprise effect" at earnings announcement, which may otherwise lead to abnormal returns, as documented by Derwall et al. (2005). 
Table 5.4

The Greenness of REIT Portfolios and Stock Performance

\begin{tabular}{|c|c|c|c|c|}
\hline \multicolumn{5}{|c|}{ Panel A: Alpha } \\
\hline VARIABLES & $\begin{array}{l}\text { LEED } \\
(1)\end{array}$ & $\begin{array}{c}\text { LEED } \\
(2)\end{array}$ & $\begin{array}{l}\text { Energy Star } \\
\text { (3) }\end{array}$ & $\begin{array}{l}\text { Energy Star } \\
\text { (4) }\end{array}$ \\
\hline $\begin{array}{l}\text { Number of Certified Properties } \\
\text { (Predicted) }\end{array}$ & $\begin{array}{r}0.043 \\
{[0.095]}\end{array}$ & & $\begin{array}{r}0.031 \\
{[0.028]}\end{array}$ & \\
\hline $\begin{array}{l}\text { Sq.ft. of Certified Properties } \\
\text { (Predicted) }\end{array}$ & & $\begin{array}{r}0.107 \\
{[0.144]}\end{array}$ & & $\begin{array}{r}0.007 \\
{[0.010]}\end{array}$ \\
\hline Total Assets & $-0.022 *$ & $-0.046^{*}$ & $-0.049 *$ & $-0.035 * *$ \\
\hline$(\log )$ & {$[0.012]$} & {$[0.027]$} & [0.026] & [0.017] \\
\hline Real Estate Investment Growth & 0.000 & $0.001^{* *}$ & $0.001^{*}$ & $0.001^{* *}$ \\
\hline (percent) & {$[0.000]$} & {$[0.000]$} & {$[0.000]$} & [0.001] \\
\hline Price-Book Ratio & $0.001 * * *$ & $0.001 * * *$ & $0.001 * * *$ & $0.001 * * *$ \\
\hline Age & $\begin{array}{r}{[0.000]} \\
-0.000 \\
{[0.001]}\end{array}$ & $\begin{array}{r}{[0.000]} \\
-0.001 \\
{[0.002]}\end{array}$ & $\begin{array}{r}{[0.000]} \\
-0.000 \\
{[0.001]}\end{array}$ & $\begin{array}{r}{[0.000]} \\
-0.001 \\
{[0.001]}\end{array}$ \\
\hline Property Type Controls & $\mathrm{Y}$ & $\mathrm{Y}$ & $\mathrm{Y}$ & $\mathrm{Y}$ \\
\hline Year-Fixed Effects & $\mathrm{Y}$ & $\mathrm{Y}$ & Y & Y \\
\hline Constant & Y & Y & Y & Y \\
\hline Observations & 716 & 637 & 716 & 637 \\
\hline Log(Likelihood) & -43.63 & -135.2 & -146.5 & -39.82 \\
\hline Hansen J (Prob.) & 0.13 & 0.76 & 0.69 & 0.74 \\
\hline Kleibergen-Paap (Prob.) & 0.00 & 0.08 & 0.01 & 0.02 \\
\hline \multicolumn{5}{|c|}{ Panel B: Beta } \\
\hline VARIABLES & $\begin{array}{l}\text { LEED } \\
(1) \\
\end{array}$ & $\begin{array}{c}\text { LEED } \\
(2)\end{array}$ & $\begin{array}{c}\text { Energy Star } \\
\text { (3) }\end{array}$ & $\begin{array}{l}\text { Energy Star } \\
(4)\end{array}$ \\
\hline $\begin{array}{l}\text { Number of Certified Properties } \\
\text { (Predicted) }\end{array}$ & $\begin{array}{r}-0.140 * * \\
{[0.063]}\end{array}$ & & $\begin{array}{c}-0.034^{*} \\
{[0.019]}\end{array}$ & \\
\hline $\begin{array}{l}\text { Sq.ft. of Certified Properties } \\
\text { (Predicted) }\end{array}$ & & $\begin{array}{r}-0.173 \\
{[0.111]}\end{array}$ & & $\begin{array}{r}-0.011^{* *} \\
{[0.006]}\end{array}$ \\
\hline $\begin{array}{l}\text { Total Assets } \\
\text { (log) }\end{array}$ & $\begin{array}{r}0.194 * * * \\
{[0.009]}\end{array}$ & $\begin{array}{r}0.207 * * * \\
{[0.019]}\end{array}$ & $\begin{array}{r}0.217 * * * \\
{[0.018]}\end{array}$ & $\begin{array}{r}0.189 * * * \\
{[0.009]}\end{array}$ \\
\hline $\begin{array}{l}\text { Real Estate Investment Growth } \\
\text { (percent) }\end{array}$ & $-0.001 * *$ & $-0.001 * * *$ & $-0.001 * * *$ & $\begin{array}{r}-0.001 * * * \\
{[0.000]}\end{array}$ \\
\hline \multirow[t]{2}{*}{ Debt Ratio } & $\begin{array}{r}{[0.000]} \\
-0.225^{* * *}\end{array}$ & $\begin{array}{r}{[0.000]} \\
-0.253 * * *\end{array}$ & $\begin{array}{r}{[0.000]} \\
-0.190 * *\end{array}$ & $\begin{array}{r}{[0.000]} \\
-0.257 * * *\end{array}$ \\
\hline & [0.081] & [0.079] & {$[0.084]$} & [0.062] \\
\hline \multirow[t]{2}{*}{ Price-Book Ratio } & $0.000 * * *$ & 0.000 & -0.000 & $0.000 * * *$ \\
\hline & {$[0.000]$} & {$[0.000]$} & {$[0.000]$} & {$[0.000]$} \\
\hline \multirow[t]{2}{*}{ Age } & 0.001 & 0.002 & 0.001 & 0.001 \\
\hline & {$[0.001]$} & {$[0.002]$} & {$[0.001]$} & {$[0.001]$} \\
\hline Property Type Controls & $\mathrm{Y}$ & $\mathrm{Y}$ & $\mathrm{Y}$ & $\mathrm{Y}$ \\
\hline Year-Fixed Effects & $\mathrm{Y}$ & $\mathrm{Y}$ & $\mathrm{Y}$ & Y \\
\hline Constant & Y & Y & Y & Y \\
\hline Observa & 716 & 637 & 716 & 637 \\
\hline Log(Likelihood) & 9.563 & -142.5 & -14.23 & 149.5 \\
\hline Hansen J (Prob.) & 0.85 & 0.68 & 0.39 & 0.43 \\
\hline Kleibergen-Paap (Prob.) & 0.00 & 0.07 & 0.00 & 0.02 \\
\hline
\end{tabular}


Notes: Table 5.4 shows two-stage regression results for the REIT data ranging from 2003 to 2011. Daily alphas and market betas by REIT by year obtained from the 4-factor model proposed by Fama and French (1993) and Carhart (1997). Heteroskedasticity robust standard errors are in brackets. Hansen $\mathrm{J}$ and Kleibergen-Paap test probabilities for overidentification and underindentification. * indicates significance at the 10 percent level. ** indicates significance at the 5 percent level. *** indicates significance at the 1 percent level.

In Panel B of Table 5.4, we provide estimation results of beta regressions on indicators of portfolio greenness and a vector of control variables. The statistics for the model fit are substantially higher than for the alpha estimates; the beta regressions have better explanatory power than the alpha regressions. The control variables generally have the expected signs. For instance, market risk increases with investment opportunities, as proxied by the price-to-book ratio.

In three out of four regressions, our predicted measures of portfolio greenness are negatively and significantly related to market betas. The relationship appears to have substantial economical significance. We document that the market beta of a REIT decreases by 0.14 when the portfolio weight of LEED-certified properties increases with one percent. If we consider standard deviation changes, a one standard deviation increase in portfolio greenness, as measured by number of properties, decreases the market beta by 0.55 standard deviations. The impact of Energy Star certification on beta is slightly lower: a one percent increase in the portfolio weight of Energy-Star-certified buildings reduces beta by 0.01 to 0.03 . (A one standard deviation decrease in portfolio greenness measured by number of properties decreases the market beta by 0.65 standard deviations.)

We explain these results in two ways. First, properties designated as more efficient consume less energy and other resources, so these properties are less exposed to price fluctuations of natural resources, providing a hedge against the fat-tail risk of energy price shocks. Second, the literature consistently shows that more efficient properties have higher and more stable occupancy rates than conventional, non-efficient buildings. Since the occupancy of commercial buildings is very closely related to the business cycle, this may explain the fact that REITs owning more green buildings face a lower market risk, as proxied by beta. 


\subsection{Concluding Remarks}

While there is an emerging literature that studies the financial implications of energy efficiency and sustainability on the financial performance of commercial buildings, there has been no such research into the performance of the investors that actually own these green properties. Importantly, such analysis may provide a better understanding of the net financial benefits of investments in the "greening" of properties, leading to vital new insights in the returns to investments in energy efficiency and sustainability.

This chapter investigates the impact of energy efficiency and sustainability of commercial properties on the financial performance of US REITs. We create dynamic greenness variables, using the weight of green properties in the overall REIT portfolio for both LEED and Energy Star certification. We match data on LEED and Energy Star certification with property-level data on REIT portfolios, documenting that there are more than 700 LEED-registered properties on the balance sheet of 44 REITs as of August 2011. Additionally, we observe that there are 919 Energy-Star-certified properties owned by 71 REITs as of August 2011.

We document that the number of green-certified properties in the portfolios of REITs increased strongly during the recent downturn in the real estate markets, notwithstanding severe capital and liquidity constraints. This is in line with the findings of Eichholtz, Kok, and Quigley (in press), who provide evidence that in the face of the historically severe downturn, the number of green-certified properties continued to grow exponentially, with no significant change in the financial premiums commanded by green properties. REITs seem to be persistent in pursuing the greening of their property portfolios.

The impact of greenness on corporate financial performance is addressed while controlling for the well-documented causality problem between CSR and corporate financial performance (Waddock and Graves, 1997; Margolis and Walsh, 2001, 2003; Orlitzky, Schmidt, and Rynes, 2003). Following the methodology of Kok, McGraw, and Quigley (2011b), we use two instrumental variables that may influence the greenness decision of a REIT but should not have an impact on the financial performance of the REIT: the weighted locational greenness and the weighted locational intensity of green policies. 
We apply a two-stage estimation procedure, first regressing the greenness variables on the instruments and a set of control variables. In the second stage, we then model corporate financial performance as a function of predicted portfolio greenness and the set of controls used in the first stage. Overall, our findings indicate that the greenness of REIT portfolios is positively related to operating performance. We find that if a REIT increases the share of green properties in its portfolio by one percent, its return on assets increases by around 3.5 percent for LEED-certified properties and by 0.31 percent for Energy-Star-certified properties.

Furthermore, we document that the predicted greenness variables have significantly positive effects on REITs' return on equity as well. If a REIT increases the share of green properties within the portfolio by one percent, the return on equity significantly increases by 7.39 to 7.92 percent for LEEDcertified properties and by 0.66 percent for Energy-Star-certified properties. The greenness of REIT portfolios also affects cash flows. A one percent increase in the share of LEED-certified properties in REIT portfolios raises the ratio between FFO and Total Revenue by 17 to 25 percent. The share of FFO as a fraction of total revenue increases by two to seven percent if REITs expand the share of Energy-Star-certified properties in their portfolio by one percent.

Regarding stock performance, we find that the market appears to incorporate the impact of Energy Star and LEED certification in the stock price, since there is no significant relationship between predicted greenness and abnormal returns. Importantly, we document that the predicted measures of portfolio greenness negatively affect market betas. A one percent increase in the weight of green properties within the overall REIT portfolio decreases market beta by 0.14 for LEED-certified properties and by 0.01 to 0.03 for Energy-Star-certified properties. We explain these findings by the fact that green properties are less exposed to energy price fluctuations and to occupancy risks. So, REITs and the property portfolios they own are also less exposed to these influences, and thereby better protected to the fluctuations of the business cycle.

Our results suggest that the benefits of investments in "greening" properties outweigh the costs. This has some implications for investors in US REITs. The fact that the average percentage of certified properties in REIT property portfolios is still low - about two percent for LEED and five to seven percent for Energy Star - suggests that REITs are still in the early phase of investing 
in the greenness of the properties in their portfolios, a notion that is supported by the large number of buildings that are already registered, but not yet certified by LEED. This indicates strong growth in green building certification in years to come, confirming evidence regarding the nascent greenness of REITs and other property companies, as documented in a recent survey of a large sample of property investors around the world (Rob Bauer, Piet M. Eichholtz, Nils Kok and John M. Quigley, 2011).

Given our findings that portfolio greenness is positively related to operating performance and negatively related to risk, these market developments provide a positive outlook for the return on equity and the return on assets of REIT investors, and are likely to partially shield REIT returns from the volatility of the business cycle. 
Appendix 5.1

Correlations of Portfolio Greenness of REITs with Locational Controls

A. Portfolio Greenness and Weighted Locational Greenness
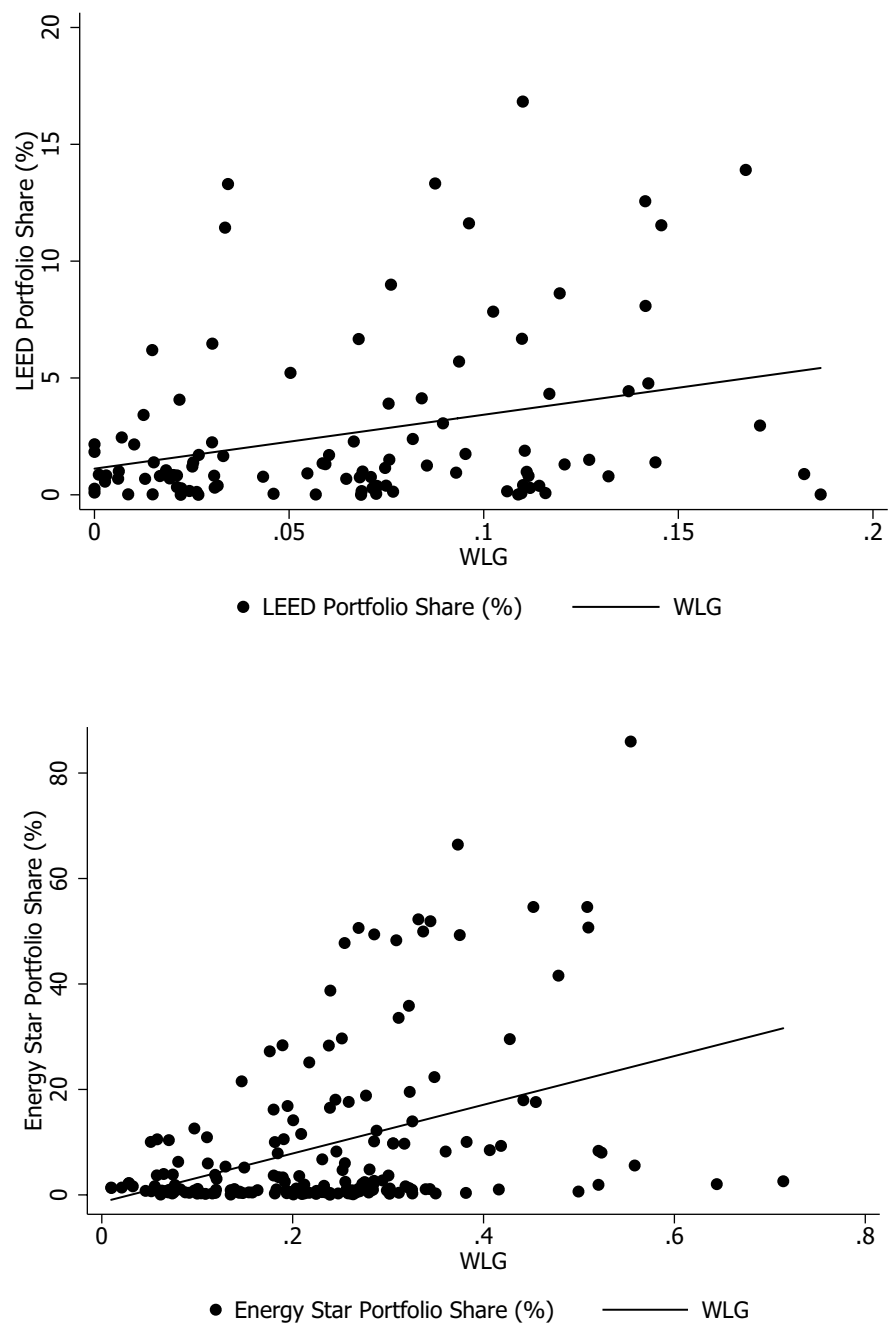
B. Portfolio Greenness and Weighted Locational Regulation

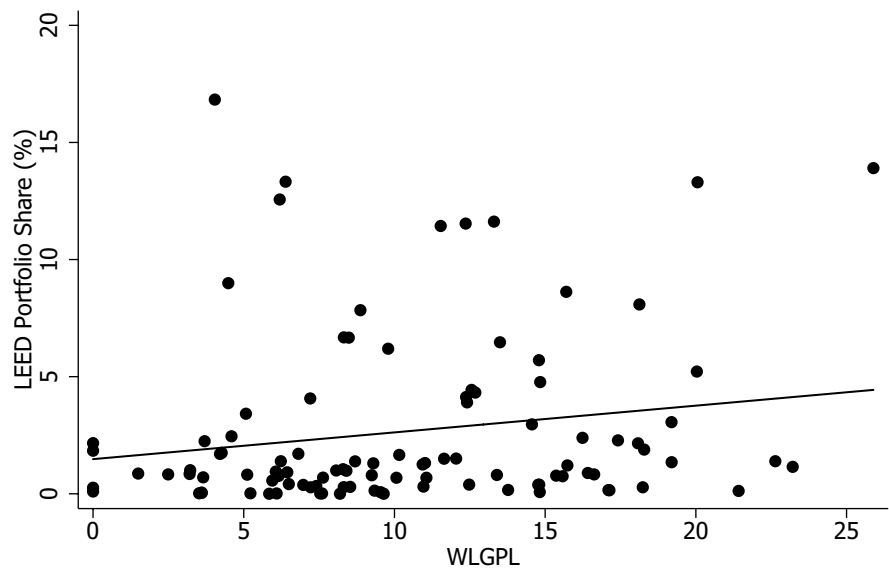

- LEED Portfolio Share (\%) — WLGPL

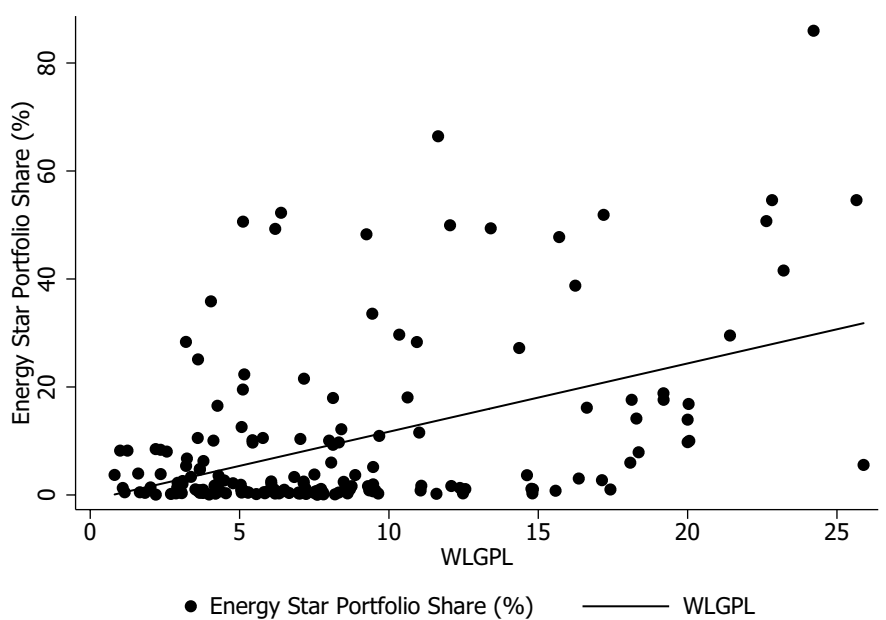

Notes: Portfolio greenness is calculated as a ratio of green square feet over total square feet of REIT portfolios. WLG stands for weighted locational greenness and WLGPL stands for weighted locational policy intensity. 


\section{Appendix 5.2}

\section{Green Properties by REIT}

\begin{tabular}{|c|c|c|c|c|c|}
\hline REIT Name & $\begin{array}{c}\text { Year of } \\
\text { First LEED } \\
\text { Certified } \\
\text { Property }\end{array}$ & $\begin{array}{l}\text { Year of First } \\
\text { Energy Star } \\
\text { Certified } \\
\text { Property }\end{array}$ & $\begin{array}{l}\text { Percentage of } \\
\text { LEED } \\
\text { Registered } \\
\text { Buildings } \\
(2010) \\
\end{array}$ & $\begin{array}{l}\text { Percentage } \\
\text { of LEED } \\
\text { Certified } \\
\text { Buildings } \\
\text { (2010) } \\
\end{array}$ & $\begin{array}{c}\text { Percentage of } \\
\text { Energy Star } \\
\text { Certified } \\
\text { Buildings } \\
(2010) \\
\end{array}$ \\
\hline $\begin{array}{l}\text { Acadia Realty } \\
\text { Trust }\end{array}$ & 2008 & 2010 & $4.11 \%$ & $1.37 \%$ & $2.74 \%$ \\
\hline $\begin{array}{l}\text { Agree Realty } \\
\text { Corporation }\end{array}$ & & 2010 & & & $3.70 \%$ \\
\hline $\begin{array}{l}\text { Alexander's, } \\
\text { Inc. }\end{array}$ & & & $20.00 \%$ & & \\
\hline $\begin{array}{l}\text { Alexandria } \\
\text { Real Estate } \\
\text { Equities, Inc. }\end{array}$ & 2007 & & $8.64 \%$ & $3.70 \%$ & \\
\hline $\begin{array}{l}\text { AMB Property } \\
\text { Corporation }\end{array}$ & & & & & \\
\hline $\begin{array}{l}\text { American } \\
\text { Assets Trust, } \\
\text { Inc. }\end{array}$ & & & & & \\
\hline $\begin{array}{l}\text { American } \\
\text { Campus } \\
\text { Communities, } \\
\text { Inc. }\end{array}$ & & & $2.86 \%$ & & \\
\hline $\begin{array}{l}\text { Apartment } \\
\text { Investment } \\
\text { and } \\
\text { Management } \\
\text { Company }\end{array}$ & & & & & \\
\hline $\begin{array}{l}\text { Ashford } \\
\text { Hospitality } \\
\text { Trust, Inc. }\end{array}$ & & 2004 & $1.00 \%$ & & $34.00 \%$ \\
\hline $\begin{array}{l}\text { Associated } \\
\text { Estates Realty } \\
\text { Corporation }\end{array}$ & & & & & \\
\hline $\begin{array}{l}\text { AvalonBay } \\
\text { Communities, } \\
\text { Inc. }\end{array}$ & 2009 & & $4.65 \%$ & $0.58 \%$ & \\
\hline $\begin{array}{l}\text { BioMed Realty } \\
\text { Trust, Inc. }\end{array}$ & 2005 & & $10.84 \%$ & $4.82 \%$ & \\
\hline $\begin{array}{l}\text { Boston } \\
\text { Properties, } \\
\text { Inc. }\end{array}$ & 2009 & 2000 & $36.81 \%$ & $8.33 \%$ & $32.64 \%$ \\
\hline $\begin{array}{l}\text { Brandywine } \\
\text { Realty Trust }\end{array}$ & 2009 & 2001 & $4.24 \%$ & $2.12 \%$ & $15.19 \%$ \\
\hline $\begin{array}{l}\text { BRE } \\
\text { Properties, } \\
\text { Inc. }\end{array}$ & 2009 & & $10.23 \%$ & $3.41 \%$ & \\
\hline $\begin{array}{l}\text { Camden } \\
\text { Property Trust }\end{array}$ & & & $0.54 \%$ & & \\
\hline $\begin{array}{l}\text { Campus Crest } \\
\text { Communities, }\end{array}$ & & & & & \\
\hline
\end{tabular}




\begin{tabular}{|c|c|c|c|c|c|}
\hline Inc. & & & & & \\
\hline CapLease, Inc. & 2005 & 2010 & $8.70 \%$ & $4.35 \%$ & $2.17 \%$ \\
\hline $\begin{array}{l}\text { CBL \& } \\
\text { Associates } \\
\text { Properties, } \\
\text { Inc. }\end{array}$ & & 2007 & $2.70 \%$ & & $4.05 \%$ \\
\hline $\begin{array}{l}\text { Cedar } \\
\text { Shopping } \\
\text { Centers, Inc. }\end{array}$ & & 2006 & & & $5.30 \%$ \\
\hline $\begin{array}{l}\text { Chatham } \\
\text { Lodging Trust }\end{array}$ & & & & & \\
\hline $\begin{array}{l}\text { Chesapeake } \\
\text { Lodging Trust }\end{array}$ & & 2010 & & & $20.00 \%$ \\
\hline $\begin{array}{l}\text { Cogdell } \\
\text { Spencer Inc. }\end{array}$ & & 2010 & & & $1.47 \%$ \\
\hline $\begin{array}{l}\text { Colonial } \\
\text { Properties } \\
\text { Trust }\end{array}$ & 2008 & 2000 & $4.46 \%$ & $1.91 \%$ & $19.11 \%$ \\
\hline $\begin{array}{l}\text { CommonWealt } \\
\text { h REIT }\end{array}$ & 2009 & 2005 & $1.17 \%$ & $0.19 \%$ & $5.63 \%$ \\
\hline $\begin{array}{l}\text { CoreSite } \\
\text { Realty } \\
\text { Corporation }\end{array}$ & & & $16.67 \%$ & & \\
\hline $\begin{array}{l}\text { Corporate } \\
\text { Office } \\
\text { Properties } \\
\text { Trust }\end{array}$ & 2005 & & $19.49 \%$ & $3.31 \%$ & \\
\hline $\begin{array}{l}\text { Cousins } \\
\text { Properties } \\
\text { Incorporated }\end{array}$ & 2009 & 2008 & $23.81 \%$ & $14.29 \%$ & $26.19 \%$ \\
\hline $\begin{array}{l}\text { DCT Industrial } \\
\text { Trust Inc. }\end{array}$ & & 2010 & & & $0.23 \%$ \\
\hline $\begin{array}{l}\text { Developers } \\
\text { Diversified } \\
\text { Realty } \\
\text { Corporation }\end{array}$ & 2008 & 2007 & $0.53 \%$ & $0.35 \%$ & $1.94 \%$ \\
\hline $\begin{array}{l}\text { DiamondRock } \\
\text { Hospitality } \\
\text { Company }\end{array}$ & & 2005 & & & $8.70 \%$ \\
\hline $\begin{array}{l}\text { Digital Realty } \\
\text { Trust, Inc. }\end{array}$ & 2007 & 2009 & $28.57 \%$ & $8.16 \%$ & $1.02 \%$ \\
\hline $\begin{array}{l}\text { Douglas } \\
\text { Emmett, Inc. }\end{array}$ & & 2006 & $3.03 \%$ & & $75.76 \%$ \\
\hline $\begin{array}{l}\text { Duke Realty } \\
\text { Corporation }\end{array}$ & 2008 & 2008 & $3.58 \%$ & $1.92 \%$ & $2.30 \%$ \\
\hline $\begin{array}{l}\text { DuPont Fabros } \\
\text { Technology, } \\
\text { Inc. }\end{array}$ & & & $62.50 \%$ & & \\
\hline $\begin{array}{l}\text { EastGroup } \\
\text { Properties, } \\
\text { Inc. }\end{array}$ & & 2000 & & & $0.41 \%$ \\
\hline $\begin{array}{l}\text { Education } \\
\text { Realty Trust, } \\
\text { Inc. }\end{array}$ & & & & & \\
\hline
\end{tabular}




\begin{tabular}{|c|c|c|c|c|c|}
\hline \multicolumn{6}{|l|}{$\begin{array}{l}\text { Entertainment } \\
\text { Properties }\end{array}$} \\
\hline Equity & & & & & \\
\hline LifeStyle & & & & & \\
\hline $\begin{array}{l}\text { Properties, } \\
\text { Inc. }\end{array}$ & & & & & \\
\hline $\begin{array}{l}\text { Equity One, } \\
\text { Inc. }\end{array}$ & & 2006 & $1.03 \%$ & & $1.03 \%$ \\
\hline $\begin{array}{l}\text { Equity } \\
\text { Residential }\end{array}$ & & & $0.22 \%$ & & \\
\hline $\begin{array}{l}\text { Essex Property } \\
\text { Trust, Inc. }\end{array}$ & & & & & \\
\hline $\begin{array}{l}\text { Excel Trust, } \\
\text { Inc. }\end{array}$ & & & $4.76 \%$ & & \\
\hline $\begin{array}{l}\text { Extra Space } \\
\text { Storage Inc. }\end{array}$ & & & & & \\
\hline $\begin{array}{l}\text { Federal Realty } \\
\text { Investment } \\
\text { Trust }\end{array}$ & 2008 & 2006 & $3.23 \%$ & $1.08 \%$ & $2.15 \%$ \\
\hline $\begin{array}{l}\text { FelCor } \\
\text { Lodging Trust } \\
\text { Incorporated }\end{array}$ & & & & & \\
\hline $\begin{array}{l}\text { First Industrial } \\
\text { Realty Trust, } \\
\text { Inc. }\end{array}$ & 2009 & 2010 & $1.03 \%$ & $0.39 \%$ & $0.13 \%$ \\
\hline $\begin{array}{l}\text { First Potomac } \\
\text { Realty Trust }\end{array}$ & 2009 & & $8.43 \%$ & $4.82 \%$ & \\
\hline $\begin{array}{l}\text { Franklin Street } \\
\text { Properties } \\
\text { Corporation }\end{array}$ & 2007 & 2006 & $38.89 \%$ & $13.89 \%$ & $30.56 \%$ \\
\hline $\begin{array}{l}\text { General } \\
\text { Growth } \\
\text { Properties, } \\
\text { Inc. }\end{array}$ & 2006 & 2008 & $6.72 \%$ & $2.10 \%$ & $7.56 \%$ \\
\hline $\begin{array}{l}\text { Getty Realty } \\
\text { Corp. }\end{array}$ & & & & & \\
\hline $\begin{array}{l}\text { Gladstone } \\
\text { Commercial } \\
\text { Corporation }\end{array}$ & & & $4.62 \%$ & & \\
\hline $\begin{array}{l}\text { Glimcher } \\
\text { Realty Trust }\end{array}$ & & 2009 & $3.70 \%$ & & $3.70 \%$ \\
\hline $\begin{array}{l}\text { Government } \\
\text { Properties } \\
\text { Income Trust }\end{array}$ & 2010 & 2009 & $5.45 \%$ & $1.82 \%$ & $43.64 \%$ \\
\hline HCP, Inc. & & 2009 & $0.74 \%$ & & $1.93 \%$ \\
\hline $\begin{array}{l}\text { Health Care } \\
\text { REIT, Inc. }\end{array}$ & & 2010 & $0.45 \%$ & & $0.45 \%$ \\
\hline $\begin{array}{l}\text { Healthcare } \\
\text { Realty Trust } \\
\text { Incorporated }\end{array}$ & & & $0.48 \%$ & & \\
\hline $\begin{array}{l}\text { Hersha } \\
\text { Hospitality } \\
\text { Trust }\end{array}$ & & 2007 & $0.00 \%$ & & $1.30 \%$ \\
\hline Highwoods & 2009 & 2007 & $2.73 \%$ & $0.30 \%$ & $17.58 \%$ \\
\hline
\end{tabular}




\begin{tabular}{|c|c|c|c|c|c|}
\hline \multicolumn{6}{|l|}{$\begin{array}{l}\text { Properties, } \\
\text { Inc. }\end{array}$} \\
\hline $\begin{array}{l}\text { HMG/Courtlan } \\
\text { d Properties, } \\
\text { Inc. }\end{array}$ & & & $0.00 \%$ & & \\
\hline $\begin{array}{l}\text { Home } \\
\text { Properties, } \\
\text { Inc. }\end{array}$ & & & $2.59 \%$ & & \\
\hline $\begin{array}{l}\text { Hospitality } \\
\text { Properties }\end{array}$ & & 2004 & $0.42 \%$ & & $16.88 \%$ \\
\hline $\begin{array}{l}\text { Host Hotels \& } \\
\text { Resorts, Inc. }\end{array}$ & & 2003 & $8.00 \%$ & & $15.20 \%$ \\
\hline $\begin{array}{l}\text { Hudson Pacific } \\
\text { Properties, } \\
\text { Inc. }\end{array}$ & 2010 & 2010 & $15.38 \%$ & $7.69 \%$ & $7.69 \%$ \\
\hline $\begin{array}{l}\text { Inland Real } \\
\text { Estate } \\
\text { Corporation }\end{array}$ & 2008 & 2010 & $2.11 \%$ & $0.70 \%$ & $0.70 \%$ \\
\hline $\begin{array}{l}\text { InnSuites } \\
\text { Hospitality } \\
\text { Trust }\end{array}$ & & & $0.00 \%$ & & \\
\hline $\begin{array}{l}\text { Investors Real } \\
\text { Estate Trust }\end{array}$ & & 2008 & $0.40 \%$ & & $1.59 \%$ \\
\hline $\begin{array}{l}\text { Kilroy Realty } \\
\text { Corporation }\end{array}$ & 2008 & 2009 & $10.00 \%$ & $5.00 \%$ & $7.86 \%$ \\
\hline $\begin{array}{l}\text { Kimco Realty } \\
\text { Corporation }\end{array}$ & & & & & \\
\hline $\begin{array}{l}\text { Kite Realty } \\
\text { Group Trust }\end{array}$ & & 2008 & $0.00 \%$ & & $5.26 \%$ \\
\hline $\begin{array}{l}\text { LaSalle Hotel } \\
\text { Properties }\end{array}$ & & 2007 & $2.86 \%$ & & $5.71 \%$ \\
\hline $\begin{array}{l}\text { Lexington } \\
\text { Realty Trust }\end{array}$ & 2009 & 2006 & $3.28 \%$ & $0.82 \%$ & $2.05 \%$ \\
\hline $\begin{array}{l}\text { Liberty } \\
\text { Property Trust }\end{array}$ & 2004 & 2007 & $8.71 \%$ & $4.49 \%$ & $8.98 \%$ \\
\hline $\begin{array}{l}\text { LTC } \\
\text { Properties, } \\
\text { Inc. }\end{array}$ & & & $0.00 \%$ & & \\
\hline $\begin{array}{l}\text { Macerich } \\
\text { Company }\end{array}$ & & 2009 & $7.06 \%$ & & $7.06 \%$ \\
\hline $\begin{array}{l}\text { Mack-Cali } \\
\text { Realty } \\
\text { Corporation }\end{array}$ & & 2000 & $0.36 \%$ & & $9.49 \%$ \\
\hline $\begin{array}{l}\text { Medical } \\
\text { Properties } \\
\text { Trust, Inc. }\end{array}$ & & & $0.00 \%$ & & \\
\hline $\begin{array}{l}\text { MHI } \\
\text { Hospitality } \\
\text { Corporation }\end{array}$ & & & $0.00 \%$ & & \\
\hline $\begin{array}{l}\text { Mid-America } \\
\text { Apartment } \\
\text { Communities, } \\
\text { Inc. }\end{array}$ & & & $0.00 \%$ & & \\
\hline $\begin{array}{l}\text { Mission West } \\
\text { Properties, }\end{array}$ & 2010 & & $1.80 \%$ & $0.90 \%$ & \\
\hline
\end{tabular}




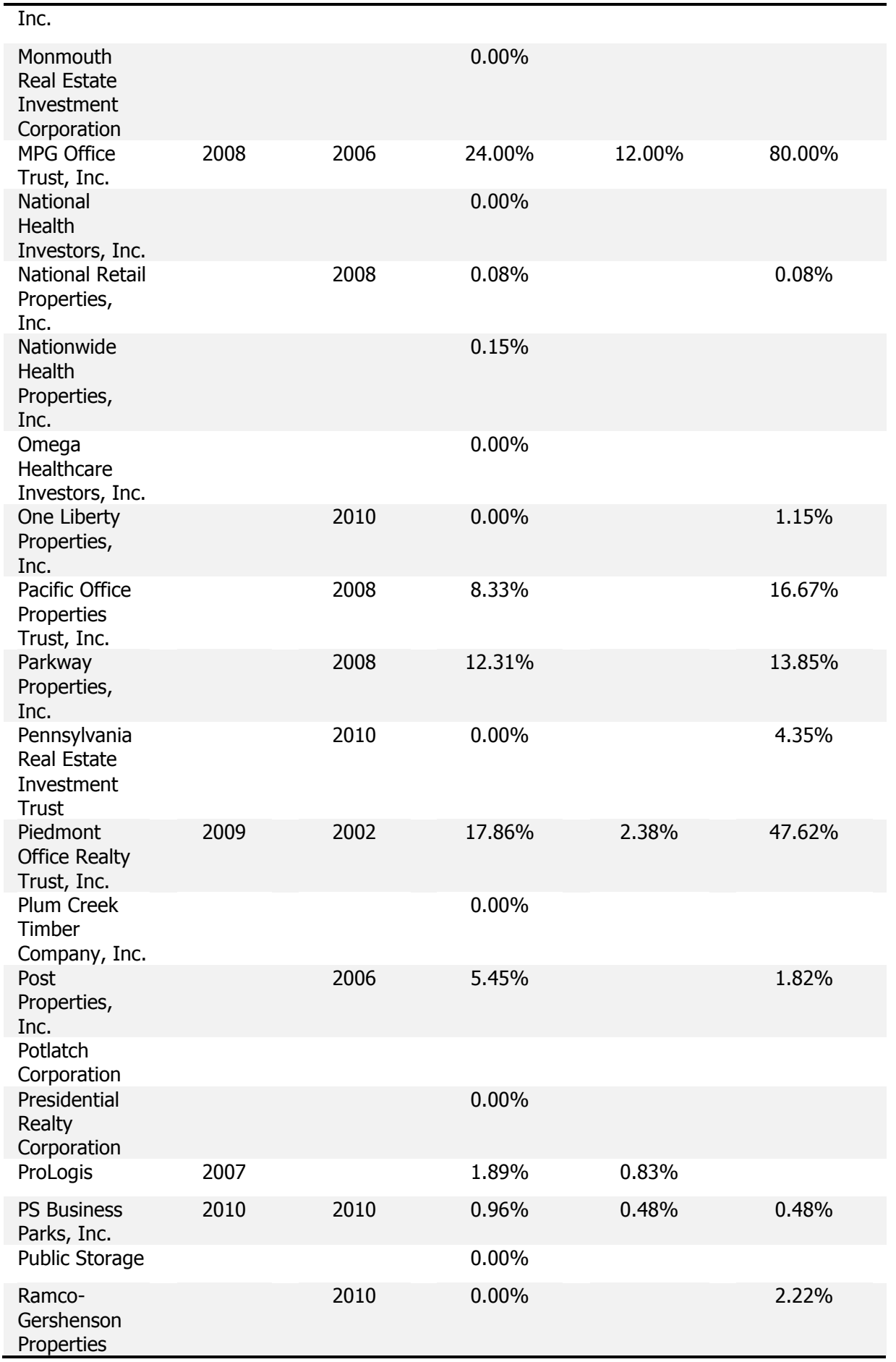




\begin{tabular}{|c|c|c|c|c|c|}
\hline \multicolumn{6}{|l|}{ Trust } \\
\hline \multicolumn{6}{|l|}{ Rayonier Inc. } \\
\hline $\begin{array}{l}\text { Realty Income } \\
\text { Corporation }\end{array}$ & & & $0.00 \%$ & & \\
\hline $\begin{array}{l}\text { Regency } \\
\text { Centers } \\
\text { Corporation }\end{array}$ & 2009 & 2003 & $5.81 \%$ & $1.01 \%$ & $2.02 \%$ \\
\hline $\begin{array}{l}\text { Roberts Realty } \\
\text { Investors, Inc. }\end{array}$ & & & $0.00 \%$ & & \\
\hline $\begin{array}{l}\text { Sabra Health } \\
\text { Care REIT, } \\
\text { Inc. }\end{array}$ & & & $0.00 \%$ & & \\
\hline $\begin{array}{l}\text { Saul Centers, } \\
\text { Inc. }\end{array}$ & 2008 & 2010 & $5.56 \%$ & $1.85 \%$ & $3.70 \%$ \\
\hline $\begin{array}{l}\text { Senior } \\
\text { Housing } \\
\text { Properties } \\
\text { Trust }\end{array}$ & & 2010 & $0.63 \%$ & & $0.31 \%$ \\
\hline $\begin{array}{l}\text { Simon } \\
\text { Property } \\
\text { Group, Inc. }\end{array}$ & 2008 & 2008 & $3.05 \%$ & $0.76 \%$ & $3.82 \%$ \\
\hline $\begin{array}{l}\text { SL Green } \\
\text { Realty Corp. }\end{array}$ & 2008 & 2008 & $31.94 \%$ & $4.17 \%$ & $12.50 \%$ \\
\hline $\begin{array}{l}\text { Sovran Self } \\
\text { Storage, Inc. }\end{array}$ & & & $0.00 \%$ & & \\
\hline $\begin{array}{l}\text { Strategic } \\
\text { Hotels \& } \\
\text { Resorts, Inc. }\end{array}$ & & 2008 & $7.14 \%$ & & $7.14 \%$ \\
\hline $\begin{array}{l}\text { Sun } \\
\text { Communities, } \\
\text { Inc. }\end{array}$ & & & $0.00 \%$ & & \\
\hline $\begin{array}{l}\text { Sunstone } \\
\text { Hotel } \\
\text { Investors, Inc. }\end{array}$ & & 2005 & $0.00 \%$ & & $11.76 \%$ \\
\hline $\begin{array}{l}\text { Supertel } \\
\text { Hospitality, } \\
\text { Inc. }\end{array}$ & & & $0.00 \%$ & & \\
\hline $\begin{array}{l}\text { Tanger } \\
\text { Factory Outlet } \\
\text { Centers, Inc. }\end{array}$ & 2010 & & $6.06 \%$ & $3.03 \%$ & \\
\hline $\begin{array}{l}\text { Taubman } \\
\text { Centers, Inc. }\end{array}$ & & & $30.43 \%$ & & \\
\hline $\begin{array}{l}\text { Terreno Realty } \\
\text { Corporation }\end{array}$ & & & $0.00 \%$ & & \\
\hline UDR, Inc. & & & $0.00 \%$ & & \\
\hline $\begin{array}{l}\text { UMH } \\
\text { Properties, } \\
\text { Inc. }\end{array}$ & 2010 & & $42.86 \%$ & $5.71 \%$ & \\
\hline $\begin{array}{l}\text { Universal } \\
\text { Health Realty } \\
\text { Income Trust }\end{array}$ & & & $0.00 \%$ & & \\
\hline $\begin{array}{l}\text { Urstadt Biddle } \\
\text { Properties Inc. }\end{array}$ & & & $0.00 \%$ & & \\
\hline U-Store-It & & 2009 & $0.00 \%$ & & $0.55 \%$ \\
\hline
\end{tabular}


CHAPTER 5

\begin{tabular}{|c|c|c|c|c|c|}
\hline Trust & & & & & \\
\hline Ventas, Inc. & & 2010 & $0.17 \%$ & & $0.66 \%$ \\
\hline $\begin{array}{l}\text { Vornado } \\
\text { Realty Trust }\end{array}$ & 2005 & 2004 & $20.08 \%$ & $3.28 \%$ & $11.48 \%$ \\
\hline $\begin{array}{l}\text { Washington } \\
\text { Real Estate } \\
\text { Investment } \\
\text { Trust }\end{array}$ & & 2008 & $7.06 \%$ & & $12.94 \%$ \\
\hline $\begin{array}{l}\text { Weingarten } \\
\text { Realty } \\
\text { Investors }\end{array}$ & & 2002 & $0.26 \%$ & & $3.13 \%$ \\
\hline $\begin{array}{l}\text { Weyerhaeuser } \\
\text { Company }\end{array}$ & & & & & \\
\hline $\begin{array}{l}\text { Whitestone } \\
\text { REIT }\end{array}$ & & 2005 & $0.00 \%$ & & $2.63 \%$ \\
\hline $\begin{array}{l}\text { Winthrop } \\
\text { Realty Trust }\end{array}$ & & 2008 & 0 & & $4.65 \%$ \\
\hline
\end{tabular}




\section{Chapter 6}

\section{Concluding Remarks, Implications for Practitioners, and Future Research}

\subsection{Concluding Remarks and Practical Implications}

REIT equities have become important assets in pension fund portfolios as a type of indirect property investment. Andonov, Eichholtz, and Kok (2013) show that investments in REITs by the global pension funds in their sample have a value of 90 billion US dollars in 2007. Currently, 35 countries have a REIT system and the global total market capitalization of REITs is 1,189 billion US dollars as of July 2011. The recent crisis has shown the resilience of the REIT market. The market lost more than half of its value in 20072008, but then rebounded. REITs have become important vehicles for property investment, due to their transparency as public property companies.

REITs are tax-exempted at the corporate level and in order to maintain their status, they have to obey certain rules that are different from regular corporations. They have to distribute 90 percent of their income to shareholders, which diminishes the discretionary cash that managers can use and lowers the likelihood of managerial entrenchment. The largest five shareholders cannot hold more than 50 percent of the outstanding shares and there must be at least 100 shareholders. This diversified ownership structure diminishes the need for external governance, since the rule diminishes the influence of stronger and influential shareholders. On the other hand, there hostile takeovers are very rare in REITs (Eichholtz and Kok, 2008), which reduces the effect of external monitoring mechanisms, making internal governance more of an issue.

In Chapter 2, I benefit from the existence of these rules and investigate the importance of corporate governance before and during the recent crisis. I find that governance quality has no impact on abnormal stock returns before the crisis, indicating that the strong legal setting for REITs diminishes the need for corporate governance during the investment frenzy.

On the other hand, I test and find that governance quality matters during the crisis. I also find that governance quality related to board structure and auditing, which are internal governance measures, is positively related to 
abnormal returns. Governance quality related to takeovers, which is an external governance measure, have no impact on abnormal returns. Additionally, institutional ownership and insider ownership have a concave relationship with abnormal returns. Over a certain threshold, insider ownership negatively affects abnormal returns.

I see different practical implications relating to different market circumstances External governance seems less relevant for REITs during the real estate boom and investors ignore external and internal governance quality when they price REIT stocks in exuberant circumstances. So spending company resources on governance quality in these times may be important in principle, but it does not seem to be valued by investors. However, during the crisis, internal governance is more of an issue because expected returns of managers decline during bad times and managers can be more prone to become entrenched.

The income and asset rules restrict REITs to real estate investment. REITs have to generate 75 percent of their income from real estate and real estate related assets. These rules mainly impact the investment decisions and limit REITs mainly to purchase, operate and sell properties. As a result, I know exactly when REITs make investments and dispositions, and how big these are. It is very difficult to have such detailed information for regular corporations, which implies that REITs can be used to study research questions that are not possible to answer by looking at regular corporations. The remainder of this dissertation is based on the detailed information REITs offer due to these income and asset rules.

In Chapter 3, I investigate the impact of managerial overconfidence on the investments of the REITs they lead and on the financial performance of these REITs. If a CEO is persistently a net buyer of his own company stocks and a long holder of in-the-money stock options (holding an in-the-money stock option until the expiry year at least twice), I define that CEO as overconfident. I subsequently find that REITs managed by overconfident managers invest more than their non-overconfident counterparts if they have enough discretionary cash. I find that the REITs with overconfident managers purchase more and sell less if they have enough discretionary cash. I also document that overconfident managers underperform their counterparts, which implies that my overconfidence proxies are not related to valuable inside information. 
In Chapter 2, I show that legal rules make internal governance more important. In Chapter 3, I find that managerial overconfidence matters and that overconfident managers increase their property portfolio size showing empire building behavior. Combining the findings of these two chapters, the main practical implication I suggest is that a governance mechanism for corporate managers is needed in order to monitor overconfident managers since my findings indicate that overconfident REIT CEOs make suboptimal investment decisions. Independent board members can play a crucial role here and mitigate the influence of managerial overconfidence on corporate investment decisions.

Chapter 4 and 5 are about corporate sustainability investments. In Chapter 4, I investigate the factors that determine the choice of owning "green" certified properties, and look specifically at the political preferences of corporate managers. I match data on LEED and Energy Star certified buildings with the buildings in REIT portfolios. Then, I calculate the ratio of the total square feet of certified buildings to the total square feet of the complete property portfolio for each REIT and for every year. I use this ratio as my measure of portfolio greenness. Collecting data on contributions to Democrats and Republicans during federal elections by REIT CEOs, I find that the ratio of CEO contributions to Democrats to total CEO contributions during federal elections has a positive impact on the likelihood of a REIT owning green properties.

I separately look at strong Democrat (Republican) leaning CEOs, who only contribute to Democrats (Republicans). I document that strongly Democrat CEOs are more likely to own green properties, while strong Republican CEOs are less likely to invest in green properties. I also find different results for LEED and Energy Star certified buildings: the difference in political preferences are reflected in the prevalence of Energy Star buildings, not in LEED buildings.

In Chapter 5, I investigate whether REITs investing in green properties enjoy better financial performance. Controlling for endogeneity by using two appropriate instruments, I find that portfolio greenness has a positive effect on operating performance. I also find that higher portfolio greenness leads to lower market beta. However, I do not find any significant impact on abnormal returns, which indicates that investors already incorporate the benefits of investing in green properties into share prices. 
My results are the first to give insight into the net financial benefits of green properties for investors. The existing research on the financial performance of green buildings has mainly been at the building level, and has not compared the costs and benefits of investing in green buildings. However, the operating performance of REITs is the net result of costs and benefits.

I have three main practical implications following Chapter 4 and 5. First, my findings show that REITs enjoy lower market betas with green property investments. One suggestion for REIT managers who are not interested in green property investments perse is that they can enjoy a lower-risk portfolio without scarifying any returns by investing in more sustainable properties. This allows them to cater to two specific investor groups at the same time. Similarly, by allocating more to "green" REITs rather than "nongreen" REITs within their portfolio, pension funds not only show social responsibility in their investments but also decrease the risk of their portfolio with a similar level of return.

Second, in Chapter 4, I explain that Republican CEOs as being conservative are more cautious to new type of investments and my findings indeed show that they invest less in green properties. There is still debate among real estate investors on the "net" economic benefits of green properties and the literature so far does not fully incorporate costs of investing in green properties show limited evidence on the net economic benefits. In Chapter 5, I document that green property investments are associated with better operating performance, which is net of the costs. My results suggest that Republican managers should reconsider their choices and feel more comfortable to invest in green properties since green property investments contribute to performance and lower the risks of portfolio; these investments are simply good for the bottom line.

Third, I find that Democrat-leaning CEOs who are more prone to sustainable investments prefer to invest in Energy Star certified buildings, whereas I do not find an effect of political preference on the appetite for LEED certified buildings. This finding adds to the debate over the comparison of Energy Star and LEED and suggest that certain REIT managers see Energy Star as more controversial than LEED. Or it could imply that LEED has been more successful in reaching out to real estate professionals of different political persuasions. Given the fact that Energy Star labeled buildings perform well economically (Eichholtz, Kok and Quigley, 2013), Energy Star should be able 
to persuade Republican-leaning REIT managers of the befits of using that label.

\subsection{Implications for Future Research}

The increasing trend in the allocation to REITs within pension fund portfolios and the recent global crisis show how indirect real estate and REITs are important for investors. In the 1990s and the 2000s, many Asian and European countries introduced a REIT system. All these developments show that we need a better understanding of the REIT structure and indirect real estate markets. Additionally, the unique legal setting surrounding REITs make them very important for research.

In Chapter 2, I show that internal governance is more relevant for REITs. In Chapter 3, my findings indicate that behavioral biases of corporate managers such as overconfidence can influence corporate investment activity. A logical research extension is to investigate whether internal governance mechanisms can diminish the impact of managerial overconfidence on corporate investment activity, and to explore what that would mean for performance. A hypothesis tested can be that better governed REITs should be less affected by managerial overconfidence. The impact of the interaction of governance quality and overconfidence on corporate investment activity should be negative as better governance is expected to decrease the overinvestment of overconfident managers.

Chapter 3 shows the importance and impact of behavioral biases of managers such as managerial overconfidence at the corporate level. On the other hand, while there is evidence on the impact of loss aversion for residential and commercial real estate markets, we do not know how overconfidence impacts individual real estate transactions. This is due to the difficulty to determine whether property buyers and sellers are overconfident or not. In subsequent research, the effect of overconfidence on individual transactions could be evaluated at the property level when a REIT is a buyer or seller since we are able to determine whether REIT managers are overconfident using corporate level data. Data from Real Capital Analytics (RCA) contain information on the transactions of properties purchased and sold by U.S. REITs, covering transaction prices, geographic location and information on hedonics. A possible hypothesis to test is that overconfident 
people overestimate the expected returns from their investment decisions so they are prone to pay more when they purchase, possibly pushing up the market prices.

In studying REITs' green property investments in Chapter 5, I use instruments to control for causality, but I apply a static model. Another straightforward approach to overcome the causality issue can be to look at differences in order to investigate the relationship between green property investment and financial performance. Differences in green property investments show green property additions to a REIT's property portfolio, and it is possible to study subsequent performance effects.

Other ways to expand our knowledge of the effects of green investment practices in listed property companies is to look at alternative proxies for greenness, such as data from the GRESB survey (see GRESB, 2012).

Using the political contributions data that I discussed in Chapter 4, research can be performed on REIT property investments after political contributions have been made. Depending on whether the candidates to whom REIT managers contributed won the election, and depending on where REIT managers make political contributions and invest in properties, one can test whether REIT managers benefit from their political networks. REITs offer an interesting laboratory environment, since it is possible to observe the exact date of investments - date of property acquisition - and the date at which a manager makes a political contribution. Moreover, it is possible to relate the location of the investments precisely to the location represented by the political office holder. This is another example of how the transparency of REITs can help research in areas that are not just specifically relevant to the real estate industry, but to the financial sector as a whole. This dissertation contains four studies aiming to do just that. 


\section{References}

Allen, P.R. and C. F. Sirmans. 1987. "An Analysis of Gains to Acquiring Firm's Shareholders: The Special Case of Reits." Journal of Financial Economics, 18(1), 175-84.

Ambrose, B.W. and P. Linneman. 2001. "Reit Organizational Structure and Operating Characteristics." Journal of Real Estate Research, 21(3), 141-62.

Andonov, Alexander; Piet Eichholtz and Nils Kok. 2013. "Value Added from Money Managers in Private Markets? An Examination of Pension Fund Investments in Real Estate," Working Paper.

Barber, Brad M.; Yi-Tsung Lee; Yu-Jane Liu and Terrance Odean. 2007. "Is the Aggregate Investor Reluctant to Realise Losses? Evidence from Taiwan." European Financial Management, 13(3), 423-47.

Barber, Brad M. and Terrance Odean. 2001. "Boys Will Be Boys: Gender, Overconfidence, and Common Stock Investment." Quarterly Journal of Economics, 116(1), 261-92.

. 1999. "The Courage of Misguided Convictions." Financial Analysts Journal, 55(6), 41.

87. 2002. "Online Investors: Do the Slow Die First?" Review of Financial Studies, 15(2), 455-

2000. "Trading Is Hazardous to Your Wealth: The Common Stock Investment Performance of Individual Investors." Journal of Finance, 55(2), 773-806.

Bauer, R.; N. Guenster and R. Otten. 2004. "Empirical Evidence on Corporate Governance in Europe: The Effect on Stock Returns, Firm Value, and Performance." Journal of Asset Management, 5, 91-104.

Bauer, Rob; Piet Eichholtz and Nils Kok. 2010a. "Corporate Governance and Performance: The Reit Effect." Real Estate Economics, 36(1), 1-29.

Bauer, Rob; Piet Eichholtz; Nils Kok and Paulo Peneda. 2010b. "Environmental Performance: A Global View on Commercial Real Estate," E. C. f. C. Engagement, Maastricht: Maastricht University,

Bauer, Rob; Piet M. Eichholtz; Nils Kok and John M. Quigley. 2011. "How Green Is Your Property Portfolio? The Global Real Estate Sustainability Benchmark." Rotman International Journal for Pension Management, 4(1), 34-43.

Bauer, Rob; Bart Frijns; Roger Otten and Alireza Tourani-Rad. 2008. "The Impact of Corporate Governance on Corporate Performance: Evidence from Japan. ." Pacific-Basin Finance Journal, 16(3), 236-51

Benos, Alexandros V. 1998. "Aggressiveness and Survival of Overconfident Traders." Journal of Financial Markets, 1(3-4), 353-83. 
Biais, Bruno; Denis Hilton; Karine Mazurier and Sébastien Pouget. 2005. "Judgemental Overconfidence, Self-Monitoring, and Trading Performance in an Experimental Financial Market." Review of Economic Studies, 72(2), 287-312.

Billett, Matthew T. and Yiming Qian. 2008. "Are Overconfident Ceos Born or Made? Evidence of Self-Attribution Bias from Frequent Acquirers." Management Science, 54(6), 103751.

Black, Fischer. 1986. "Noise." Journal of Finance, 41(3), 529-43.

Bonaparte, Yosef; Alok Kumar and Jeremy Page. 2010. "Political Climate, Optimism, and Investment Decisions," Working Paper.

Brounen, D.; H. Op 't Veld and V. Raitio. 2007. "Transparency in the European Non-Listed Real Estate Funds Market." Journal of Real Estate Portfolio Management, 13(2), 107-18.

Brounen, Dirk; Piet Eichholtz and David Ling. 2007. "Trading Intensity and Real Estate Performance." Journal of Real Estate Finance and Economics, 35(4), 449-74.

Campbell, L. J. 2007. "Why Would Corporations Behave in Socially Responsible Ways? An Institutional Theory of Corporate Social Responsibility." Academy of Management Review, 32, 946-67.

Campbell, R.; C. Ghosh and C. F. Sirmans. 2005. "Value Creation and Governance Structure in Reit Mergers." Journal of Real Estate Finance and Economics, 31, 225-39.

Cannon, S.E. and S.C. Vogt. 1995. "Reits and Their Management: An Analysis of Organizational Structure, Performance and Management Organization." Journal of Real Estate Research, 10, 297-317.

Capozza, Dennis R. and Paul J. Seguin. 2000. "Debt, Agency, and Management Contracts in Reits: The External Advisor Puzzle." Journal of Real Estate Finance and Economics, 20(2), 91116.

Carhart, M.M. 1997. "On Persistence in Mutual Fund Performance." Journal of Finance, 52(1), 57-82.

Chan, S.H.; W.K. Leung and K. Wang. 1998. "Institutional Investment in Reits: Evidence and Implications." Journal of Real Estate Research, 16(3), 357.

Chuang, Wen- I. and Bong-Soo Lee. 2006. "An Empirical Evaluation of the Overconfidence Hypothesis." Journal of Banking and Finance, 30(9), 2489-515.

Ciochetti, Brian A. and Mark D. McGowan. 2009. "Energy Efficiency Improvements: Do They Pay?," RERI,

Citigroup. 2006. "Real Estate Ipos: More to Come," C. G. M. E. Research, 
Core, John E.; Wayne R. Guay and Tjomme O. Rusticus. 2006. "Does Weak Governance Cause Weak Stock Returns? An Examination of Firm Operating Performance and Investors' Expectations." Journal of Finance, 61(2), 655-87.

Crane, Alan D. and Jay C. Hartzell. 2008. "Is There a Disposition Effect in Corporate Investment Decisions: Evidence from Real Estate Investment Trusts." Working Paper.

Cremers, .M. and V.B. Nair. 2005. "Governance Mechanisms and Equity Prices." Journal of Finance, 60(6), 2859-94.

De Long, J. Bradford; Andrei Shleifer; Lawrence H. Summers and Robert J. Waldmann. 1991. "The Survival of Noise Traders in Financial Markets." Journal of Business, 64(1), 1-19.

Derwall, J.; N. Guenster; R. Bauer and K. Koedijk. 2005. "The Eco-Efficiency Premium Puzzle." Financial Analysts Journal, 61(2), 51-63.

Di Giuli, Alberta and Leonard Kostovetsky. 2011. "Are Red or Blue Companies More Likely to Go Green? Politics and Corporate Social Responsibility," Working Paper.

Drobetz, W.; A. Schillhofer and H. Zimmermann. 2004. "Corporate Governance and Expected Stock Returns: Evidence from Germany." European Financial Management, 10(2), 267-93.

Eichholtz, Piet and N. Kok. 2007. "The Eu Reit and the Internal Market for Real Estate," E. P. Federation, Brussels:

Eichholtz, Piet and Nils Kok. 2008. "How Does the Market for Corporate Control Function for Property Companies?" Journal of Real Estate Finance and Economics, 36(2), 141-63.

Eichholtz, Piet; Nils Kok and John M. Quigley. 2010. "Doing Well by Doing Good: Green Office Buildings." American Economic Review, 100(5), 2494-511.

. in press. "The Economics of Green Building." Review of Economics and Statistics.

Eichholtz, Piet; Nils Kok and Erkan Yönder. 2013. "Political Preferences and Corporate Sustainability: Evidence from Reits," Working Paper.

. 2012. "Portfolio Greenness and the Financial Performance of Reits." Journal of International Money and Finance, 31(7), 1911-29.

eds. 2011. Real Estate, Governance, and the Global Economic Crisis. University of Pennsylvania Press.

Eichholtz, Piet and Erkan Yönder. 2012. "Ceo Overconfidence, Corporate Investment Activity, and Performance: Evidence from Reits," Working Paper.

Enkvist, Per-Anders; Thomas Naucler and Jerker Rosander. 2007. "A Cost Curve for Greenhouse Gas Reduction." The McKinsey Quarterley, 1, 35-45.

EPRA. 2011. "Global Reit Survey 2011," 


\section{REFERENCES}

Fama, E.F. and K.R. French. 1993. "Common Risk Factors in the Returns on Stocks and Bonds." Journal of Financial Economics, 33(1), 3-56.

Feng, Z.; C. Ghosh and C. F. Sirmans. 2005. "How Important Is the Board of Directors to Reit Performance?" Journal of Real Estate Portfolio Management, 11(3), 281-93.

Frank, T. 2012. "In U.S. Building Industry, Is It Too Easy to Be Green?," USA Today:

Fuerst, F. and P. McAllister. 2011. "Green Noise or Green Value? Measuring the Effects of Environmental Certification on Office Values." Real Estate Economics, 39(1), 45-69.

Geltner, David; Jim Clayton; Piet Eichholtz and Norman G. Miller. 2013. Commercial Real Estate Analysis and Investments. South-Western Educational Publications.

Gervais, Simon and Terrance Odean. 2001. "Learning to Be Overconfident." Review of Financial Studies, 14(1), 1-27.

Ghosh, C. and C. F. Sirmans. 2003. "Board Independence, Ownership Structure and Performance: Evidence from Real Estate Investment Trusts." Journal of Real Estate Finance and Economics, 26(2-3), 287-318.

Glaser, Markus and Martin Weber. 2007. "Overconfidence and Trading Volume." GENEVA Risk and Insurance Review, 32(1), 1-36.

Gompers, P.A.; J. Ishii and A. Metrick. 2003. "Corporate Governance and Equity Prices." Quarterly Journal of Economics, 118(1), 107.

Han, Bing. 2006. "Insider Ownership and Firm Value: Evidence from Real Estate Investment Trusts." Journal of Real Estate Finance and Economics, 32(4), 471-93.

Hansen, L. P.; J. Heaton and A. Yaron. 1996. "Finite Sample Properties of Some Alternative Gmm Estimators." Journal of Business and Economic Statistics, 14(3), 262-80.

Hartzell, Jay C.; Jarl G. Kallberg and Crocker H. Liu. 2008. "The Role of Corporate Governance in Initial Public Offerings: Evidence from Real Estate Investment Trusts." Journal of Law and Economics, 51, 539-62.

Hartzell, Jay C.; Libo Sun and Sheridan Titman. 2006. "The Effect of Corporate Governance on Investment: Evidence from Real Estate Investment Trusts." Real Estate Economics, 34(3), 343-76.

Hirshleifer, David and Guo Ying Luo. 2001. "On the Survival of Overconfident Traders in a Competitive Securities Market." Journal of Financial Markets, 4(1), 73-84.

Hong, H. and L. Kostovetsky. 2012. "Red and Blue Investing: Values and Finance." Journal of Financial Economics, 103, 1-19.

Howe, John S. and James D. Shilling. 1990. "Reit Advisor Performance." American Real Estate and Urban Economics Association Journal, 18(4), 479-500. 
Hutton, I.; J. Danling and A. Kumar. 2011. "Corporate Policies of Republican Managers," Working Paper.

Jensen, M.C. 1986. "Agency Costs of Free Cash Flow, Corporate Finance, and Takeovers." American Economic Review, 76(2), 323-29.

Johnson, Shane A.; Theodore C. Moorman and Sorin Sorescu. 2009. "A Reexamination of Corporate Governance and Equity Prices." Review of Financial Studies, 22(11), 4753-86.

Kahneman, Daniel and Amos Tversky. 1979. "Prospect Theory: An Analysis of Decision under Risk." Econometrica, 47(2), 263-91.

Karafiath, Imre. 1994. "On the Efficiency of Least Squares Regression with Security Abnormal Returns as the Dependent Variable." Journal of Financial and Quantitative Analysis, 29(2), 279300

Kats, G. 2003. "Green Buildings Costs and Financial Benefits," Boston: Massachusetts Technology Collaborative,

Kaustia, Markku and Sami Torstila. 2011. "Stock Market Aversion? Political Preferences and Stock Market Participation." Journal of Financial Economics, 100(1), 98-112.

Kleibergen, F. and R. Paap. 2006. "Generalized Reduced Rank Tests Using the Singular Value Decomposition." Journal of Econometrics, 133, 97-126.

Kok, Nils; Rob Bauer and Piet Eichholtz. 2011a. "Gresb Research Report," E. C. f. C. Engagement, Maastricht: Maastricht University,

Kok, Nils and Maarten G. J. Jennen. 2011. "The Value of Energy Labels in the European Office Market," Unpublished,

Kok, Nils; Marquise McGraw and John M. Quigley. 2011b. "The Diffusion of Energy Efficiency in Building." American Economic Review, 101(3), 77-82.

La Porta, Rafael; Florencio Lopez-De-Silanes; Andrei Shleifer and Robert Vishny. 2000. "Agency Problems and Dividend Policies around the World." Journal of Finance, 55(1), 133.

Lehman, Robert and Howard Roth. 2012. "Global Perspectives 2012 Reit Report," Ernst and Young,

Lev, Baruch; Christine Petrovits and Suresh Radhakrishnan. 2010. "Is Doing Good Good for You? How Corporate Charitable Contributions Enhance Revenue Growth." Strategic Management Journal, 31, 182-200.

Ling, D.C. and M. Ryngaert. 1997. "Valuation Uncertainty, Institutional Involvement, and the Underpricing of Ipos: The Case of Reits." Journal of Financial Economics, 43(3), 433-56.

Malmendier, Ulrike and Geoffrey Tate. 2005a. "Ceo Overconfidence and Corporate Investment." Journal of Finance, 60(6), 2661-700. 


\section{REFERENCES}

. 2005b. "Does Overconfidence Affect Corporate Investment? Ceo Overconfidence Measures Revisited." European Financial Management, 11(5), 649-59.

. 2008. "Who Makes Acquisitions? Ceo Overconfidence and the Market's Reaction." Journal of Financial Economics, 89(1), 20-43.

Malmendier, Ulrike; Geoffrey Tate and Jon Yan. 2011. "Overconfidence and Early-Life Experiences: The Effect of Managerial Traits on Corporate Financial Policies." Journal of Finance, 66(5), 1687-733.

Margolis, J. D. and J.P. Walsh. 2001. People and Profits?: The Search for a Link between a Company's Social and Financial Performance.

Margolis, J.D. and J.P. Walsh. 2003. "Misery Loves Company: Rethinking Social Initiatives by Business." Administrative Science Quarterly, 48(2), 268-305.

Margolis, Joshua D.; Hillary A. Elfenbein and James P. Walsh. 2007. "Does It Pay to Be Good? A Meta-Analysis and Redirection of Research on the Relationship between Corporate Social and Financial Performance," Working Paper, Ross School of Business University of Michigan,

Menkhoff, Lukas and Marina Nikiforow. 2009. "Professionals' Endorsement of Behavioral Finance: Does It Impact Their Perception of Markets and Themselves?" Journal of Economic Behavior and Organization, 71(2), 318-29.

Miller, N.; J. Spivey and A. Florance. 2008. "Does Green Pay Off?" Journal of Real Estate Portfolio Management, 14(4), 385-400.

Mitton, Todd. 2002. "A Cross-Firm Analysis of the Impact of Corporate Governance on the East Asian Financial Crisis." Journal of Financial Economics, 64(2), 215-41

Odean, Terrance. 1998a. "Are Investors Reluctant to Realize Their Losses?," Journal of Finance. 1775-98. . 1999. "Do Investors Trade Too Much?" American Economic Review, 89(5), 1279-98.

. 1998b. "Volume, Volatility, Price, and Profit When All Traders Are above Average." Journal of Finance, 53(6), 1887-934.

Orlitzky, M.; F.L. Schmidt and S.L. Rynes. 2003. "Corporate Social and Financial Performance: A Meta-Analysis." Organization Studies, 24(3), 403-41.

Papke, Leslie E. and Jeffrey M. Wooldridge. 1996. "Econometric Methods for Fractional Response Variables with an Application to 401(K) Plan Participation Rates." Journal of Applied Econometrics, 11, 619-32.

Petersen, Mitchell A. 2009. "Estimating Standard Errors in Finance Panel Data Sets: Comparing Approaches." Review of Financial Studies, 22(1), 435-80. 
Peterson, J.D. and C. Hsieh. 1997. "Do Common Risk Factors in the Returns on Stocks and Bonds Explain Returns on Reits?" Real Estate Economics, 25(2), 321-45.

Pivo, Gary. 2008. "Exploring Responsible Property Investing: A Survey of American Executives." Corporate Social Responsibility and Environmental Management, 15(4), 235-48.

Rajan, Raghurham and Luigi Zingales. 1998. "Which Capitalism? Lessons from the East Asian Crisis." Journal of Applied Corporate Finance, 11(3).

Ribstein, Larry E. 2005. "Sarbanes-Oxley after Three Years," University of Illinois Legal Working Paper Series.

RICS. 2005. "Green Value," London and Vancouver: RICS,

Roll, Richard. 1986. "The Hubris Hypothesis of Corporate Takeovers." Journal of Business, 59(2), 197-216.

Shefrin, Hersh and Meir Statman. 1985. "The Disposition to Sell Winners Too Early and Ride Losers Too Long: Theory and Evidence." Journal of Finance, 40(3), 777-90.

Turban, D.B. and D.W. Greening. 1997. "Corporate Social Performance and Organizational Attractiveness to Prospective Employees." Academy of Management Journal, 40(3), 658-72.

Waddock, S.A. and S.B. Graves. 1997. "The Corporate Social Performance-Financial Performance Link." Strategic Management Journal, 18(4), 303-19.

Wang, K.; J. Erickson; G. Gau and S.H. Chan. 1995. "Market Microstructure and Real Estate Returns." Real Estate Economics, 23(1), 85-100.

White, Halbert. 1980. "A Heteroskedasticity-Consistent Covariance Matrix Estimator and a Direct Test for Heteroskedasticity." Econometrica, 48(4), 817-38.

Wiley, J. A.; Justin D. Benefield and Ken H. Johnson. 2008. "Green Design and the Market for Commercial Office Space " Journal of Real Estate Finance and Economics, 41(2), 228-43.

Zivot, Eric and Donald W.K. Andrews. 1992. "Further Evidence on the Great Crash, the OilPrice Shock, and the Unit-Root Hypothesis." Journal of Business and Economic Statistics, 10(3), 251-70. 


\section{Samenvatting (Summary in Dutch)}

In de afgelopen twee decennia is onroerend goed een belangrijk investeringsmiddel geweest in de portefeuilles van pensioenfondsen en andere institutionele investeerders wereldwijd. Real Estate Investment Trusts (REIT's) als type indirecte onroerendgoedinvesteringen hebben een cruciale rol gespeeld in deze trend en helpt investeerders de aandacht te trekken naar het onroerend goed in hun portefeuilles. REIT's zijn belastingvrij en strenger geregeld dan reguliere coöperaties. Ze moeten zich aan bepaalde regels houden en om hun REIT-status en belastingvrijstelling te behouden, kunnen ze in vier categorieën geplaatst worden: eigendom, omzet, activa en distributie.

In vergelijking met reguliere coöperaties bieden REIT onderzoekers een unieke laboratoriumomgeving om investeringsbeslissingen te evalueren. Dit creëert allerlei interessante mogelijkheden voor empirisch onderzoek vanwege de strenge wettelijke regels die ze hanteren. Dit proefschrift onderzoekt slechts enkele op het gebied van corporate governance, behavioral finance en MVO.

In Hoofdstuk 2 onderzoek ik los van elkaar het effect van de mate van corporate governance op de aandelenprestatie van de REIT tijdens de bloeien crisistijd van onroerend goed in de laatste tien jaar. Ik ontdek geen impact van corporate governance praktijken op de aandelenprestatie van de REIT's wat betreft de pre-crisis periode. Aan de andere kant verwerken (institutionele) investeerders tijdens de financiële crisis wel degelijk informatie betreffende de sterkte van corporate governance in hun besluitvormend proces met betrekking tot investeren. Mijn resultaten tonen aan dat beter bestuurde bedrijven hun slechter bestuurde tegenhangers overtreffen.

Ik concludeer ook een positief effect van institutioneel eigendom op abnormale winst en een convexe verhouding tussen de executive eigendom en abnormale winst. Het gevolg voor de onroerendgoedvoorraad van institutionele investeerders wijst erop dat institutionele eigenaren significante invloed hebben op indirecte onroerendgoedmarkten, terwijl ze niet direct onroerend goed bezitten.

In Hoofdstuk 3 onderzoek ik of een overmoedige REIT manager meer investeert dan zijn niet overmoedige tegenhanger. De mate van 
zelfvertrouwen meet ik aan de hand van gegevens over werknemersopties en handel met voorkennis door de CEO's van de REIT's. Gezien ik gedetailleerde gegevens heb over de acquisitie en verkoop van onroerend goed van REIT, kan ik de impact van een overmoedige CEO op acquisitie en bezit evalueren en afzonderlijk testen of acquisitie- en verkoopactiviteiten verschillen op dit gebied.

De resultaten tonen aan dat als ze voldoende beschikbaar geld hebben, de overmoedige REIT managers inderdaad meer investeren dan hun niet overmoedige tegenhangers. De bevindingen van de acquisitie- en verkoopactiviteiten tonen afzonderlijk aan dat overmoedige CEO's meer kopen en minder verkopen met het toegewezen beschikbare geld dan hun niet overmoedige tegenhangers. Dienovereenkomstig concludeer ik dat overmoedige CEO's slechter presteren, dus handel met voorkennis is inderdaad een volmacht voor een te groot zelfvertrouwen en niet voor waardevolle onderhandse informatie. Voor zover ik weet is dit het eerste onderzoek dat het effect aantoont van te veel zelfvertrouwen op de onroerendgoedmarkt.

In Hoofdstuk 4 evalueer ik de factoren die groene onroerendgoedinvesteringen beïnvloeden. Ik stel de hypothese dat REIT's waarvan de CEO's meer aan de Democraten bijdragen tijdens de federale verkiezingen eerder een groenere portefeuille hebben dan Republikeinsgeoriënteerde managers, bij wie een groene portefeuille gedefinieerd wordt als het aandeel in door LEED of Energy Star gecertificeerd onroerend goed binnen de REIT onroerendgoedportefeuilles. Mijn hoofdhypothese is gebaseerd op twee ideeën. Ten eerste zijn Democraten gevoeliger voor het volgen van milieubeleid en ten tweede neigen Republikeinen eerder naar conservatief en zijn over het algemeen onwilliger om risicovolle investeringen te doen.

Tijdens het verzamelen van gegevens over de bijdragen van de REIT CEO's aan kandidaten tijdens federale verkiezingen, concludeer ik dat naar Democraten neigende (Republikeinse) CEO's eerder (minder) een groenere portefeuille hebben dan gemeten aan de hand van aanwezigheid van gebouwen met Energy Star labels. Ik vind geen verband tussen de politieke voorkeur van een REIT CEO en de groenheid van de portefeuille aan de hand van gemeten door LEED labels. Deze bevindingen dragen bij aan de publieke discussie van LEED en Energy Star certificeringen. Ik toon ook aan dat de grootte van de firma, de plaatselijke groenheid van een gebouw en 
de ervaring van de CEO signifant de groenheid van de portefeuille beïnvloeden.

Door het effect van een groene portefeuille op het bedrijfs- en aandelenresultaat van de REIT's te evalueren, krijgen we inzicht in het resultaat van de interactie tussen de kosten en baten van groene onroerendgoedinvesteringen. Dit leidt tot de literatuur en vergroot ons begrip van het netto voordeel van groene onroerendgoedinvesteringen.

In Hoofdstuk 5 documenteren we dat een groene portefeuille positief verband heeft met het bedrijfsresultaat van de REIT's, berekend aan de hand van een tweefasen-regressiemodel met twee unieke instrumentale variabelen.

Ik onderzoek ook de impact van groene portefeuilles op de aandelenprestatie van de REIT's. Mijn resultaten wijzen erop dat er geen significant verband is tussen groene portefeuilles en abnormale aandelenwinst. Investeerders verwerken dus misschien al informatie in de aandelenprijzen in de hogere geldstromen, afkomstig uit investeringen in efficiëntere eigenschappen. Beduidend concludeer ik dat groenere portefeuilles geassocieerd worden met lagere markt bèta. Dit kan verklaard worden door het feit dat REIT's met groenere portefeuilles minder blootgesteld worden aan energieprijsfluctuaties en minder gevoelig zijn voor bezettingsrisico's. 


\section{Biography}

Erkan Yönder was born on July 5, 1982 in Izmir, Turkey. He studied at Middle East Technical University, where he obtained his Bachelor of Science and Master of Science degrees in Economics.

He studied and worked as a Ph.D. candidate at the Department of Finance, at Maastricht University, the Netherlands pursuing a doctorate degree in finance.

He also visited the Center for Real Estate, the Massachusetts Institute of Technology to do research in the United States.

Several of his works have been published. His paper, "Portfolio Greenness and the Financial Performance of REITs", has been published in the Journal of International Money and Finance. Additionally, his paper, "Real Estate, Governance, and the Global Economic Crisis" has been a chapter in the book, "Corporate Governance Failures: The Role of Institutional Investors in the Global Financial Crisis" published by University of Pennsylvania Press.

He has also presented his papers in many conferences including the conference of European Real Estate Society at Bocconi University, Italy (2010), the International Conference on Real Estate Securities at Tilburg University, the Netherlands (2011), the annual meeting of the Academy of Behavioral Finance and Economics at the University of California, Los Angeles (UCLA) (2011), the fourth annual conference of the Alliance for Research on Corporate Sustainability at Yale University, New Haven (2012), the Behavioral Finance Working Group/M\&A Research Centre Conference at Cass Business School, London (2012), the ASSA meetings of the American Real Estate and Urban Economics Association (2013). His paper, "CEO Overconfidence, Corporate Investment Activity, and Performance: Evidence from REITs", has received the Best Doctorate Paper Award from the Academy of Behavioral Finance and Economics at UCLA. 